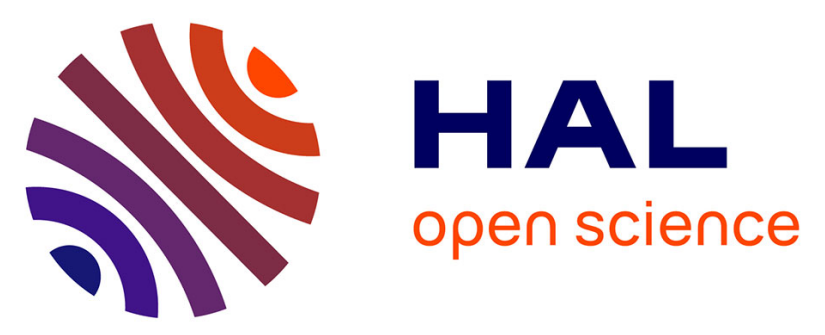

\title{
Synthesis and Properties of TRANSDIP, a Rigid Chelator Built upon a Cyclodextrin Cavity: Is TRANSDIP an Authentictrans-Spanning Ligand?
}

Laurent Poorters, Dominique Armspach, Dominique Matt, Loic Toupet, Sylvie Choua, Philippe Turek

\section{To cite this version:}

Laurent Poorters, Dominique Armspach, Dominique Matt, Loic Toupet, Sylvie Choua, et al.. Synthesis and Properties of TRANSDIP, a Rigid Chelator Built upon a Cyclodextrin Cavity: Is TRANSDIP an Authentictrans-Spanning Ligand?. Chemistry - A European Journal, 2007, 13 (34), pp.9448-9461. 10.1002/chem.200700831. hal-03034962

\section{HAL Id: hal-03034962 https://hal.science/hal-03034962}

Submitted on 1 Dec 2020

HAL is a multi-disciplinary open access archive for the deposit and dissemination of scientific research documents, whether they are published or not. The documents may come from teaching and research institutions in France or abroad, or from public or private research centers.
L'archive ouverte pluridisciplinaire HAL, est destinée au dépôt et à la diffusion de documents scientifiques de niveau recherche, publiés ou non, émanant des établissements d'enseignement et de recherche français ou étrangers, des laboratoires publics ou privés. 
Synthesis and properties of TRANSDIP, a rigid chelator built upon a cyclodextrin cavity. Is TRANSDIP an authentic trans-spanning ligand?

Laurent Poorters, ${ }^{[a]}$ Dominique Armspach, ${ }^{*[a]}$ Dominique Matt, ${ }^{*[a]}$ Loïc Toupet ${ }^{[b]}$ Sylvie Choua, ${ }^{[\mathrm{c}]}$ Philippe Turek ${ }^{[\mathrm{c}]}$

Dedicated to Professor Pierre Braunstein on the occasion of his 60th birthday 
Abstract: The $C_{2}$-symmetrical diphosphane TRANSDIP was obtained in high yield by reacting $6^{\mathrm{A}}, 6^{\mathrm{B}}, 6^{\mathrm{D}}, 6^{\mathrm{E}}$-tetramesylated, permethylated $\alpha$-cyclodextrin $\left(\alpha\right.$-CD) with $\mathrm{PPhLi}_{2}$ in excess. The double cascade cyclisation thus produced is regioselective as phosphinidene capping involves only adjacent glucose units. It is also stereospecific, both phosphorus lone pairs being orientated towards the CD axis. The restricted flexibility of the phosphorus atoms, which are part of 9-membered heterocyclic rings, is responsible for $J(\mathrm{PC})$ spin-spin couplings with the eight-bond distant $\mathrm{CH}_{2} \mathrm{OMe}$ carbon atoms of glucose units $C$ and $F$. Treatment of TRANSDIP with group 10-metal dihalides gave quantitatively square-planar chelate complexes in which a $\mathrm{M}-\mathrm{X}$ bond points towards the centre of the cavitand. The favourable P...P separation and the directional control of the phosphorus lone pairs rule out the possibility of forming binuclear complexes or higher oligomers. Further, in all the complexes, the $\mathrm{P}$ atoms are in a trans arrangement. TRANSDIP may therefore be regarded as an authentic trans-spanning diphosphane. In the complex $\left[\mathrm{NiCl}_{2} \bullet \mathbf{T R A N S D I P ]}\right.$, the cavity provides effective protection of the encapsulated $\mathrm{M}-\mathrm{X}$ bond towards nucleophilic attack by MeLi. The same complex, upon activation with methylaluminoxane, efficiently dimerises ethene and propene.

Keywords: large bite angles, cavitand, diphosphane, cyclodextrin, nickel, palladium, platinum, gold, ethene dimerisation.

[a] Dr. L. Poorters, Dr. D. Armspach, Dr. D. Matt, Laboratoire de Chimie Inorganique Moléculaire Université Louis Pasteur, Institut de Chimie UMR 7177 CNRS 1 rue Blaise Pascal, F-67008 Strasbourg Cedex France. E-mail:dmatt@chimie.u-strasbg.fr

[b] Dr. L. Toupet Université de Rennes 1 Groupe matière condensée et matériaux UMR 6626 Campus de Beaulieu, F-35042, Rennes Cedex, France

[c] Dr. S. Choua, Prof. P. Turek Laboratoire de RPE Université Louis Pasteur, Institut de Chimie UMR 7177 CNRS 1 rue Blaise Pascal, F-67008 Strasbourg Cedex France 


\section{Introduction}

Speculations began early in the $20^{\text {th }}$ century concerning the possibility of a bidentate ligand spanning opposite sites in a complex of square-planar geometry ${ }^{[1,2]}$ It was considered that a bidentate species with a link of sufficient length between the donor atoms might be suitable. However, nearly all efforts to build trans-spanned complexes led to inconclusive or negative results ${ }^{[3-8]}$ so that in the early thirties it was generally agreed that these complexes were not to be obtained simply by such means. In fact, most of the early long bidentates behaved as bridging ligands upon metal complexation, leading to coordination oligomers and polymers. ${ }^{[9]}$

The first trans-spanned diphosphane complex was eventually reported in 1961 by Issleib and Hohfeld. ${ }^{[10]}$ It consists of a simple diphosphane with a pentamethene link which formed a trans-chelate on four-coordinate nickel(II) (Figure 1). In the following years, a multitude of ligands capable of spanning metal ions in a trans fashion were studied. ${ }^{[1]}$

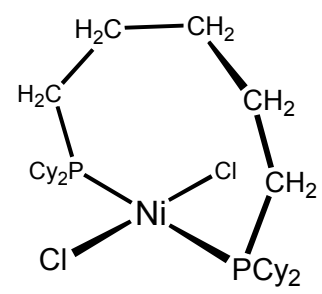

Figure 1. The first trans-spanned diphosphane complex, published by Issleib and Hohfeld in 1961. ${ }^{[10]}$

It is noteworthy that the first trans-spanned diamine complex was fully characterised in $1975,{ }^{[12]}$ although its synthesis was already reported in a Thesis published in $1946 .{ }^{[13]}$

In 1974, Venanzi and co-workers described the TRANSPHOS ligand, the first transspanning diphosphane having a rigid backbone (A, Figure 2). ${ }^{[1,15]}$ Built upon a benzo $[c]$ phenanthrene scaffold, it was said to have a consistent preference for transcoordination. ${ }^{[14,16]}$ Since then, other diphosphines conceived as trans-spanning ligands were prepared, notably Ito's ArylTRAPs $(\mathbf{B}),{ }^{[17,18]}$ van Leeuwen's XANTPHOS $(\mathbf{C})^{[19-21]}$ and SPANPHOS (D) ${ }^{[22]}$ Protasiewicz's $m$-terphenyl based pincer $\mathbf{E}^{[23]}$ and Gelman's triptycene derived bidentates $\mathbf{F}^{[24,25]}$ (Figure 2). All these diphosphanes were designed to behave as chelators capable of precluding the formation of cis complexes. It is noteworthy that genuine 
trans-spanning ligands are expected not to form bimetallic complexes or higher oligomers, in other words they should function as real chelators.

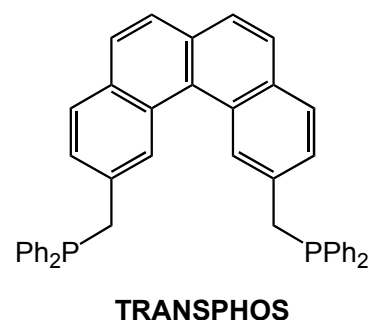

(A)

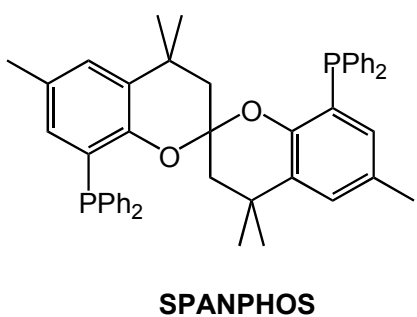

(D)

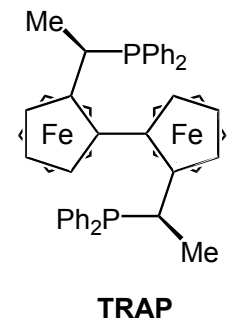

(B)

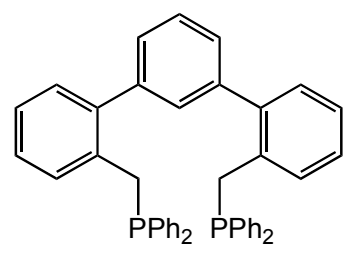

(E)<smiles>CC1(C)c2cccc(P)c2Oc2c(P)cccc21</smiles>

XANTPHOS

(C)

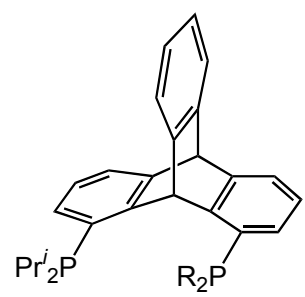

(F) $\mathrm{R}=\mathrm{Pr}^{i}, \mathrm{Ph}$

Figure 2. Some well-known trans-spanning diphosphanes from the literature.

While initial results were consistent with exclusive trans-spanning ligands, later experiments showed that all these diphosphanes still possess sufficient flexibility for chelate complexes with smaller bite angles to be formed. Some of them could even coordinate in a cis fashion. Thus, although XANTPHOS and its derivatives were originally designed as diphosphines having large bite angles, the P-M-P angles found in some of their complexes were as small as $98^{\circ}{ }^{[26-28]}$ Moreover, strongly distorted square-planar geometries around the metal centre were observed in $\left[\mathrm{PdCl}_{2}(\mathbf{F})\right]$ complexes (with P-Pd-P angles of $150^{\circ}$ and $155^{\circ}$ ), not to mention the ability of these ligands to form $P, P$-bridged dipalladium complexes. ${ }^{[24]}$ Further, treatment of TRAP with trans-[ $\left[\mathrm{PtCl}_{2}(\mathrm{MeCN})_{2}\right]$ afforded, along with the hoped-for trans complex, also the corresponding cis chelate. ${ }^{[17]}$ Likewise, about six years after their first publication dealing with TRANSPHOS, Venanzi's group had to admit that the latter also acts as cis-spanning ligand towards the $\mathrm{PtCl}_{2}$ unit. ${ }^{[29]}$ Finally, van Leeuven and co-workers recently published a paper entitled "SPANPHOS: trans-spanning diphosphines as cis-chelating ligands!", describing cationic rhodium(I)-SPANPHOS complexes with a cis configuration. ${ }^{[30]}$ Note that all of the above described diphosphines A-F were also shown to produce binuclear or oligomeric materials upon metal complexation. 
All these setbacks demonstrate the difficulty in obtaining genuine trans chelators. As a consequence, even though the advantages of such diphosphines may range from the stabilisation of exotic metal geometries to unusual selectivities in various catalytic processes, their preparation still remains a challenge.

In the following, we describe the synthesis of a large diphosphane, TRANSDIP, leading exclusively to a chelate complex when reacted with a transition metal ion able to accept two two-electron donors. TRANSDIP is based on a $\alpha$-cyclodextrin platform ( $\alpha$-CD). The synthetic strategy outlined hereafter allowed not only the positioning of the two coordinating atoms above the primary face of the $\mathrm{CD}$ macrocycle but also to control the orientation of the phosphorus lone pairs. Because of the ligand's rigidity and the appropriate phosphorus-phosphorus separation, we anticipated that this diphosphine should selectively result in complexes with trans stereochemistry when reacted with metal halides of groups IX and X. It has to be mentioned here that trans-chelating diphosphanes built upon a cavity $(e . g$. calixarenes, ${ }^{[31,32]}$ and cyclodextrins ${ }^{[33,34]}$ ) have been published previously, but all these either readily form cis-complexes or coordination oligomers. A preliminary publication on the synthesis of TRANSDIP has been published previously. ${ }^{[35]}$

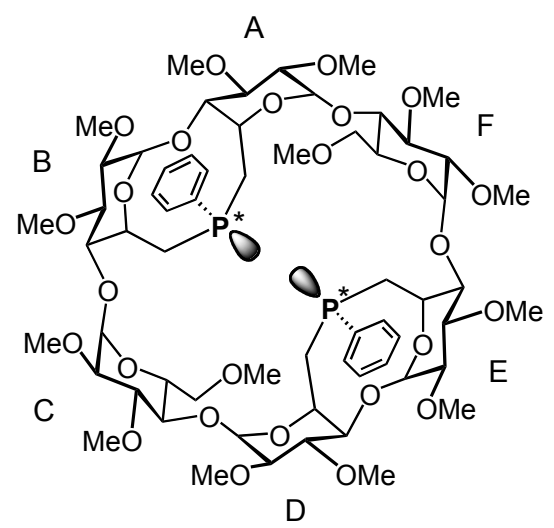

TRANSDIP 


\section{Results and Discussion}

Ligand synthesis: TRANSDIP was synthesised from the previously described tetramesylate $1^{[35]}$ by treatment with an excess of the lithiated dianion $\mathrm{PhPLi} \mathrm{i}_{2}$ at $18^{\circ} \mathrm{C}$ (Scheme 1$)$. The resulting cyclisations produced a single diastereoisomer in high yield $(>95 \%)$. The formulation of the diphosphine was inferred from its FAB mass spectrum which revealed a strong peak for the $[M+\mathrm{H}]^{+}$cation $(\mathrm{m} / z$ 1317.4). The presence of three doublets for the $\mathrm{H}-1$

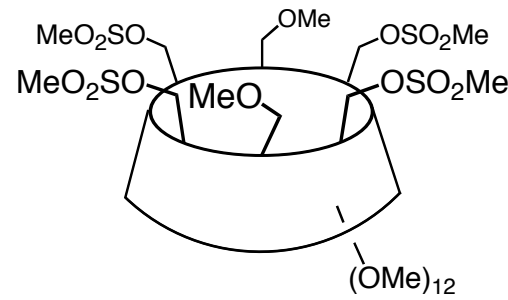

1

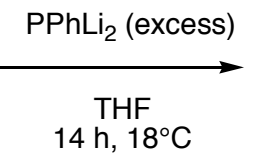

$14 \mathrm{~h}, 18^{\circ} \mathrm{C}$

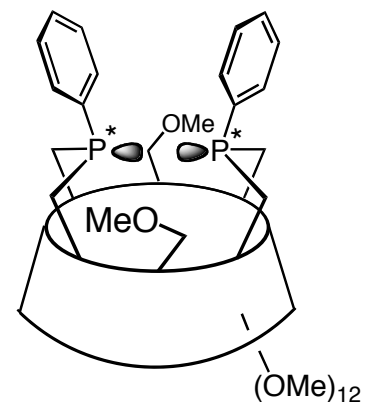

TRANSDIP

Scheme 1. Synthesis of TRANSDIP

protons and seven singlets for the methyl groups in the ${ }^{1} \mathrm{H}$ NMR spectrum is consistent with a $C_{2}$-symmetrical molecule. The signals of the anomeric protons appear in a narrow range $(\Delta \delta=0.06 \mathrm{ppm})$, hence suggesting that the CD torus underwent no significant distortion upon capping. These findings imply that bridging of adjacent glucose units is clearly favoured over $A, C$ - and $A, D$-cyclisation as well as oligomerisation, even when operating in concentrated solutions. In accord with the $C_{2}$-symmetry of the compound, the ${ }^{31} \mathrm{P}\left\{{ }^{1} \mathrm{H}\right\} \mathrm{NMR}$ spectrum shows a single peak at $-16.8 \mathrm{ppm}$. Careful examination of the ${ }^{13} \mathrm{C}$ NMR spectra (Figures 3 and 4, and SI) revealed an unexpected coupling between the phosphorus atoms and each of the symmetrically sited C- $6^{\mathrm{C}}$ and $\mathrm{C}-6^{\mathrm{F}}$ carbon atoms. The corresponding assignments were made by HMQC (see experimental section). The couplings are likely to occur via through-space interactions involving the $\mathrm{H}-6^{\mathrm{C}}, \mathrm{H}-6^{\mathrm{F}}$ hydrogen atoms and the introverted phosphorus lone pairs, as shown in Figure 5. Through-bond $J_{\mathrm{P}, \mathrm{C}-\mathrm{GC}, \mathrm{F}}$ interactions can reasonably be ruled out in view to the fact that the $\mathrm{C}-6^{\mathrm{C}, \mathrm{F}}$ carbon atoms are separated from each phosphorus atom by 8 single bonds. Note that, due to overlapping signals, the corresponding $J_{\mathrm{P}, \mathrm{H}-6}$ couplings could not be identified. Preliminary molecular mechanics calculations (MM2) reveal that in the minimised structure the $\mathrm{H}-6^{\mathrm{C}, \mathrm{F}}$ and the $\mathrm{P}$ atoms lie 
roughly in the same plane (Figure 5). We note that the $\mathrm{C}-6^{\mathrm{A}, \mathrm{B}}$ and $\mathrm{C}-6^{\mathrm{D}, \mathrm{E}}$ carbon atoms also experience couplings with both phosphorus atoms. Overall, these findings reflect the high rigidity of the two capping units.

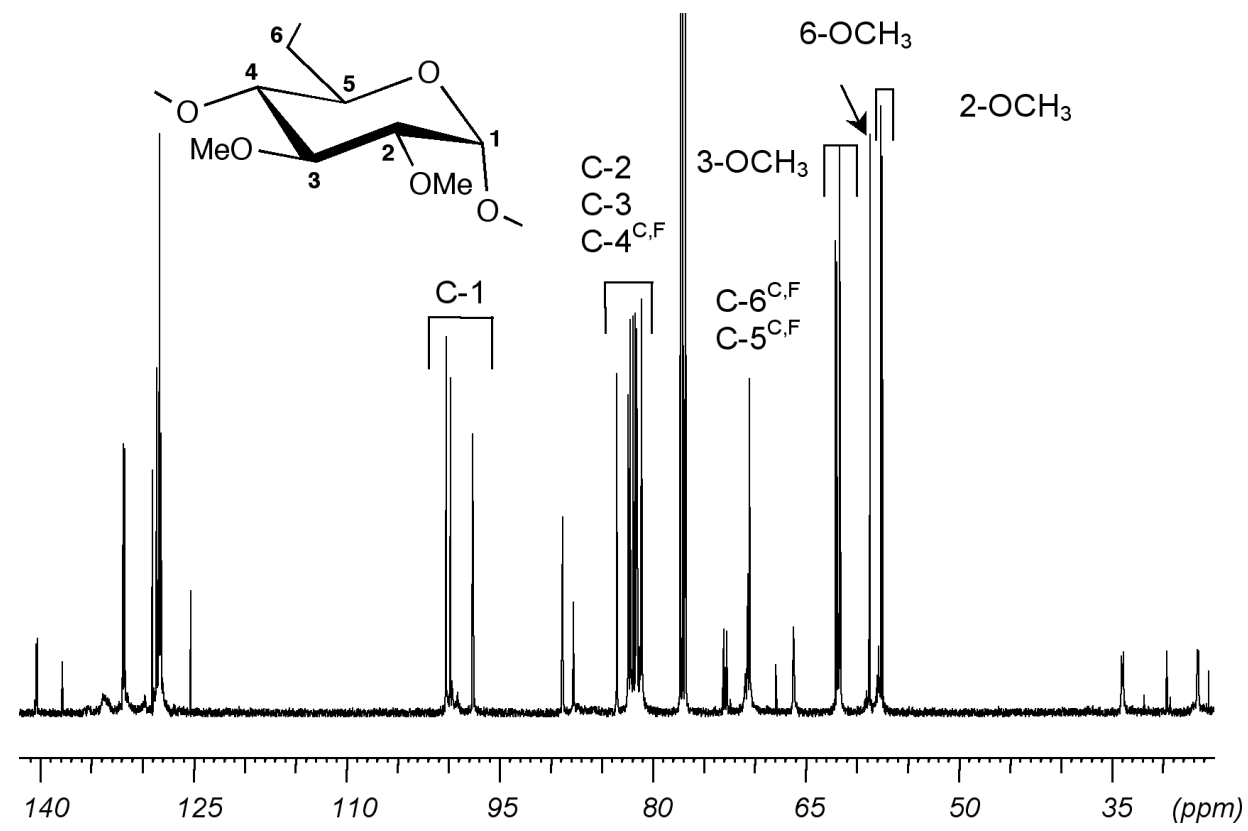

Figure 3. ${ }^{13} \mathrm{C}\left\{{ }^{1} \mathrm{H}\right\}$ NMR spectrum of TRANSDIP recorded in $\mathrm{CDCl}_{3}$ at $125.8 \mathrm{MHz}$. Enlargements are found in Fig. 4 and in the supplementary information.

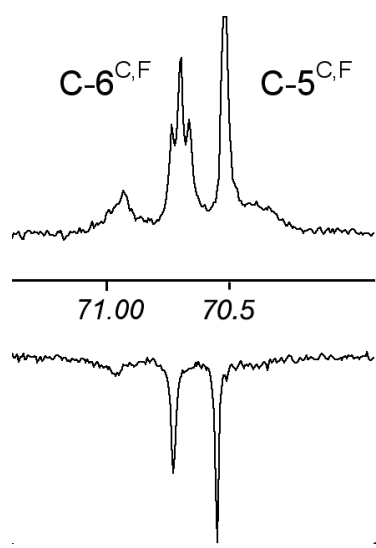

Figure 4. C- 6 , F and $\mathrm{C}-5^{\mathrm{C}, \mathrm{F}}$ signals of TRANSDIP in the ${ }^{13} \mathrm{C}\left\{{ }^{1} \mathrm{H}\right\}$ (top) and ${ }^{13} \mathrm{C}\left\{{ }^{1} \mathrm{H},{ }^{31} \mathrm{P}\right\}$ (bottom) NMR spectra recorded in $\mathrm{CDCl}_{3}$ at $125.8 \mathrm{MHz}$. 
The calculations further show that both phosphorus lone pairs of TRANSDIP point towards the cavity axis (Figure 5), resulting in rather protected $\mathrm{P}(\mathrm{III})$ centres. Consistent with this structural feature, solutions of TRANSDIP display high stability when exposed to air. The oxidised phosphine 2 was nevertheless obtained during attempts to form nickel(II) complexes in air (see experimental section). Note that reaction of TRANSDIP with $\mathrm{H}_{2} \mathrm{O}_{2}$ resulted in a mixture of unseparable compounds. On the other hand, reaction of TRANSDIP with sulfur in excess gave quantitatively the di(phosphane sulfide) 3 . When the sulfuration reaction was repeated in the presence of stoichiometric amounts of sulfur, 3 was formed as the major compound, together with small amounts of a compound, which could not be separated. In view of the ${ }^{31} \mathrm{P}$ NMR spectrum of the latter, which displays an AB spectrum $\left(\delta_{\mathrm{A}}=42.2, \delta_{\mathrm{B}}=-\right.$ $19.5, J\left(\mathrm{PP}^{\prime}\right)=48.7 \mathrm{~Hz}$ ), we assign to it the structure of monosulfide 4 (Scheme 2). In 2 as well as in 3 , the P... C- 6 (or F) couplings are lost, as revealed by the ${ }^{13} \mathrm{C}\left\{{ }^{1} \mathrm{H}\right\}$ NMR spectra in which the corresponding C-6 signal appears as singlet. As well, the C- $6^{\mathrm{A}, \mathrm{D}}$ and C- $6^{\mathrm{B}, \mathrm{E}}$ carbon atoms give rise to well-resolved doublets in the ${ }^{13} \mathrm{C}\left\{{ }^{1} \mathrm{H}\right\} \mathrm{NMR}$ spectra $\left({ }^{1} J_{\mathrm{P}, \mathrm{C}-6}=67.0 \mathrm{~Hz}\right.$ and $67.6 \mathrm{~Hz}$ for $2 ;{ }^{1} J_{\mathrm{P}, \mathrm{C}-6}=50.8 \mathrm{~Hz}$ and $52.6 \mathrm{~Hz}$ for 3 ). These observations are a further indication of the involvement of the phosphorus lone pairs in the P-C couplings observed in TRANSDIP.
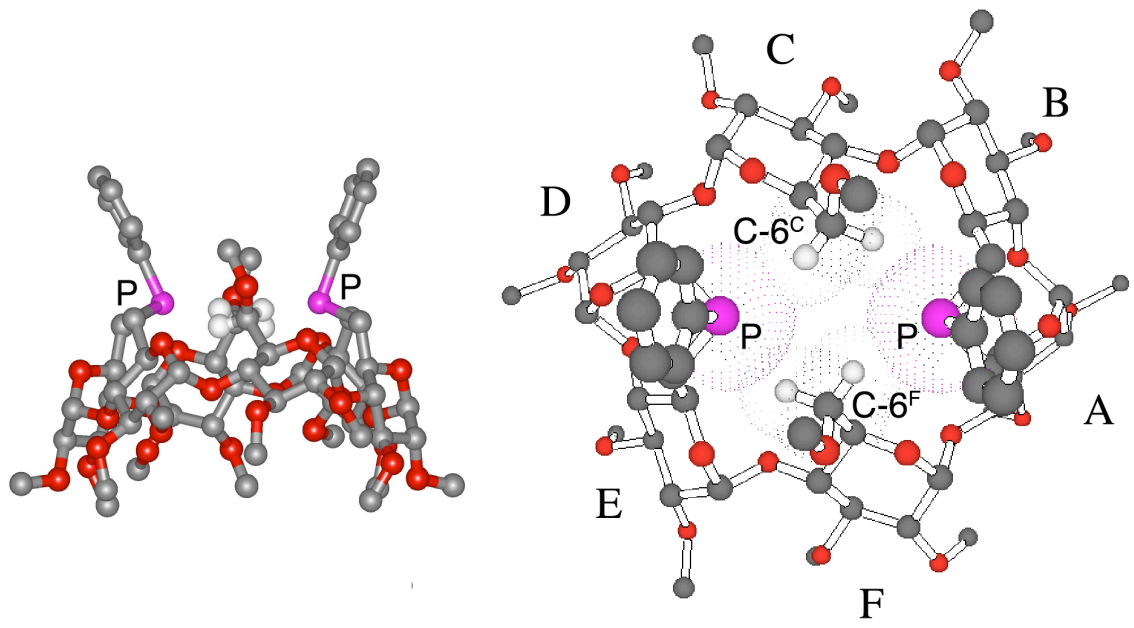

Figure 5. Calculated structure (MM2) of free TRANSDIP (right: view along the CD axis from the primary face; left, sideview). 


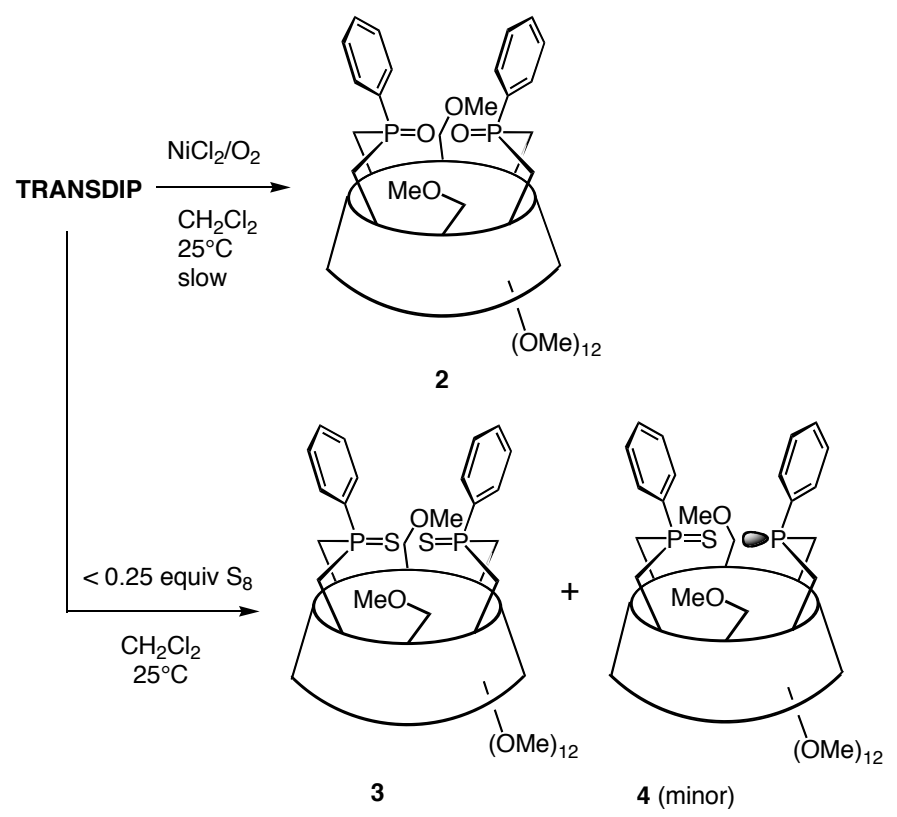

Scheme 2. Formation of P(V) derivatives of TRANSDIP.

trans-Chelating properties of TRANSDIP: According to CPK models, TRANSDIP possesses the right geometrical features to promote the formation of trans- $P, P$-chelates upon metal complexation. Evidence of the latter was given by studying the coordination of TRANSDIP towards various $\mathrm{d}^{8}$ transition metal ions prone to form square-planar metal complexes. Thus, treatment of TRANSDIP with a mixture of cis and trans isomers of $\left[\mathrm{PtCl}_{2}(\mathrm{PhCN})_{2}\right]$ afforded quantitatively complex 5 (Scheme 3). It should be mentioned that this reaction takes about three days in refluxing toluene to be completed and ${ }^{31} \mathrm{P}\left\{{ }^{1} \mathrm{H}\right\} \mathrm{NMR}$ monitoring showed that neither cis nor oligomeric compounds are formed during complexation. Complex 5 is characterised by a sharp ${ }^{31} \mathrm{P}\left\{{ }^{1} \mathrm{H}\right\}$ NMR signal at $-6.5 \mathrm{ppm}$, flanked by Pt satellites with a ${ }^{1} J_{\mathrm{P}, \mathrm{Pt}}$ coupling constant $(2463 \mathrm{~Hz})$ lying in the range expected for complexes of trans stereochemistry. ${ }^{[36]}$ 


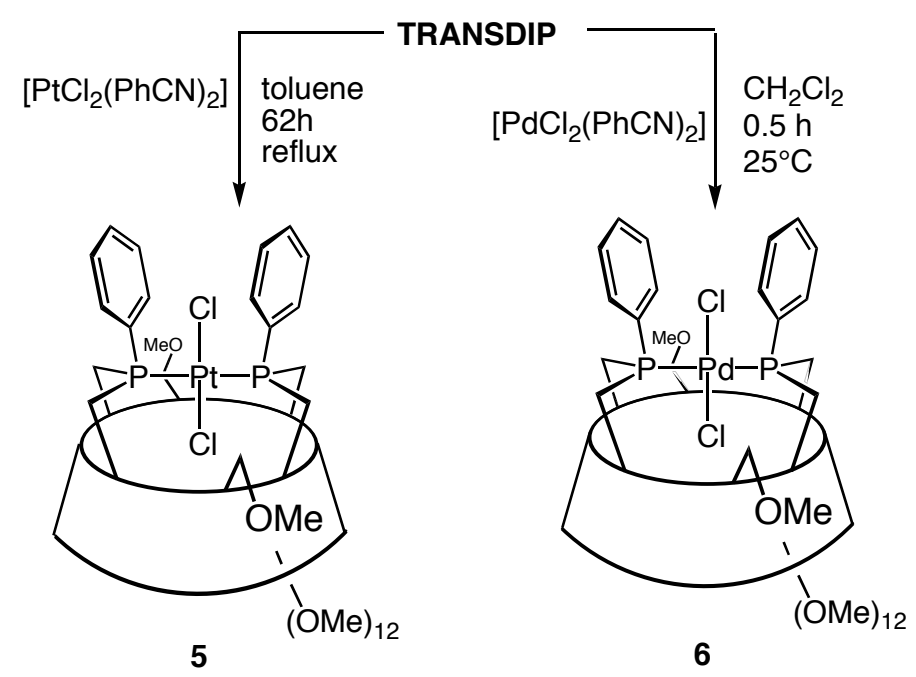

Scheme 3. Preparation of the chelate complexes 5 and $\mathbf{6 .}$

The palladium analogue 6, which was quantitatively obtained from $\left[\mathrm{PdCl}_{2}\left(\mathrm{PhCN}_{2}\right]\right.$ (Scheme 3), is characterised by a singlet at $-0.4 \mathrm{ppm}$ in the ${ }^{31} \mathrm{P}\left\{{ }^{1} \mathrm{H}\right\}$ NMR spectrum. The presence in the ${ }^{13} \mathrm{C}\left\{{ }^{1} \mathrm{H}\right\}$ NMR spectrum of a virtual triplet for each $\mathrm{PCH}_{2}$ carbon atom of the $A, D$ and $B, E$ glucose units $\left(\left|{ }^{1} J_{\mathrm{C}, \mathrm{P}}+{ }^{3} J_{\mathrm{C}, \mathrm{P}}\right|=20.0\right.$ and $25.0 \mathrm{~Hz}$, respectively) is in keeping with a trans disposition of the two phosphorus atoms. ${ }^{[37]}$ The monomeric nature of this complex was inferred from the presence of an intense signal in its mass spectrum corresponding to the $[M]^{+}$ion $(\mathrm{m} / \mathrm{z}$ 1494.1). In contrast to the demanding reaction conditions required for the preparation of 5 (see above), reaction between TRANSDIP and the palladium(II) precursor is complete within $30 \mathrm{~min}$. in $\mathrm{CH}_{2} \mathrm{Cl}_{2}$ at room temperature. As for the ligand, the ${ }^{1} \mathrm{H}$ as well as the ${ }^{13} \mathrm{C}\left\{{ }^{1} \mathrm{H}\right\}$ and ${ }^{31} \mathrm{P}\left\{{ }^{1} \mathrm{H}\right\}$ NMR spectra of complexes 5 and $\mathbf{6}$ show clear evidence for twofold molecular symmetry. The location of the chlorine atoms along the $\mathrm{CD}$ axis could be unambiguously deduced from the ${ }^{1} \mathrm{H}$ NMR spectra. The latter reveal a strong deshielding ( $>0.9 \mathrm{ppm}$ with respect to the free ligand) of two inwardly pointing H-5 atoms, indicative of weak $\mathrm{C}-\mathrm{H}^{5}$... Cl interactions (Figure 6). The H-5 atoms in question belong to phosphanesubstituted glucose units as revealed by COSY experiments. Such interactions have already been evidenced in other CDs incorporating metal chloride entities. ${ }^{[38]}$ Moreover, the phenyl groups were found to freely rotate about the P-C(aryl) axis, as evidenced by the presence of (only) two virtual triplets for the ortho- and meta-carbon atoms in the ${ }^{13} \mathrm{C}\left\{{ }^{1} \mathrm{H}\right\} \mathrm{NMR}$ spectra (see experimental section). Each triplet becomes a singlet after ${ }^{31} \mathrm{P}$ decoupling. 


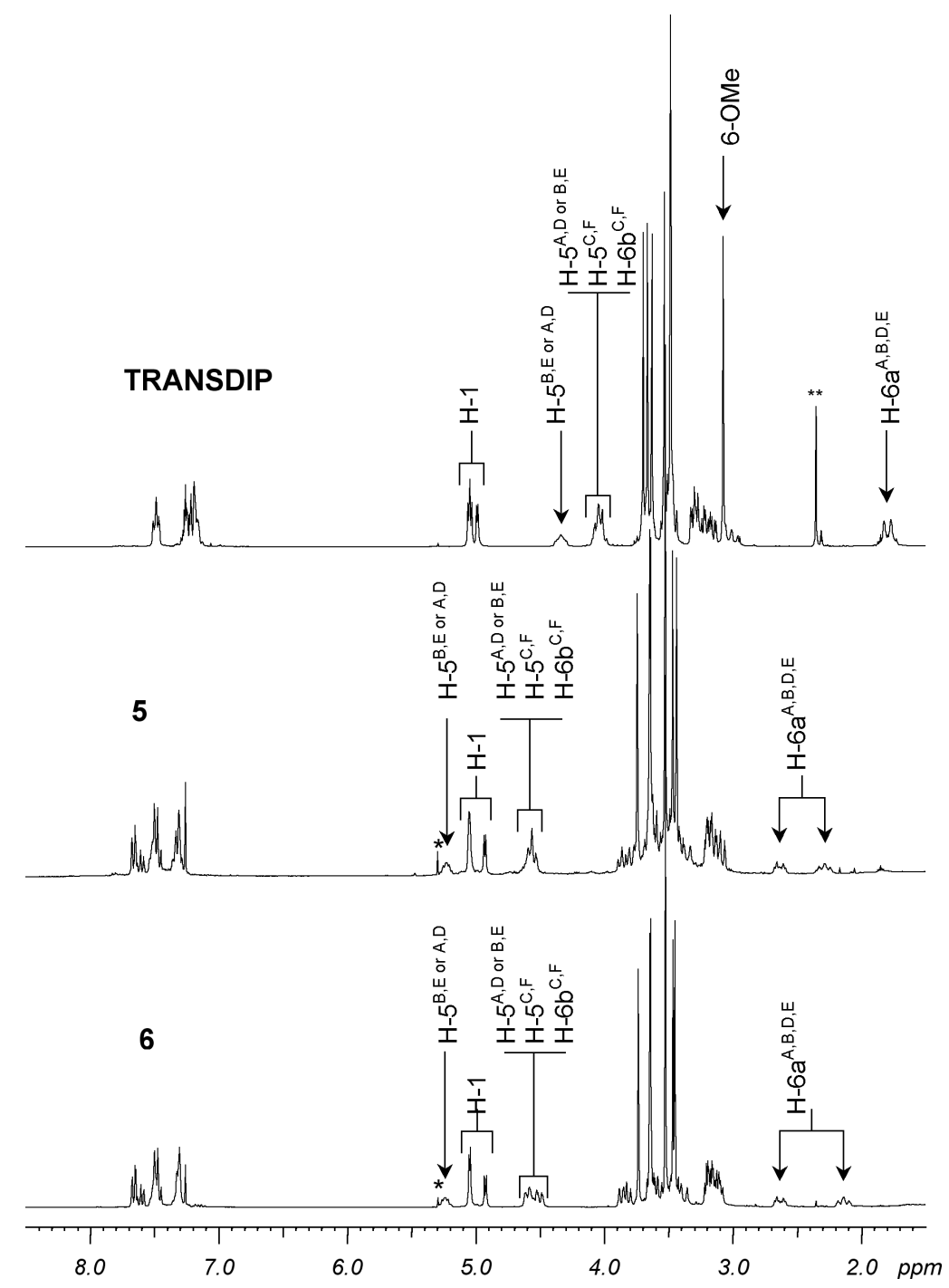

Figure 6. ${ }^{1} \mathrm{H}$ NMR spectra of TRANSDIP (top), 5 (middle), and 6 (bottom) recorded in $\mathrm{CDCl}_{3}$ at $300.1 \mathrm{MHz}$. The asterisks denote residual solvents $\left(\mathrm{CH}_{2} \mathrm{Cl}_{2}\right.$ or toluene)

An X-ray diffraction study confirmed the trans disposition of the phosphorus atoms (Figure 7 and Table 1). Note that, owing to the presence of two pentane molecules in the unit cell, the refinement of this structure did not fully converge, as frequently observed for cyclodextrins. The data are, nevertheless, provide clear information about the most important structural features of the complex. The unit cell contains two distinct molecules (denoted $a$ and $b$ ) displaying non-significant structural differences. 

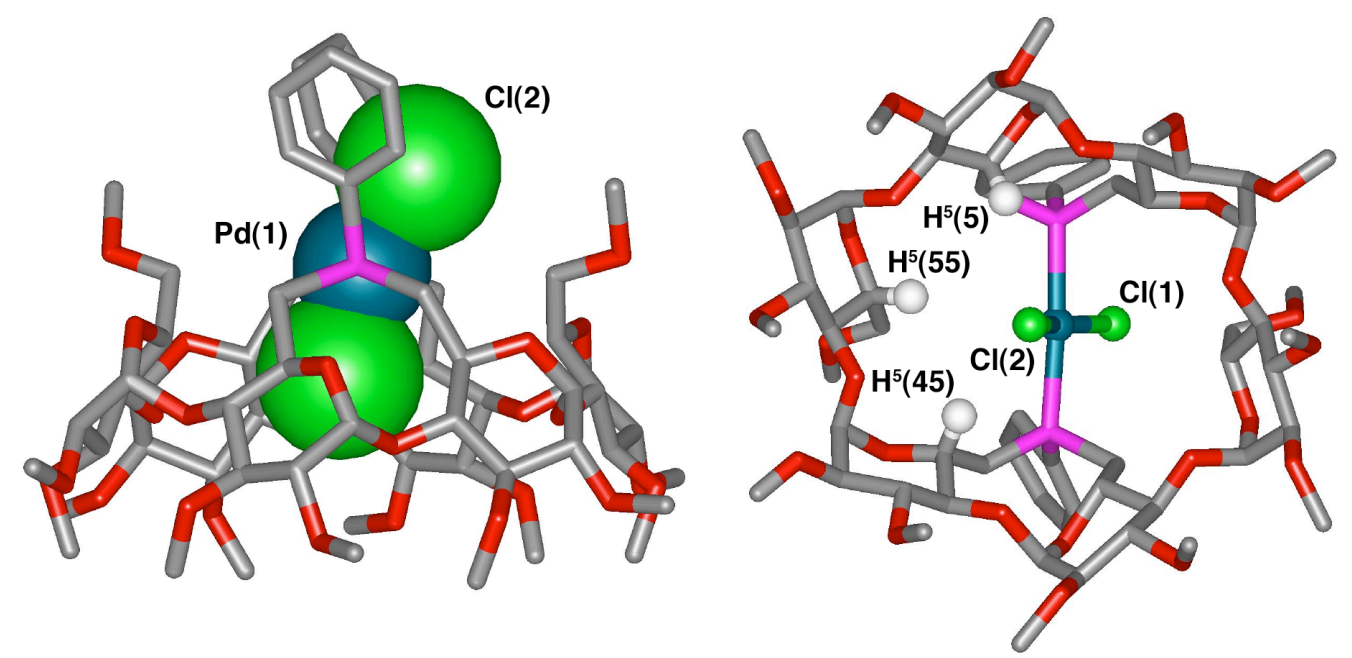

Figure 7. Molecular structure of complex 6: side view (left) and bottom view (right) showing the slightly bent Cl-Pd-Cl rod (only molecule $a$ is represented). Hydrogen atoms and solvent molecules are omitted for clarity (except three H-5 atoms).

Table 1. Selected bond lengths $(\AA)$ and angles $\left(^{\circ}\right)$ for $2(\mathbf{6}) \cdot 2\left(\mathrm{C}_{5} \mathrm{H}_{12}\right)$.

\begin{tabular}{lcccc}
\hline \multicolumn{3}{c}{ Bond lengths and distances $(\AA)$} \\
\hline \multicolumn{3}{c}{ molecule $a$} & \multicolumn{2}{c}{ molecule $b$} \\
$\mathrm{P}(1)-\mathrm{Pd}(1)$ & $2.394(5)$ & $\mathrm{P}(3)-\mathrm{Pd}(2)$ & $2.331(5)$ \\
$\mathrm{P}(2)-\mathrm{Pd}(1)$ & $2.343(5)$ & $\mathrm{P}(4)-\mathrm{Pd}(2)$ & $2.353(5)$ \\
$\mathrm{Pd}(1)-\mathrm{Cl}(1)$ & $2.271(5)$ & $\mathrm{Pd}(2)-\mathrm{Cl}(3)$ & $2.329(6)$ \\
$\mathrm{Pd}(1)-\mathrm{Cl}(2)$ & $2.337(6)$ & & $\mathrm{Pd}(2)-\mathrm{Cl}(4)$ & $2.306(5)$ \\
\cline { 5 - 6 } $\mathrm{Cl}(1)-\mathrm{H}^{5}(5)$ & 2.652 & & $\mathrm{Cl}(4)-\mathrm{H}^{5}(135)$ & 2.629 \\
$\mathrm{Cl}(1)-\mathrm{H}^{5}(55)$ & 2.852 & & $\mathrm{Cl}(4)-\mathrm{H}^{5}(125)$ & 2.747 \\
$\mathrm{Cl}(1)-\mathrm{H}^{5}(45)$ & 2.956 & & $\mathrm{Cl}(4)-\mathrm{H}^{5}(115)$ & 2.932 \\
\hline
\end{tabular}

\begin{tabular}{llll}
\hline \multicolumn{4}{c}{ Angles $\left(^{\circ}\right)$} \\
\hline \multicolumn{1}{c}{ molecule $a$} & \multicolumn{3}{c}{ molecule $b$} \\
$\mathrm{P}(1)-\mathrm{Pd}(1)-\mathrm{P}(2)$ & $174.6(2)$ & $\mathrm{P}(3)-\mathrm{Pd}(2)-\mathrm{P}(4)$ & $171.3(2)$ \\
$\mathrm{Cl}(1)-\mathrm{Pd}(1)-\mathrm{Cl}(2)$ & $162.6(3)$ & $\mathrm{Cl}(3)-\mathrm{Pd}(2)-\mathrm{Cl}(4)$ & $163.7(2)$ \\
\hline \hline
\end{tabular}

As expected, one of the chlorine atoms points towards the centre of the CD cavity, the other being exo-oriented. The shortest contacts involving the inner $\mathrm{Cl}(1)$ atom of molecule $a$ are with the $\mathrm{H}-5$ atoms $\mathrm{H}(5), \mathrm{H}(55)$ and $\mathrm{H}(45)$ (Figure 7; Cl...H-5 distances: 2.652, 2.852 and $2.956 \AA$, respectively). Similar short separations were found in molecule $b$ (Table 1). These are consistent with the previously established chlorophilicity of methylated $\alpha$-CDs. ${ }^{[34,38]}$ The stereochemistry of the palladium centre deviates in both molecules from an ideal square plane 
coordination geometry, resulting in slightly bent $\mathrm{Cl}-\mathrm{Pd}-\mathrm{Cl}$ and P-Pd-P units, but the non linearity is more marked for the $\mathrm{Cl}-\mathrm{Pd}-\mathrm{Cl}$ rods $\left(\mathrm{Cl}-\mathrm{Pd}-\mathrm{Cl}=162.6^{\circ}\right.$ and $163.7^{\circ} ; \mathrm{P}-\mathrm{Pd}-\mathrm{P}=$ $174.6^{\circ}$ and $171.3^{\circ}$ ). In fact, the observed distortion goes towards a slightly tetrahedral coordination geometry, the whole molecule being no longer $C_{2}$-symmetric. Both P-C(aryl) bonds are inclined towards one side of the $\mathrm{CD}$ torus, with the exo- $\mathrm{Cl}$ atom being obviously pushed away by the phenyl rings $\left(\mathrm{Cl}(2)-\mathrm{Pd}(1)-\mathrm{P}-\mathrm{C}(\mathrm{Ar})\right.$ torsion angles in a: 34.7 and $\left.-29.6^{\circ}\right)$. On the other hand, repulsion of the endo- $\mathrm{Cl}$ atom by the $\mathrm{CD}$ wall prevents the metal centre from adopting a perfect square-planar geometry. The apparent twofold symmetry observed in solution can be rationalised in terms of a fast oscillation of the Cl-Pd-Cl unit about the P-P axis, as shown in Figure 8. This motion could however not be frozen out on the NMR time scale on cooling a $\mathrm{CD}_{2} \mathrm{Cl}_{2}$ solution of the complex down to $-80^{\circ} \mathrm{C}$.

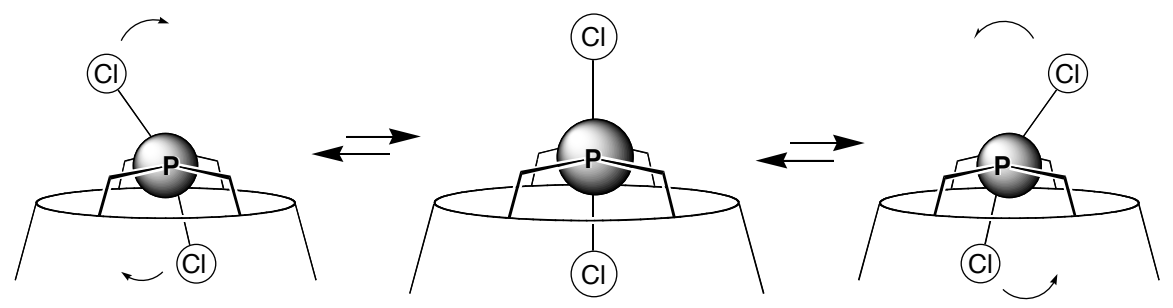

Figure 8. Proposed fast oscillation of the Cl-Pd-Cl unit about the P-P axis in complex 6.

The coordination properties of TRANSDIP were further assessed towards nickel(II) centres. Thus, the violet nickel complex 7 and the green complex 8 were quantitatively formed by reaction of TRANSDIP with $\left[\mathrm{NiCl}_{2}\right]$ and $\left[\mathrm{NiBr}_{2}\right]$, respectively (Scheme 4$)$. In both reactions a transient red species was observed, but the latter could not be isolated. The diamagnetic complexes were characterised by ${ }^{1} \mathrm{H}$ (Figure 9), ${ }^{13} \mathrm{C}\left\{{ }^{1} \mathrm{H}\right\}$ and ${ }^{31} \mathrm{P}\left\{{ }^{1} \mathrm{H}\right\}$ NMR spectroscopy, as well as MS and elemental analysis (see experimental part). The trans arrangement of the phosphorus atoms was deduced from the ${ }^{13} \mathrm{C}\left\{{ }^{1} \mathrm{H}\right\}$ NMR spectrum in which the $\mathrm{PCH}_{2}$ atoms appear as virtual triplets $\left(\left|{ }^{1} J_{\mathrm{C}, \mathrm{P}}+{ }^{3} J_{\mathrm{C}, \mathrm{P}}\right| \approx 18 \mathrm{~Hz}\right)$. 


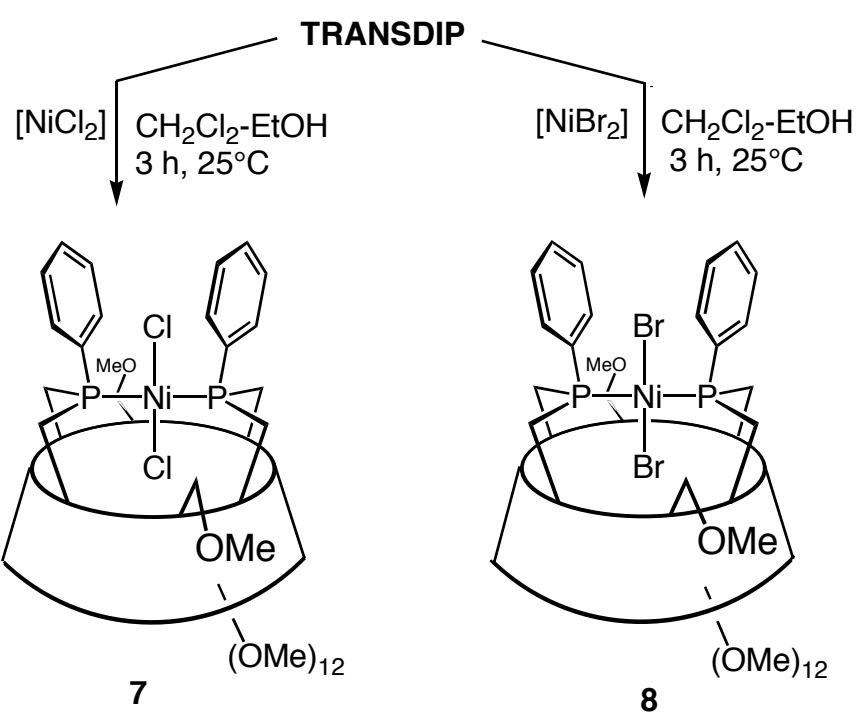

Scheme 4. Preparation of complexes 7 and $\mathbf{8}$.

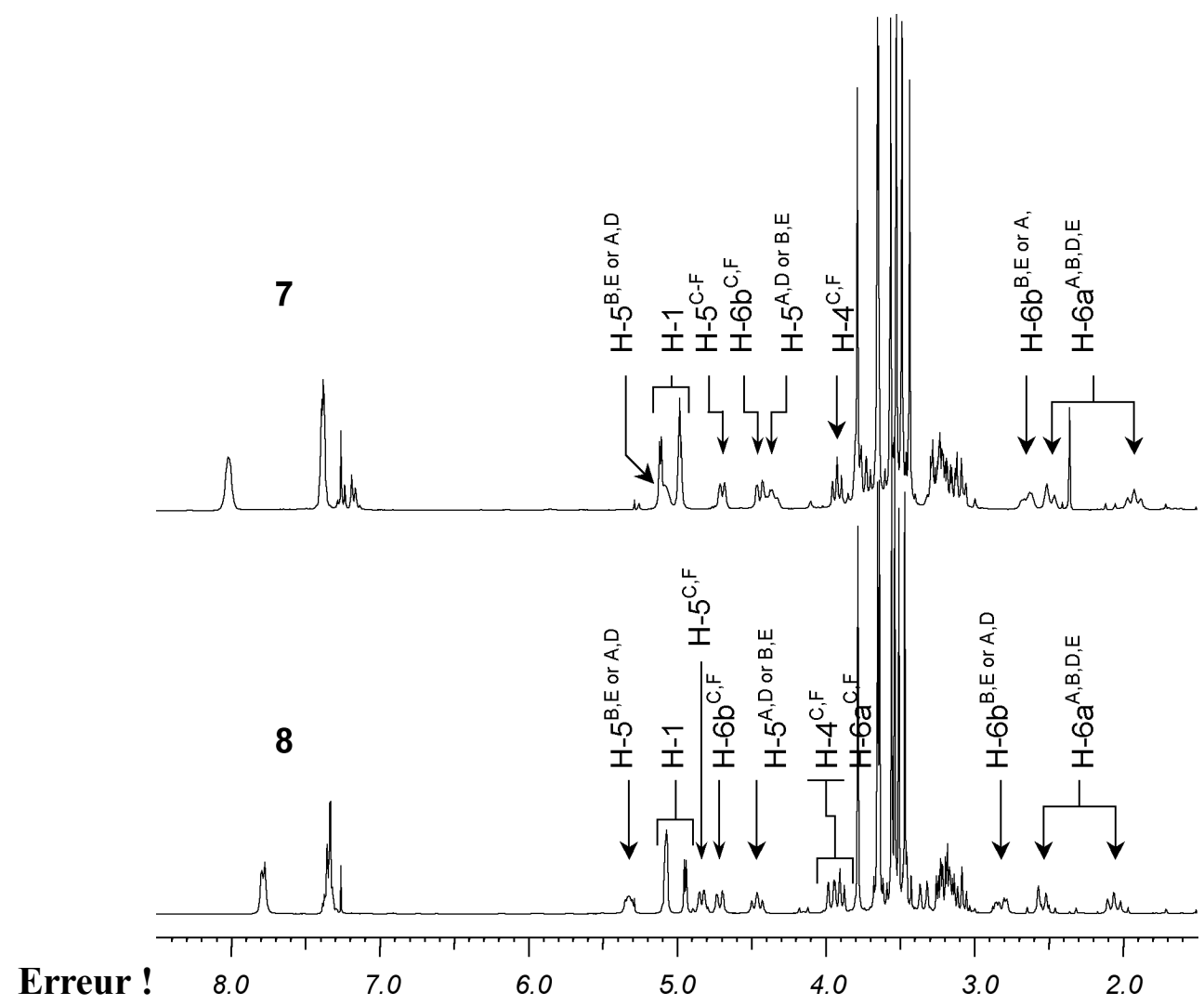

Figure 9. $\quad{ }^{1} \mathrm{H}$ NMR spectra of 7 (top) and $\mathbf{8}$ (bottom) recorded in $\mathrm{CDCl}_{3}$ at $300.1 \mathrm{MHz}$.

Finally, EPR spectroscopy measurements showed that, at temperatures as low as $4 \mathrm{~K}$, complex 8 remained diamagnetic. 
Binding properties of TRANSDIP towards unsymmetrical $\mathrm{X}-\mathrm{M}-\mathrm{Y}$ rods: Another example illustrating the trans-chelating behaviour of TRANSDIP is its reaction with [PdClMe(COD)] (COD = 1,5-cyclooctadiene) in $\mathrm{CH}_{2} \mathrm{Cl}_{2}$, leading quantitatively to complex 9 (Scheme 5). The formation of a monomeric species was inferred from the MALDI-TOF mass spectrum, which displays a peak at $m / z 1474.1$ corresponding to the $[M]^{+}$cation. Again, all NMR spectra are consistent with a $C_{2}$-symmetrical species. The trans stereochemistry was deduced from the presence of a symmetrical methyl triplet in the ${ }^{1} \mathrm{H}$ NMR spectrum $\left({ }^{3} J_{\mathrm{H}, \mathrm{P}}=\right.$ $6.8 \mathrm{~Hz}$ ). As for the previously described complexes 5-8, two H-5 protons of phosphinidenecapped glucose rings have undergone a significant lowfield shift ( $c a .1 .1 \mathrm{ppm}$ ) upon chloride encapsulation. This result is corroborated by 2D ROESY experiments, which unambiguously establish a spatial proximity between the exo-oriented methyl group and some H-6 protons as well as the PPh units.

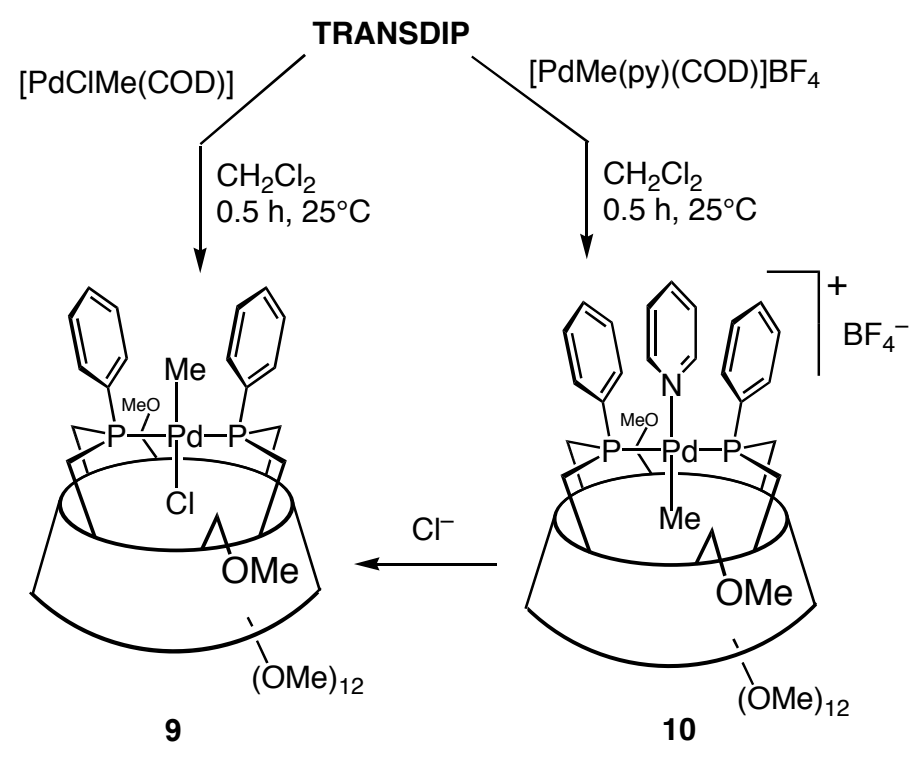

Scheme 5. Preparation of complexes 9 and $\mathbf{1 0 .}$

It must be emphasised here that, from a steric point of view the upper part of the cavity is perfectly capable of entrapping a methyl unit. This was demonstrated by treating TRANSDIP with $[\mathrm{PdMe}(\mathrm{py})(\mathrm{COD})] \mathrm{BF}_{4}(\mathrm{py}=$ pyridine $)$. This reaction resulted in the exclusive formation of trans-10 (Scheme 5), a complex with an endo-oriented Me group. Owing to the lability of the pyridine ligand, $\mathbf{1 0}$ is stable in solution only in the presence of a slight excess of pyridine. The endo orientation of the methyl group was deduced from a ROESY spectrum which showed cross peaks between the palladium-bound Me moiety and some of the inner-cavity 
CD protons. This 2D NMR experiment also revealed that the coordinated pyridine interacts with both phenyl groups. Addition of free $\mathrm{Cl}^{-}$anions to a solution of $\mathbf{1 0}$ regenerated $\mathbf{9}$, which means that in this latter reaction the Pd-Me bond is expelled from the cavity (Scheme 5).

The affinity of the CD cavity for metal bound chlorides was also exemplified by the synthesis of complex 11, obtained quantitatively by reaction of TRANSDIP with $[\mathrm{RhCl}(\mathrm{CO})(\mathrm{COD})]$ in $\mathrm{CH}_{2} \mathrm{Cl}_{2}$ (Scheme 6). The ${ }^{1} \mathrm{H}$ NMR spectrum of 11 reveals that, as expected, two symmetrically sited H-5 atoms (belonging to P-capped glucose units) are significantly downfield shifted compared to the four others, owing to weak interactions with the entrapped $\mathrm{Cl}$ atom. Attempts to replace the encapsulated $\mathrm{Cl}$ atom by a hydrido ligand by treatment of 11 with $\mathrm{NaBH}_{4}$ in ethanol produced a mixture of compounds which could not be separated. Note that entrapment of a $\mathrm{Rh}-\mathrm{H}$ bond in a $\mathrm{CD}$ cavity was achieved recently with another, more flexible, CD-derived diphosphane. ${ }^{[34]}$

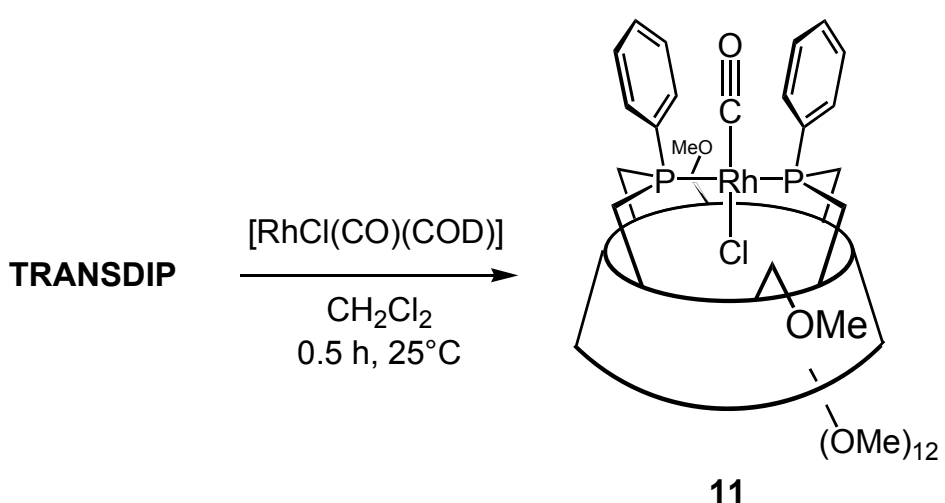

Scheme 6. Selective $\mathrm{Rh}-\mathrm{Cl}$ bond entrapment by a cyclodextrin cavity.

An interesting reaction in which the cavity behaves as a protecting funnel towards an incoming nucleophile is that between 8 and a large excess of $\mathrm{MeLi}$ in $\mathrm{Et}_{2} \mathrm{O}$ at $-78^{\circ} \mathrm{C}$ ( $\mathrm{Scheme}$ 8). This reaction gave selectively the monosubstituted derivative 12. The NMR spectrum of 12 shows a single Me signal (intensity $3 \mathrm{H}$ ), at $-0.94 \mathrm{ppm}$; a ROESY experiment confirmed the positioning of this group nearby the phenyl rings. Consistent with the presence of an unaffected $\mathrm{NiBr}$ unit lying inside the cavity, the ${ }^{1} \mathrm{H}$ NMR spectrum shows a H-5 signal (integral $2 \mathrm{H}$; protons belonging to P-capped glucose units) that has undergone a significant low-field shift with respect to that of the free ligand. The deshielding is even more pronounced than that observed for 8 (Figure 10). The reaction leading to $\mathbf{1 2}$ constitutes the first example in which a $\left[\mathrm{NiX}_{2} \mathrm{P}_{2}\right]$ complex undergoes a selective mono-alkylation, whatever the stoichiometry of alkylating agent used. ${ }^{[39]}$ In other words, the protection of the cavity is 
sufficient to prevent the substitution of the inner bromide. Interestingly, no reaction occurred when a solution of PhLi was added to $\mathbf{8}$, probably because access to the metal centre by the bulkier $\mathrm{Ph}^{-}$nucleophile is sterically hindered.
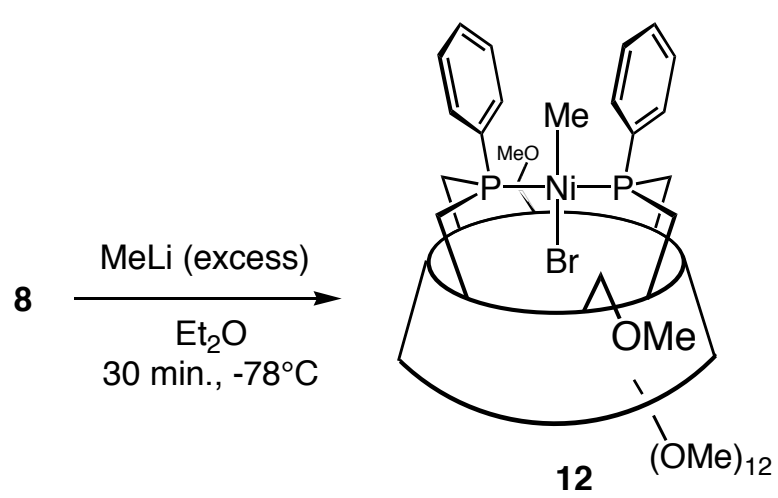

Scheme 7. A CD cavity acting as a protecting funnel towards an incoming nucleophile.

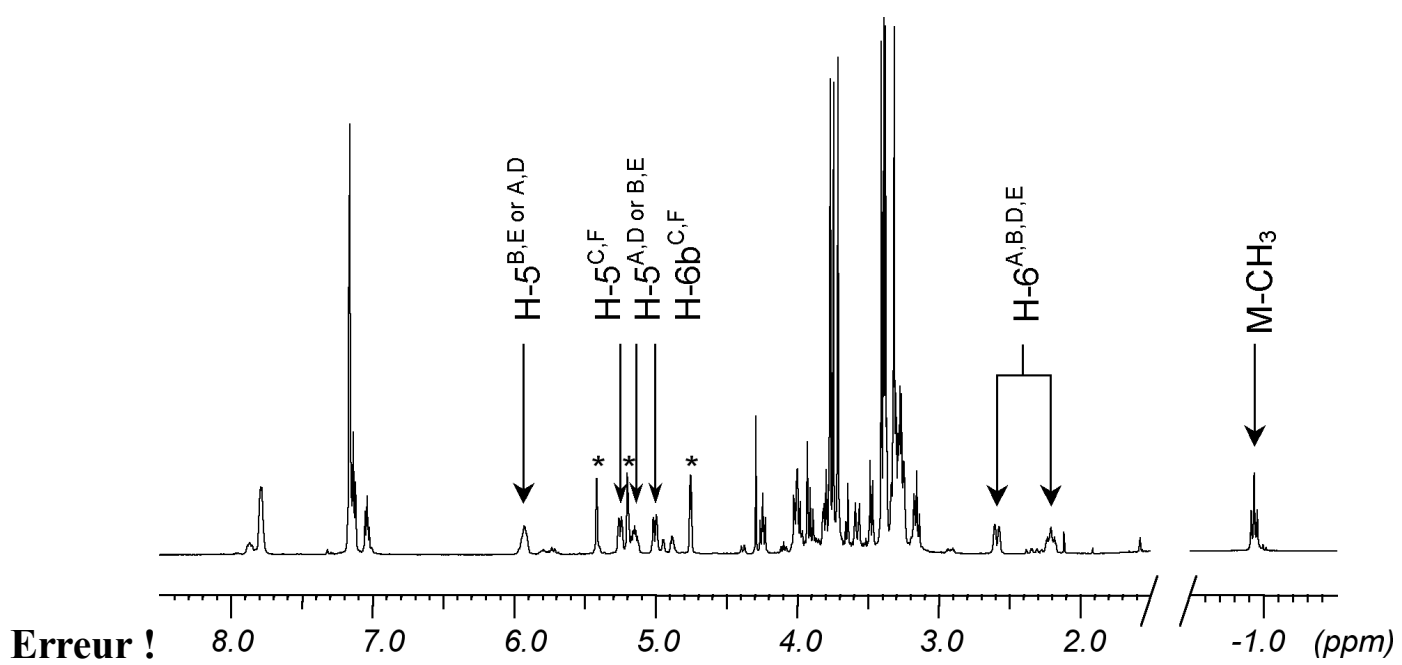

Figure 10. $\quad{ }^{1} \mathrm{H}$ NMR spectrum of 12 recorded in $\mathrm{C}_{6} \mathrm{D}_{6}$ at $500.1 \mathrm{MHz}$. The starred signals correspond to anomeric protons.

Is TRANSDIP a perfect trans chelator ? All the complexation reactions described above, which involve group 10 metal halides, are quantitative and in none of them oligomeric complexes were formed. Therefore, TRANSDIP may be regarded as an excellent chelator. Moreover, all the complexes formed display trans stereochemistry. Interestingly, the PMP angles found in $\left[\mathrm{PdCl}_{2}\right.$ (TRANSDIP)], $171.3^{\circ}$ and $174.6^{\circ}$, suggest that the natural bite angle of the ligand is somewhat smaller than $180^{\circ}$. To confirm this assumption we studied the reaction of TRANDIP with $\left[\mathrm{Au}(\mathrm{THT})\left(\mathrm{CH}_{2} \mathrm{Cl}_{2}\right)\right] \mathrm{PF}_{6}(\mathrm{THT}=$ tetrahydrothiophene), leading to 
13 (Figure 11). The $\mathrm{Au}^{+}$ion was used because of its known ability to form perfectly linear $\mathrm{P}-$ $\mathrm{Au}-\mathrm{P}$ arrangements. ${ }^{[40]}$ As for $\mathbf{6}$, the solid state structure of $\mathbf{1 3}$ reveals a non linear $\mathrm{P}-\mathrm{Au}-\mathrm{P}$ fragment, the two $\mathrm{P}-\mathrm{Au}$ vectors being somewhat bent towards the cavity centre (PAuP = $\left.163.4^{\circ}\right)$. For comparaison, a value of $175.1(1)^{\circ}$ was found in $\left[\left(\mathrm{PhMe}_{2} \mathrm{P}\right)_{2} \mathrm{Au}\right]\left[\mathrm{Au}\left(\mathrm{GeCl}_{3}\right)_{2}\right] .^{[41]}$ The $\mathrm{P}-\mathrm{Au}$ bond lengths $(2.319$ and $2.324 \AA)$ fall in the range expected for $\left.\left[\mathrm{AuPR}_{3}\right)_{2}\right]^{+}$ cations. ${ }^{[42]}$ What about the flexibility of TRANSDIP ? This question was addressed recently on studying $[\operatorname{AgX}($ TRANSDIP $)](X=$ halide $)$ chelate complexes. ${ }^{[43]}$ While PAgP angles near $120^{\circ}$ were expected for these complexes, actual values of ca. $143^{\circ}$ were found in the solid state. These observations illustrate the relatively weak flexibility of TRANSDIP, unable to accommodate an ideal trigonal planar coordination geometry. Unsurprisingly, no cis complex was formed upon reaction of TRANSDIP with $\mathrm{MX}_{2}$ moieties ( $\mathrm{M}=$ group 10 metal ions).

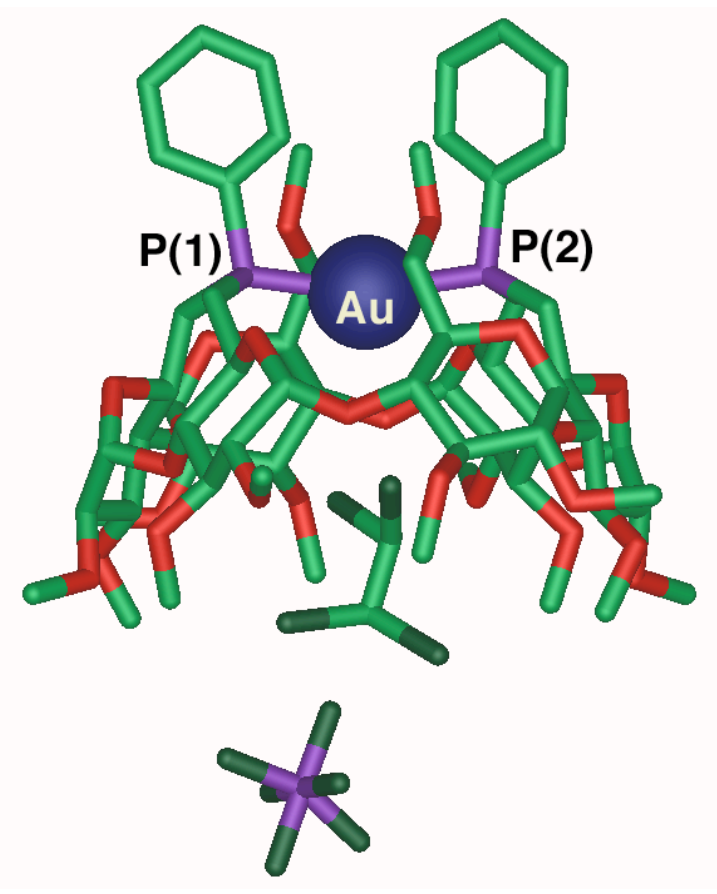

Figure 11. X-ray structure of the gold(I) complex 13. The figure shows also the $\mathrm{PF}_{6}$ anion and only one of the four $\mathrm{C}_{2} \mathrm{H}_{2} \mathrm{Cl}_{4}$ solvent molecules.

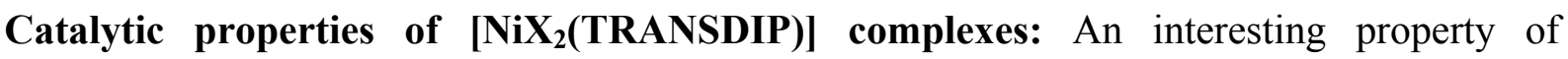
TRANSDIP concerns its catalytic properties. After activation with methylaluminoxane (MAO), the complexes 7, 8 and $\mathbf{1 2}$ catalyse the oligomerisation of ethene as well as that of propene.

Dimerisation of ethene. The ethene oligomerisation tests were carried out in toluene in a $100 \mathrm{~mL}$ steel autoclave under various conditions (Table 2). The catalytic reaction started as 
soon as an ethene pressure was applied, producing a slow but steady temperature increase over a period of $c a .1 \mathrm{~h}\left[\mathrm{P}\left(\mathrm{C}_{2} \mathrm{H}_{4}\right)=30\right.$ bar, $\left.\Delta \mathrm{T}=17-21^{\circ} \mathrm{C}\right]$, independently of the catalyst precursor used.

Table 2. Catalytic ethene dimerisation in a $100 \mathrm{~mL}$ steel autoclave. ${ }^{[\mathrm{a}]}$

\begin{tabular}{ccccccccc}
\hline Entry & $\begin{array}{c}\text { Catalyst } \\
\text { precursor }\end{array}$ & $\begin{array}{c}\mathrm{t} \\
(\mathrm{min} .)\end{array}$ & $\begin{array}{c}\mathrm{P}_{\left(\mathrm{C}_{2} \mathrm{H}_{4}\right)}(\text { bar }) \\
{[\mathrm{Al}] /[\mathrm{Ni}]}\end{array}$ & $\begin{array}{c}\mathrm{Yield}^{[\mathrm{b}]} \\
(\mathrm{g})\end{array}$ & $\begin{array}{c}\mathrm{TOF}^{[\mathrm{c}]} \\
\left(/ 10^{-4}\right)\end{array}$ & $\begin{array}{c}\text { Selectivity } \\
\mathrm{C} 4^{[\mathrm{d}]}(\mathrm{wt}-\%)\end{array}$ & $\alpha-\mathrm{C4}^{[\mathrm{e}]}$ \\
\hline 1 & {$\left[\mathrm{NiBr}_{2}\right]$} & 60 & 30 & 2000 & 0.0 & - & - & - \\
2 & {$\left[\mathrm{NiBr}_{2}(\mathrm{DME})\right]$} & 60 & 30 & 2000 & 0.0 & - & - & - \\
3 & 7 & 60 & 30 & 2000 & 4.3 & 3.4 & $>99$ & 50.0 \\
4 & $\mathbf{8}$ & 60 & 30 & 400 & 1.9 & 1.5 & $>99$ & 42.4 \\
5 & $\mathbf{8}$ & 60 & 30 & 1000 & 3.3 & 2.6 & $>99$ & 42.9 \\
6 & $\mathbf{8}$ & 60 & 30 & 2000 & 5.4 & 4.3 & $>99$ & 40.4 \\
7 & $\mathbf{8}$ & 60 & 20 & 2000 & 5.0 & 3.9 & $>99$ & 59.7 \\
8 & $\mathbf{8}$ & 60 & 10 & 2000 & 1.5 & 1.2 & $>99$ & 54.8 \\
9 & $\mathbf{8}$ & 30 & 30 & 2000 & 2.5 & 4.0 & $>99$ & 41.1 \\
10 & $\mathbf{8}$ & 120 & 30 & 2000 & 9.2 & 3.6 & $>99$ & 41.1 \\
11 & $\mathbf{1 2}$ & 60 & 30 & 2000 & 5.4 & 4.3 & $>99$ & 47.4 \\
12 & $\mathbf{1 2}$ & 60 & 30 & 0 & 0.0 & - & - & - \\
\hline
\end{tabular}

[a] $4.5 \mu \mathrm{mol}$ of catalyst, toluene $22 \mathrm{~mL}, \mathrm{~T}=25^{\circ} \mathrm{C}, 500 \mathrm{rpm}$. For all experiments the results were averaged. [b] Yield determined by mass of final reaction mixture versus mass of control reaction in toluene $(22 \mathrm{~mL})$. [c] mol of $\mathrm{C}_{2} \mathrm{H}_{4}$ converted per mol of Ni per hour [ $\operatorname{mol}\left(\mathrm{C}_{2} \mathrm{H}_{4}\right) \operatorname{mol}(\mathrm{Ni})^{-1} \mathrm{~h}^{-1}$ ]. [d] Determined by GC. [e] Determined by ${ }^{1} \mathrm{H}$ NMR spectroscopy: 1-butene was identified at $\delta=2.00,4.95$ and $5.78 \mathrm{ppm}$; resonances for the 2-butenes appear at $\delta=1.54$ and 5.37 (cis form) and at $\delta=1.58$ and 5.55 (trans) ppm.

The three nickel(II) complexes turned out to be good dimerisation catalysts, the observed TOFs ranging from $12000-43000 \mathrm{~mol}\left(\mathrm{C}_{2} \mathrm{H}_{4}\right) \mathrm{mol}(\mathrm{Ni})^{-1} \mathrm{~h}^{-1}$. For comparison, under similar conditions, the TOF observed for $\left[\mathrm{NiBr}_{2}\left(\mathrm{Ph}_{2} \mathrm{PCH}_{2} \mathrm{CH}_{2} \mathrm{PPh}_{2}\right)\right] / \mathrm{MAO}$ was 34000 $\operatorname{mol}\left(\mathrm{C}_{2} \mathrm{H}_{4}\right) \operatorname{mol}(\mathrm{Ni})^{-1} \mathrm{~h}^{-1} \cdot{ }^{[44]}$ During catalysis, ligand dissociation is very unlikely to occur, considering the observed lack of reactivity of the $\left[\mathrm{NiBr}_{2}\right] / \mathrm{MAO}$ and $\left[\mathrm{NiBr}_{2}(\mathrm{DME})\right] / \mathrm{MAO}$ systems (entries 1 and 2, Table 2). In fact, the catalytic systems were found to be active over a period longer than $2 \mathrm{~h}$, which is indicative of the high stability of the active species. The TOF reaches its maximum value after $c a .1 \mathrm{~h}$, upon which the activity decreases very slowly, possibly owing to the increasing viscosity of the solution.

The three complexes 7, 8 and 12 showed similar behaviour. With each catalyst, the observed butene selectivity was higher than $99 \%$, the longest olefins detected by gas chromatography (GC) being octenes. As usually observed for $\left[\mathrm{NiX}_{2} \mathrm{~L}_{2}\right]$ complexes, the catalyst activity of $\mathbf{8}$ increased with the amount of MAO, but the maximum activity was not yet reached using 2000 equiv. (entries 4-6, Table 2). The proportion of 1-butene obtained with 
8 depended on the reaction conditions and reached $60 \%$ in the best case $\left[\mathrm{P}\left(\mathrm{C}_{2} \mathrm{H}_{4}\right)=20\right.$ bar]. On the other hand, the amount of MAO used did not affect the product distribution.

Monitoring the reaction temperature at the beginning of catalysis revealed that upon addition of MAO and ethene, the exothermicity of the reaction was more important with 7 than with 8 and 12. This finding suggests that halide abstraction by MAO from the CD-funnel occurs more readily for chloride than for bromide, and, accordingly, that with the former complex full conversion into a catalytically active species is faster. Note that complex $\mathbf{1 2}$ is not active in the absence of MAO (entry 12, Table 2), confirming that no halide must be left in the first coordination sphere of the catalytically active species.

Dimerisation of propene. A propene dimerisation experiment was carried out with complex 8 in chlorobenzene in a $200 \mathrm{~mL}$ Büchi glass autoclave. The catalyst was generated by treatment of 8 with 2000 equiv. of MAO (Table 3). The activity of the catalyst at room temperature and under 5 bar propene, $14000 \operatorname{mol}\left(\mathrm{C}_{3} \mathrm{H}_{6}\right) \operatorname{mol}(\mathrm{Ni})^{-1} \mathrm{~h}^{-1}$, was about 8 times lower than that of $\left[\mathrm{NiBr}_{2}\left(\mathrm{Ph}_{2} \mathrm{PCH}_{2} \mathrm{CH}_{2} \mathrm{PPh}_{2}\right)\right] / \mathrm{MAO}{ }^{[45]}$ This difference is probably due to a higher crowding about the nickel centre in $\mathbf{8}$. As already observed in the ethene dimerisation experiments, the active species turned out to be remarkably stable during catalysis. The distribution (determined by $\mathrm{GC} / \mathrm{mass}$ ) of the primary products (those obtained after $\beta$ elimination) and the isomerisation products is given in Table 4.

Table 3. Catalytic propene dimerisation with 8 or $\left[\mathrm{NiBr}_{2}(\mathrm{dppe})\right]^{[\mathrm{a}]}$

\begin{tabular}{ccccccc}
\hline Entry & $\begin{array}{c}\text { Catalyst } \\
\text { precursor }\end{array}$ & {$[\mathrm{Al}] /[\mathrm{Ni}]$} & $\begin{array}{c}\text { Yield } \\
(\mathrm{g})\end{array}$ & $\begin{array}{c}\mathrm{TOF}^{[\mathrm{b}]} \\
\left(10^{4}\right)\end{array}$ & $\begin{array}{c}\text { Selectivity } \\
\mathrm{C6}^{[\mathrm{c}]}(\mathrm{wt}-\%)\end{array}$ & Ref. \\
\hline $1^{[\mathrm{d}]}$ & $\mathbf{8}$ & 2000 & 2.6 & 1.4 & 75.6 & this work \\
2 & {$\left[\mathrm{NiBr}_{2}(\mathrm{dppe})\right]$} & 400 & 21.7 & 11.5 & 87.0 & {$[45]$} \\
\hline
\end{tabular}

[a] in a $200 \mathrm{~mL}$ Büchi autoclave; $4.5 \mathrm{mmol}$ of catalyst, chlorobenzene $30 \mathrm{~mL}, \mathrm{~T}=25^{\circ} \mathrm{C}, \mathrm{t}=60 \mathrm{~min}$., $\mathrm{P}\left(\mathrm{C}_{3} \mathrm{H}_{6}\right)=5$ bar. [b] mol of $\mathrm{C}_{3} \mathrm{H}_{6}$ converted per mol of Ni per hour $\left[\mathrm{mol}\left(\mathrm{C}_{3} \mathrm{H}_{6}\right) \operatorname{mol}(\mathrm{Ni})^{-1} \mathrm{~h}^{-1}\right]$. [c] Determined by GC. [d] The results were averaged over 3 experiments. 
Table 4. Product distribution of the propene dimerisation with 8 or $\left[\mathrm{NiBr}_{2}(\mathrm{dppe})\right]$.

\begin{tabular}{cccccccccc}
\hline \multirow{2}{*}{ Entry } & \multirow{2}{*}{$\begin{array}{c}\text { Catalyst } \\
\text { precursor }\end{array}$} & \multicolumn{4}{c}{ Product distribution $(\mathrm{mol}-\%)^{[\mathrm{a}]}$} & \multicolumn{2}{c}{ MP $(\%)^{[\mathrm{b}]}$} & \multirow{2}{*}{ Ref. } \\
& 4M2P & 2M1P & 2M2P & Hex. & TMEN & & \\
\hline $1^{[\mathrm{c}]}$ & $\mathbf{8}$ & 1.4 & 32.6 & 7.8 & 52.2 & 3.6 & 2.4 & 94.0 & this Work \\
2 & {$\left[\mathrm{NiBr}_{2}(\mathrm{dppe})\right]$} & 2.2 & 35.8 & 14.8 & 41.0 & 5.0 & 1.2 & 93.8 & {$[45]$} \\
\hline
\end{tabular}

[a] Determined by GC/mass. 4M1P: 4-methyl-1-pentene, 4M2P: 4-methyl-2-pentene, 2M1P: 2methyl-1-pentene, 2M2P: 2-methyl-2-pentene, Hex.: hexenes, TMEN: 2,3-dimethyl-2-butene. [b] Total methyl-pentene (MP). [c] The results were averaged over 3 experiments.

As can be inferred from Table 4, the system clearly favours the formation of methylpentenes (MP). Interestingly, the proportion of the isomerisation product $2 \mathrm{M} 2 \mathrm{P}$ is higher than $50 \%$. This result is somewhat surprising, in view to the fact that nickel(II) catalysts containing basic diphosphines are known to form preferentially 2,3dimethylbutenes. ${ }^{[46]}$

Comments on the dimerisation mechanism: in the conventional olefin dimerisation mechanism using $\mathrm{Ni}\left(\mathrm{PR}_{3}\right)_{2} \mathrm{X}_{2} / \mathrm{MAO}$ mixtures, square planar $\left[\mathrm{Ni}\left(\mathrm{PR}_{3}\right)_{2}(\text { alkyl })(\text { olefin })\right]^{+}$ intermediates adopting a cis configuration are formed before the insertion step. ${ }^{[47,48]}$ Obviously, owing to the rather high rigidity of TRANSDIP, related intermediates with cisbonded phosphines are unattainable with this chelator. Since formation of a $\mathrm{C}-\mathrm{C}$ bond requires that the moieties undergoing coupling come close together, it appears likely that dimerisation with 7,8 or 12 involves intermediates either with a sawhorse or a trigonal bipyramidal (TBP) structure, as shown in Figure 12 (complexes $a$ and $b$ ). Note that, from a
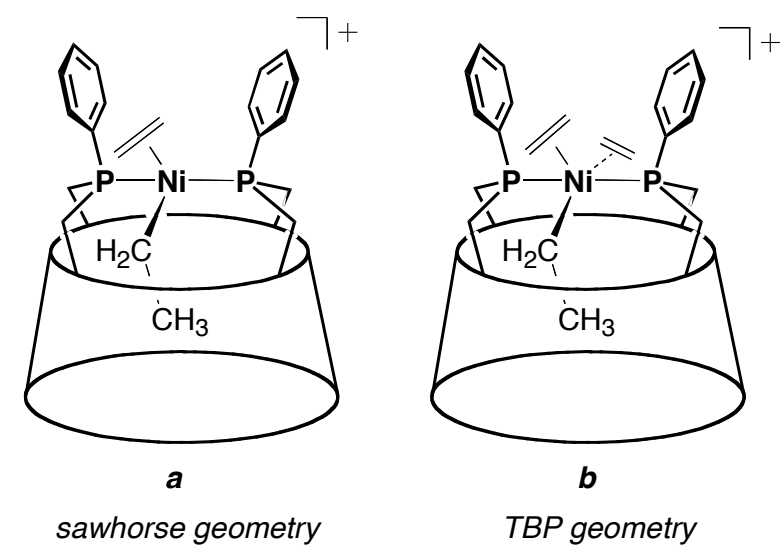

Figure 12. Proposed intermediates in the dimerisation of ethene with 7/MAO. 
stereochemical point of view, both types of complexes allow the migratory insertion to take place inside the cavity, but we have no indication that such a process occurs. It should further be mentioned here that in view of the ease of oxidising Ni(II) species, catalytic intermediates with a $\mathrm{Ni}(\mathrm{III})$ centre can formally not be ruled out. Further experiments as well as theoretical calculations are needed to exclude or confirm these hypotheses.

\section{Conclusion}

In summary, we have shown that reaction of $\mathrm{PhPLi}_{2}$ with the $6^{\mathrm{A}}, 6^{\mathrm{B}}, 6^{\mathrm{D}}, 6^{\mathrm{E}}$-tetramesylated precursor 1 occurs in a regiospecific manner, resulting in the selective formation of TRANSDIP, an A,B:D,E capped cyclodextrin with two facing phosphane units. The restricted flexibility of this $C_{2}$-symmetrical diphosphane is responsible for the existence of through-space spin-spin couplings between the phosphorus atoms and the eight-bond distant $\mathrm{CH}_{2} \mathrm{OMe}$ carbon atoms of glucose units $C$ and $F$.

TRANSDIP displays remarkable complexation properties, which are notably illustrated by its reaction with $\mathrm{d}^{8}$-metal ion halides, affording exclusively chelate complexes. The fact that no oligomers were formed in these reactions relies on both the imposed P•.•P separation and the ligand rigidified structure. Moreover, in all the square-planar complexes obtained from TRANSDIP, the phosphorus atoms are trans disposed. TRANSDIP may therefore be regarded as an authentic trans-spanning ligand. As pointed out above, such ligands are extremely rare. A further interesting feature of TRANSDIP is the presence nearby the phosphorus atoms of a receptor, which may behave as a second coordination sphere. Thus, in $\left[\mathrm{NiX}_{2}\right.$ (TRANSDIP)] complexes $(\mathrm{X}=$ halide), the cavity provides a steric protection of one of the two $\mathrm{M}-\mathrm{X}$ bonds, thereby enabling an efficient discrimination of the two halides in nucleophilic substitution reactions.

Finally, our finding that $\left[\mathrm{NiX}_{2}\right.$ (TRANSDIP)] complexes may, after activation with MAO, efficiently dimerise ethene and propene clearly indicates that the formation of intermediates in which the two phosphorus atoms are bonded in a cis fashion is not a requirement for achieving the $\mathrm{CC}$ coupling step. Elucidation of the exact mechanism leading 
to the dimers, as well as the stereochemistry of the intermediates involved in such reactions are currently underway.

\section{Experimental Section}

General procedures: All commercial reagents were used as supplied. The complexes $\left[\mathrm{PtCl}_{2}(\mathrm{PhCN})_{2}\right],{ }^{[49]}\left[\mathrm{PdCl}_{2}(\mathrm{PhCN})_{2}\right],{ }^{[49]}[\mathrm{PdClMe}(\mathrm{COD})],{ }^{[50]}$ and $[\mathrm{AuCl}(\mathrm{THT})]^{[51]}$ were synthesised according to literature procedures. All manipulations involving phosphines were performed in Schlenk-type flasks under dry nitrogen. Solvents were dried by conventional methods and distilled immediately prior to use. Column chromatography was performed on silica gel 60 (particle size 40-63 $\mu \mathrm{m}, 230-240$ mesh). $\mathrm{CDCl}_{3}$ was passed down a $5 \mathrm{~cm}$-thick alumina column and stored under nitrogen over molecular sieves $(4 \AA)$. Routine ${ }^{1} \mathrm{H},{ }^{13} \mathrm{C}\left\{{ }^{1} \mathrm{H}\right\}$ and ${ }^{31} \mathrm{P}\left\{{ }^{1} \mathrm{H}\right\}$ NMR spectra were recorded at $25^{\circ} \mathrm{C}$ with an FT Bruker and AC300 $\left({ }^{1} \mathrm{H}: 300.1\right.$ $\left.\mathrm{MHz},{ }^{13} \mathrm{C}: 75.5 \mathrm{MHz},{ }^{31} \mathrm{P}: 121.5 \mathrm{MHz}\right)$ instrument and an Avance 500 Bruker $\left({ }^{1} \mathrm{H}: 500.1\right.$ $\mathrm{MHz},{ }^{13} \mathrm{C}$ : $125.8 \mathrm{MHz}$ ) instrument. ${ }^{1} \mathrm{H}$ NMR spectral data were referenced to residual protiated solvents $\left[7.26 \mathrm{ppm}\right.$ for $\mathrm{CDCl}_{3} ; 7.16 \mathrm{ppm}$ for $\mathrm{C}_{6} \mathrm{D}_{6} ; 2.05 \mathrm{ppm}$ for $\left.\left(\mathrm{CD}_{3}\right)_{2} \mathrm{CO}\right],{ }^{13} \mathrm{C}$ chemical shifts are reported relative to deuterated solvents $\left[77.0 \mathrm{ppm}\right.$ for $\mathrm{CDCl}_{3} ; 128.06 \mathrm{ppm}$ for $\mathrm{C}_{6} \mathrm{D}_{6} ; 29.84 \mathrm{ppm}$ for $\left.\left(\mathrm{CD}_{3}\right)_{2} \mathrm{CO}\right]$, and the ${ }^{31} \mathrm{P}$ NMR data are given relative to external $\mathrm{H}_{3} \mathrm{PO}_{4}$. Mass spectra were recorded either on a Bruker MaldiTOF spectrometer using $\alpha$ cyano-4-hydroxycinnamic acid or 1,8,9-trihydroxy anthracene (dithranol) as matrix, or on a Bruker MicroTOF spectrometer (ESI) using $\mathrm{CH}_{2} \mathrm{Cl}_{2}, \mathrm{CH}_{3} \mathrm{CN}$ or $\mathrm{CH}_{3} \mathrm{OH}$ as solvent. IR spectra were recorded on a Perkin Elmer 1600 instrument. Elemental analyses were performed by the Service de Microanalyse, Institut de Chimie, Strasbourg. Melting points were determined with a Büchi 535 capillary melting-point apparatus.

Assignment of the stereochemistry of the $\mathrm{P}$ atoms (namely $R$ for both $\mathrm{P}$ atoms in TRANSDIP) was made by giving arbitrarily priority to glucose units $A$ and $D$ over glucose units $B$ and $E$, respectively. The numbering of the atoms within a glucose unit is as follows:

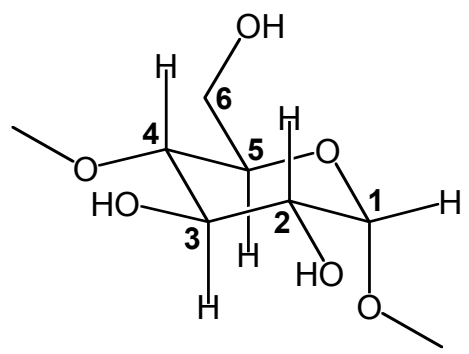




\section{Synthesis of ligands and complexes}

$6^{\mathrm{A}}, 6^{\mathrm{B}}, 6^{\mathrm{D}}, 6^{\mathrm{E}}-$ Tetradeoxy-6 ${ }^{\mathrm{A}}, 6^{\mathrm{B}}: 6^{\mathrm{D}}, 6^{\mathrm{E}}-$ bis $[(R)$-phenylphosphinidene $]-2^{\mathrm{A}}, 2^{\mathrm{B}}, 2^{\mathrm{C}}, 2^{\mathrm{D}}, 2^{\mathrm{E}}, 2^{\mathrm{F}}, 3^{\mathrm{A}}$, $3^{\mathrm{B}}, 3^{\mathrm{C}}, 3^{\mathrm{D}}, 3^{\mathrm{E}}, 3^{\mathrm{F}}, 6^{\mathrm{C}}, 6^{\mathrm{F}}$-tetradeca- $O$-methyl- $\alpha$-cyclodextrin (TRANSDIP): A solution of $\mathrm{Bu}^{n} \mathrm{Li}$ in hexane $(1.60 \mathrm{M}, 1.7 \mathrm{~mL}, 2.72 \mathrm{mmol})$ was added dropwise to a stirred solution of $\mathrm{PhPH}_{2}(0.148 \mathrm{~g}, 1.36 \mathrm{mmol}, \mathrm{ca} .0 .15 \mathrm{~mL})$ in $\mathrm{THF}(25 \mathrm{~mL})$ at $-78^{\circ} \mathrm{C}$ whereupon the yellow soultion was allowed to reach room temperature. After $10 \mathrm{~min}$, a yellow precipitate appeared. The resulting suspension was stirred at room temperature for an additional hour before being transferred within $1 \mathrm{~h}$ via a cannula to a solution of tetramesylate $1(0.400 \mathrm{~g}, 0.27 \mathrm{mmol})$ in THF $(20 \mathrm{~mL}) \mathrm{kept}$ at $20^{\circ} \mathrm{C}$. After stirring for $14 \mathrm{~h}$, the solvent was removed under vacuum and excess $\mathrm{Li}_{2} \mathrm{PPh}$ quenched with methanol $(20 \mathrm{~mL})$. After removal of the solvent in vacuo, toluene was added to the residue and the resulting suspension filtered over a bed of Celite. Evaporation to dryness afforded analytically pure TRANSDIP (yield $0.348 \mathrm{~g}, 98 \%) . R_{\mathrm{f}}\left(\mathrm{SiO}_{2}\right.$, $\left.\mathrm{CH}_{2} \mathrm{Cl}_{2} / \mathrm{MeOH}, 92: 8, \mathrm{v} / \mathrm{v}\right)=0.37 ; \mathrm{Mp} 198^{\circ} \mathrm{C}$ dec. ${ }^{1} \mathrm{H}$ NMR $\left(500.1 \mathrm{MHz}, \mathrm{CDCl}_{3}, 25^{\circ} \mathrm{C}\right): \delta$ $($ assignement by COSY $)=1.80\left(\mathrm{~m}, 4 \mathrm{H}, \mathrm{H}-6 \mathrm{a}^{\mathrm{A}, \mathrm{B}, \mathrm{D}, \mathrm{E}}\right), 3.00\left(\right.$ broad dd, $2 \mathrm{H},{ }^{2} J_{\mathrm{H}-6 \mathrm{~b}, \mathrm{H}-6 \mathrm{a}}=15.1$ $\left.\mathrm{Hz},{ }^{2} J_{\mathrm{H}-6 \mathrm{~b}, \mathrm{P}}=15.1 \mathrm{~Hz}, \mathrm{H}-6 \mathrm{~b}^{\mathrm{A}, \mathrm{D} \text { or B,E}}\right), 3.06(\mathrm{~s}, 6 \mathrm{H}, \mathrm{OMe}), 3.14\left(\mathrm{dd}, 2 \mathrm{H},{ }^{3} J_{\mathrm{H}-2, \mathrm{H}-1}=3.2 \mathrm{~Hz},{ }^{3} J_{\mathrm{H}-}\right.$ $\left.2, \mathrm{H}-3=9.9 \mathrm{~Hz}, \mathrm{H}-2^{\mathrm{B}, \mathrm{E} \text { or A,D }}\right), 3.19\left(\mathrm{dd}, 2 \mathrm{H},{ }^{3} J_{\mathrm{H}-2, \mathrm{H}-1}=3.4 \mathrm{~Hz},{ }^{3} J_{\mathrm{H}-2, \mathrm{H}-3}=9.8 \mathrm{~Hz}, \mathrm{H}-2^{\mathrm{C}, \mathrm{F}}\right), 3.20-$ $3.33\left(6 \mathrm{H}, \mathrm{H}-4^{\mathrm{A}, \mathrm{B}, \mathrm{D}, \mathrm{E}}, \mathrm{H}-6 \mathrm{~b}^{\mathrm{B}, \mathrm{E} \text { or A,D }}\right), 3.44-3.70\left(12 \mathrm{H}, \mathrm{H}-2^{\mathrm{A}, \mathrm{D} \text { or B,E }}, \mathrm{H}-3, \mathrm{H}-4^{\mathrm{C}, \mathrm{F}}, \mathrm{H}-6 \mathrm{a}^{\mathrm{C}, \mathrm{F}}\right), 3.47$ (s, $6 \mathrm{H}, \mathrm{OMe}), 3.47(\mathrm{~s}, 6 \mathrm{H}, \mathrm{OMe}), 3.52(\mathrm{~s}, 6 \mathrm{H}, \mathrm{OMe}), 3.62(\mathrm{~s}, 6 \mathrm{H}, \mathrm{OMe}), 3.65(\mathrm{~s}, 6 \mathrm{H}$, OMe), 3.68 (s, $6 \mathrm{H}, \mathrm{OMe}), 3.99-4.06\left(6 \mathrm{H}, \mathrm{H}-5^{\mathrm{A}, \mathrm{D} \text { or B,E }}, \mathrm{H}-5^{\mathrm{C}, \mathrm{F}}, \mathrm{H}-6 \mathrm{~b}^{\mathrm{C}, \mathrm{F}}\right), 4.33$ (m, $2 \mathrm{H}, \mathrm{H}-5^{\mathrm{B}, \mathrm{E}}$ or A,D $), 4.98\left(\mathrm{~d}, 2 \mathrm{H},{ }^{3} J_{\mathrm{H}-1, \mathrm{H}-2}=3.2 \mathrm{~Hz}, \mathrm{H}-1^{\mathrm{B}, \mathrm{E}}\right.$ or A,D $), 5.03\left(\mathrm{~d}, 2 \mathrm{H},{ }^{3} J_{\mathrm{H}-1, \mathrm{H}-2}=4.5 \mathrm{~Hz}, \mathrm{H}-1^{\mathrm{A}, \mathrm{D} \text { or }}\right.$ $\left.{ }^{\mathrm{B}, \mathrm{E}}\right), 5.04\left(\mathrm{~d}, 2 \mathrm{H},{ }^{3} J_{\mathrm{H}-1, \mathrm{H}-2}=3.4 \mathrm{~Hz}, \mathrm{H}-1^{\mathrm{C}, \mathrm{F}}\right), 7.18(\mathrm{~m}, 4 \mathrm{H}, m-\mathrm{H}), 7.26(\mathrm{~m}, 2 \mathrm{H}, p-\mathrm{H}), 7.47$ (m, $4 \mathrm{H}, o-\mathrm{H}) \mathrm{ppm} ;{ }^{13} \mathrm{C}\left\{{ }^{1} \mathrm{H},{ }^{31} \mathrm{P}\right\}$ NMR $\left(125.8 \mathrm{MHz}, \mathrm{CDCl}_{3}, 25^{\circ} \mathrm{C}\right): \delta$ (assigment by HMQC) $=$ $26.6\left(\mathrm{C}-6^{\mathrm{A}, \mathrm{D} \text { or B,E}}\right), 34.0\left(\mathrm{C}-6^{\mathrm{B}, \mathrm{E} \text { or A,D}}\right), 57.5,57.5,57.6\left(2-\mathrm{OCH}_{3}\right), 58.7\left(6-\mathrm{OCH}_{3}\right), 61.6,61.9$, $62.1\left(3-\mathrm{OCH}_{3}\right), 66.2\left(\mathrm{C}-5^{\mathrm{A}, \mathrm{D}}\right.$ or B,E$), 70.5\left(\mathrm{C}-5^{\mathrm{C}, \mathrm{F}}\right), 70.7\left(\mathrm{C}-6^{\mathrm{C}, \mathrm{F}}\right), 72.9\left(\mathrm{C}-5^{\mathrm{B}, \mathrm{E}}\right.$ or A,D$), 81.1(\mathrm{C}-$ $\left.3^{\mathrm{B}, \mathrm{E} \text { or } \mathrm{A}, \mathrm{D}}\right), 81.6\left(\mathrm{C}-3^{\mathrm{C}, \mathrm{F}}\right), 81.7\left(\mathrm{C}-2^{\mathrm{B}, \mathrm{E}}\right.$ or A,D $), 81.9\left(\mathrm{C}-2^{\mathrm{C}, \mathrm{F}}\right), 82.2\left(\mathrm{C}-4^{\mathrm{C}, \mathrm{F}}\right), 82.4\left(\mathrm{C}-2^{\mathrm{A}, \mathrm{D} \text { or B,E}}\right)$, $83.5\left(\mathrm{C}-3^{\mathrm{A}, \mathrm{D} \text { or B,E }}\right), 87.8\left(\mathrm{C}-4^{\mathrm{A}, \mathrm{D}}\right.$ or B,E$), 88.8\left(\mathrm{C}-4^{\mathrm{B}, \mathrm{E}}\right.$ or A,D $), 97.6\left(\mathrm{C}-1^{\mathrm{A}, \mathrm{D} \text { or B,E }}\right), 99.9\left(\mathrm{C}-1^{\mathrm{B}, \mathrm{E} \text { or }}\right.$ $\left.{ }^{\mathrm{A}, \mathrm{D}}\right), 100.3\left(\mathrm{C}-1^{\mathrm{C}, \mathrm{F}}\right), 128.3(\mathrm{~m}-\mathrm{C}), 128.5$ (p-C), 131.8 (o-C), 140.4 (ipso-C) ppm; ${ }^{31} \mathrm{P}\left\{{ }^{1} \mathrm{H}\right\}$ NMR (121.5 MHz, $\left.\mathrm{CDCl}_{3}, 25{ }^{\circ} \mathrm{C}\right): \delta=-16.8$ (s) ppm; elemental analysis (\%): calcd for $\mathrm{C}_{62} \mathrm{H}_{94} \mathrm{O}_{26} \mathrm{P}_{2} \bullet 0.5 \mathrm{CH}_{2} \mathrm{Cl}_{2}(1317.37+42.47): \mathrm{C} 55.20, \mathrm{H}$ 7.04; found: $\mathrm{C} 55.46, \mathrm{H}$ 7.01; MS (FAB): $m / z(\%): 1317.4(100)[M+\mathrm{H}]^{+}$. 
$6^{\mathrm{A}}, 6^{\mathrm{B}}, 6^{\mathrm{D}}, 6^{\mathrm{E}}-$ Tetradeoxy-6 $6^{\mathrm{A}}, 6^{\mathrm{B}}: 6^{\mathrm{D}}, 6^{\mathrm{E}}-$ bis $[(S)$-phenyloxophosphinidene $]-2^{\mathrm{A}}, 2^{\mathrm{B}}, 2^{\mathrm{C}}, 2^{\mathrm{D}}, 2^{\mathrm{E}}, 2^{\mathrm{F}}$, $\mathbf{3}^{\mathrm{A}}, 3^{\mathrm{B}}, 3^{\mathrm{C}}, 3^{\mathrm{D}}, 3^{\mathrm{E}}, 3^{\mathrm{F}}, 6^{\mathrm{C}}, 6^{\mathrm{F}}$-tetradeca- $\boldsymbol{O}$-methyl- $\alpha$-cyclodextrin (2): This di(phosphine oxide) was quantitatively formed by reacting $\mathrm{Ni}(1,5 \text {-cyclooctadiene })_{2}$ with 1 equiv. of TRANSDIP in toluene, then by bubling air through the solution. Alternatively, 2 was obtained quantitatively by bubbling air for $1 \mathrm{~h}$ through a solution of 7 (see below) in $\mathrm{CH}_{2} \mathrm{Cl}_{2}$. The product was purified by column chromatography $\left[\mathrm{SiO}_{2}, \mathrm{CH}_{2} \mathrm{Cl}_{2} / \mathrm{MeOH}, 97: 3(v / v)\right] . R_{\mathrm{f}}\left(\mathrm{SiO}_{2}\right.$, $\left.\mathrm{CH}_{2} \mathrm{Cl}_{2} / \mathrm{MeOH}, 92: 8, v / v\right)=0.35 ; \mathrm{Mp} 215^{\circ} \mathrm{C}$ dec. ${ }^{1} \mathrm{H}$ NMR $\left(300.1 \mathrm{MHz}, \mathrm{CDCl}_{3}, 25^{\circ} \mathrm{C}\right): \delta$ (assignment by COSY) $=2.10\left(\mathrm{~m}, 2 \mathrm{H}, \mathrm{H}-6 \mathrm{a}^{\mathrm{A}, \mathrm{D}}\right.$ or B,E $), 2.20\left(\mathrm{~m}, 2 \mathrm{H}, \mathrm{H}-6 \mathrm{a}^{\mathrm{B}, \mathrm{E} \text { or A,D }}\right), 2.94(\mathrm{~m}, 2$ $\mathrm{H}, \mathrm{H}-6 \mathrm{~b}^{\mathrm{B}, \mathrm{E}}$ or A,D $), 3.06\left(\mathrm{dd}, 2 \mathrm{H},{ }^{3} J_{\mathrm{H}-2, \mathrm{H}-1}=3.0 \mathrm{~Hz},{ }^{3} J_{\mathrm{H}-2, \mathrm{H}-3}=10.4 \mathrm{~Hz}, \mathrm{H}-2^{\mathrm{B}, \mathrm{E} \text { or A,D }}\right), 3.16(\mathrm{dd}, 2$ $\left.\mathrm{H},{ }^{3} J_{\mathrm{H}-2, \mathrm{H}-1}=3.3 \mathrm{~Hz},{ }^{3} J_{\mathrm{H}-2, \mathrm{H}-3}=9.7 \mathrm{~Hz}, \mathrm{H}-2^{\mathrm{C}, \mathrm{F}}\right), 3.21-3.39\left(8 \mathrm{H}, \mathrm{H}-2^{\mathrm{A}, \mathrm{D} \text { or B,E}}, \mathrm{H}-4^{\mathrm{A}, \mathrm{B}, \mathrm{D}, \mathrm{E}}, \mathrm{H}-\right.$ $\left.6 \mathrm{~b}^{\mathrm{A}, \mathrm{D} \text { or B,E }}\right), 3.33(\mathrm{~s}, 6 \mathrm{H}, \mathrm{OMe}), 3.43(\mathrm{~s}, 6 \mathrm{H}, \mathrm{OMe}), 3.46(\mathrm{~s}, 6 \mathrm{H}, \mathrm{OMe}), 3.52(\mathrm{~s}, 6 \mathrm{H}, \mathrm{OMe})$, 3.52-3.3.72 (8 H, H-3, H-4 $\left.{ }^{\mathrm{C}, \mathrm{F}}\right), 3.57$ (s, $\left.6 \mathrm{H}, \mathrm{OMe}\right), 3.66$ (s, $\left.6 \mathrm{H}, \mathrm{OMe}\right), 3.71$ (s, $\left.6 \mathrm{H}, \mathrm{OMe}\right)$, $3.84\left(\mathrm{~m}, 2 \mathrm{H}, \mathrm{H}-6 \mathrm{a}^{\mathrm{C}, \mathrm{F}}\right), 4.15$ (m, 2 H, H-6b $\left.{ }^{\mathrm{C}, \mathrm{F}}\right), 4.37$ (m, 2 H, H-5 $\left.{ }^{\mathrm{A}, \mathrm{D} \text { or B,E}}\right), 4.44$ (m, 2 H, H$\left.5^{\mathrm{C}, \mathrm{F}}\right), 4.62\left(\mathrm{~m}, 2 \mathrm{H}, \mathrm{H}-5^{\mathrm{B}, \mathrm{E}}\right.$ or A,D$), 4.93\left(\mathrm{~d}, 2 \mathrm{H},{ }^{3} J_{\mathrm{H}-1, \mathrm{H}-2}=3.3 \mathrm{~Hz}, \mathrm{H}-1^{\mathrm{C}, \mathrm{F}}\right), 4.99\left(\mathrm{~d}, 2 \mathrm{H},{ }^{3} J_{\mathrm{H}-1, \mathrm{H}-2}\right.$ $=3.0 \mathrm{~Hz}, \mathrm{H}-1^{\mathrm{B}, \mathrm{E}}$ or A,D$), 5.05\left(\mathrm{~d}, 2 \mathrm{H},{ }^{3} J_{\mathrm{H}-1, \mathrm{H}-2}=4.3 \mathrm{~Hz}, \mathrm{H}-1^{\mathrm{A}, \mathrm{D} \text { or B,E }}\right), 7.45-7.55(6 \mathrm{H}, m-\mathrm{H}, p-$ $\mathrm{H}), 7.71(\mathrm{~m}, 4 \mathrm{H}, o-\mathrm{H}) \mathrm{ppm} ;{ }^{13} \mathrm{C}\left\{{ }^{1} \mathrm{H}\right\} \mathrm{NMR}\left(75.5 \mathrm{MHz}, \mathrm{CDCl}_{3}, 25^{\circ} \mathrm{C}\right): \delta$ (assignment by $\mathrm{HMQC})=34.0\left(\mathrm{~d},{ }^{1} J_{\mathrm{C}, \mathrm{P}}=67.0 \mathrm{~Hz}, \mathrm{C}-6^{\mathrm{A}, \mathrm{D} \text { or B,E}}\right), 40.7\left(\mathrm{~d},{ }^{1} J_{\mathrm{C}, \mathrm{P}}=67.6 \mathrm{~Hz}, \mathrm{C}-6^{\mathrm{A}, \mathrm{D} \text { or B,E}}\right), 57.4$, 57.6, $57.6\left(2-\mathrm{OCH}_{3}\right), 58.7\left(6-\mathrm{OCH}_{3}\right), 61.7[\times 2], 62.4\left(3-\mathrm{OCH}_{3}\right), 63.4\left(\mathrm{~d},{ }^{2} J_{\mathrm{C}, \mathrm{P}}=5.6 \mathrm{~Hz}, \mathrm{C}-5^{\mathrm{A}, \mathrm{D}}\right.$ or B,E $), 66.8\left(\mathrm{C}-5^{\mathrm{B}, \mathrm{E} \text { or A,D}}\right), 71.0[\times 2]\left(\mathrm{C}-5^{\mathrm{C}, \mathrm{F}}, \mathrm{C}-6^{\mathrm{C}, \mathrm{F}}\right), 79.9,81.3,81.8,82.1,82.3,82.5,82.6(\mathrm{C}-$ 2, C-3, C-4 $\left.{ }^{\mathrm{C}, \mathrm{F}}\right), 87.3\left(\mathrm{~d},{ }^{3} J_{\mathrm{C}, \mathrm{P}}=11.8 \mathrm{~Hz}, \mathrm{C}-4^{\mathrm{A}, \mathrm{D}}\right.$ or B,E$), 90.1\left(\mathrm{~d},{ }^{3} J_{\mathrm{C}, \mathrm{P}}=5.0 \mathrm{~Hz}, \mathrm{C}-4^{\mathrm{B}, \mathrm{E}}\right.$ or A,D $)$, $97.6\left(\mathrm{C}-1^{\mathrm{A}, \mathrm{D} \text { or B,E}}\right), 100.2\left(\mathrm{C}-1^{\mathrm{C}, \mathrm{F}}\right), 100.7\left(\mathrm{C}-1^{\mathrm{B}, \mathrm{E} \text { or A,D}}\right), 129.0\left(\mathrm{~d},{ }^{2} J_{\mathrm{C}, \mathrm{P}}=11.8 \mathrm{~Hz}, o-\mathrm{C}\right), 129.4$ $\left(\mathrm{d},{ }^{3} J_{\mathrm{C}, \mathrm{P}}=9.3 \mathrm{~Hz}, m-\mathrm{C}\right), 131.9\left(\mathrm{~d},{ }^{4} J_{\mathrm{C}, \mathrm{P}}=2.5 \mathrm{~Hz}, p-\mathrm{C}\right), 133.9$ (d, $J_{\mathrm{C}, \mathrm{P}}=98.0 \mathrm{~Hz}$, ipso-C) ppm; ${ }^{31} \mathrm{P}\left\{{ }^{1} \mathrm{H}\right\} \mathrm{NMR}\left(121.5 \mathrm{MHz}, \mathrm{CDCl}_{3}, 25^{\circ} \mathrm{C}\right): \delta=40.2$ (s) ppm; elemental analysis (\%): calcd for $\mathrm{C}_{62} \mathrm{H}_{94} \mathrm{O}_{28} \mathrm{P}_{2}$ (1349.34): C 55.19, $\mathrm{H}$ 7.02; found: C 55.08, H 6.99; MS (ESI-TOF): $\mathrm{m} / \mathrm{z}$ (\%): $1371.5(100)[M+\mathrm{Na}]^{+}$.

$6^{\mathrm{A}}, 6^{\mathrm{B}}, 6^{\mathrm{D}}, 6^{\mathrm{E}}$-Tetradeoxy-6 ${ }^{\mathrm{A}}, 6^{\mathrm{B}}: 6^{\mathrm{D}}, 6^{\mathrm{E}}-$ bis $[(S)$-phenylsulfidophosphinidene $]-2^{\mathrm{A}}, 2^{\mathrm{B}}, 2^{\mathrm{C}}, 2^{\mathrm{D}}$, $2^{\mathrm{E}}, 2^{\mathrm{F}}, 3^{\mathrm{A}}, 3^{\mathrm{B}}, 3^{\mathrm{C}}, 3^{\mathrm{D}}, 3^{\mathrm{E}}, 3^{\mathrm{F}}, 6^{\mathrm{C}}, 6^{\mathrm{F}}$-tetradeca- $O$-methyl- $\alpha$-cyclodextrin (3): Solid sulfur (0.005 g, $0.15 \mathrm{mmol})$ was added at room temperature to a solution of TRANSDIP $(0.100 \mathrm{~g}, 0.08$ mmol) in THF $(10 \mathrm{~mL})$ under vigorous stirring. After $3 \mathrm{~h}$ the reaction mixture was concentrated to $5 \mathrm{~mL}$ and pentane $(100 \mathrm{~mL})$ was added. The suspension was then filtered over Celite. Evaporation of pentane afforded analytically pure $\mathbf{3}$ as a pale yellow powder (yield: $0.103 \mathrm{~g}, 98 \%) . R_{\mathrm{f}}\left(\mathrm{SiO}_{2}, \mathrm{CH}_{2} \mathrm{Cl}_{2} / \mathrm{MeOH}, 92: 8, \mathrm{v} / \mathrm{v}\right)=0.34 ; \mathrm{Mp} 184^{\circ} \mathrm{C}$ dec. ${ }^{1} \mathrm{H}$ NMR $(300.1$ $\left.\mathrm{MHz}, \mathrm{CDCl}_{3}, 25^{\circ} \mathrm{C}\right): \delta$ (assignment by COSY $)=2.05\left(\mathrm{~m}, 2 \mathrm{H}, \mathrm{H}-6 \mathrm{a}^{\mathrm{A}, \mathrm{D} \text { or B,E}}\right), 2.45(\mathrm{~m}, 2 \mathrm{H}$, 
H-6a ${ }^{\mathrm{B}, \mathrm{E}}$ or A,D $), 3.02-3.33\left(14 \mathrm{H}, \mathrm{H}-2, \mathrm{H}-4^{\mathrm{A}, \mathrm{B}, \mathrm{D}, \mathrm{E}}, \mathrm{H}-6 \mathrm{~b}^{\mathrm{A}, \mathrm{B}, \mathrm{D}, \mathrm{E}}\right), 3.26$ (s, $\left.6 \mathrm{H}, \mathrm{OMe}\right), 3.45$ (s, 12 H, OMe), 3.47-3.71 (8 H, H-3, H-4 ${ }^{\mathrm{C}, \mathrm{F}}$ ), 3.54 (s, $\left.6 \mathrm{H}, \mathrm{OMe}\right), 3.59$ (s, $\left.6 \mathrm{H}, \mathrm{OMe}\right), 3.66$ (s, $6 \mathrm{H}$, OMe), 3.74 (s, $6 \mathrm{H}, \mathrm{OMe}), 3.96$ (m, $\left.2 \mathrm{H}, \mathrm{H}-6 \mathrm{a}^{\mathrm{C}, \mathrm{F}}\right), 4.22$ (m, $\left.2 \mathrm{H}, \mathrm{H}-5^{\mathrm{C}, \mathrm{F}}\right), 4,32-4.44(4 \mathrm{H}, \mathrm{H}-$ $\left.5^{\mathrm{B}, \mathrm{E} \text { or A,D }}, \mathrm{H}-6 \mathrm{~b}^{\mathrm{C}, \mathrm{F}}\right), 4.77\left(\mathrm{~m}, 2 \mathrm{H}, \mathrm{H}-5^{\mathrm{A}, \mathrm{B}}\right.$ or D,E$), 4.92\left(\mathrm{~d}, 2 \mathrm{H},{ }^{3} J_{\mathrm{H}-1, \mathrm{H}-2}=2.8 \mathrm{~Hz}, \mathrm{H}-1^{\mathrm{C}, \mathrm{F}}\right), 4.95$ $\left(\mathrm{d}, 2 \mathrm{H},{ }^{3} J_{\mathrm{H}-1, \mathrm{H}-2}=2.5 \mathrm{~Hz}, \mathrm{H}-1^{\mathrm{A}, \mathrm{D} \text { or B,E}}\right), 5.08\left(\mathrm{~d}, 2 \mathrm{H},{ }^{3} J_{\mathrm{H}-1, \mathrm{H}-2}=4.0 \mathrm{~Hz}, \mathrm{H}-1^{\mathrm{B}, \mathrm{E} \text { or A,D}}\right), 7.48(\mathrm{~m}$, $4 \mathrm{H}, m-\mathrm{H}), 7.54(\mathrm{~m}, 2 \mathrm{H}, p-\mathrm{H}), 7.96(\mathrm{~m}, 4 \mathrm{H}, o-\mathrm{H}) \mathrm{ppm} ;{ }^{13} \mathrm{C}\left\{{ }^{1} \mathrm{H}\right\} \mathrm{NMR}\left(75.5 \mathrm{MHz}, \mathrm{CDCl}_{3}\right.$, $\left.25^{\circ} \mathrm{C}\right): \delta$ (assigment by HMQC) $=38.9\left(\mathrm{~d},{ }^{1} J_{\mathrm{C}-6, \mathrm{P}}=52.6 \mathrm{~Hz}, \mathrm{C}-6^{\mathrm{B}, \mathrm{E}}\right.$ or A,D $), 43.3\left(\mathrm{~d},{ }^{1} J_{\mathrm{C}-6, \mathrm{P}}=\right.$ $\left.50.8 \mathrm{~Hz}, \mathrm{C}-6^{\mathrm{A}, \mathrm{D} \text { or B,E}}\right), 57.4,57.5,57.7\left(2-\mathrm{OCH}_{3}\right), 58.7\left(6-\mathrm{OCH}_{3}\right), 61.6,61.9,62.5\left(3-\mathrm{OCH}_{3}\right)$, $63.9\left(\mathrm{~m}, \mathrm{C}-5^{\mathrm{B}, \mathrm{E} \text { or A,D}}\right), 68.5\left(\mathrm{C}-5^{\mathrm{A}, \mathrm{D} \text { or B,E }}\right), 71.5\left(\mathrm{C}-5^{\mathrm{C}, \mathrm{F}}\right), 72.0\left(\mathrm{C}-6^{\mathrm{C}, \mathrm{F}}\right), 80.3,81.3,81.8,82.0$, $82.2,82.2,83.0\left(\mathrm{C}-2, \mathrm{C}-3, \mathrm{C}-4^{\mathrm{C}, \mathrm{F}}\right), 87.0\left(\mathrm{~m}, \mathrm{C}-4^{\mathrm{B}, \mathrm{E} \text { or A,D}}\right), 89.8\left(\mathrm{~m}, \mathrm{C}-4^{\mathrm{A}, \mathrm{D} \text { or B,E}}\right), 97.7\left(\mathrm{C}-1^{\mathrm{B}, \mathrm{E} \text { or }}\right.$ A,D $), 100.3\left(\mathrm{C}-1^{\mathrm{A}, \mathrm{D} \text { or B,E}}\right), 100.6\left(\mathrm{C}-1^{\mathrm{C}, \mathrm{F}}\right), 128.4(\mathrm{~m}, m-\mathrm{C}), 130.5(\mathrm{~m}, o-\mathrm{C}), 131.1(p-\mathrm{C}), 135.1$ $\left(\mathrm{d}, J_{\mathrm{C}, \mathrm{P}}=78.8 \mathrm{~Hz}\right.$, ipso-C) ppm; ${ }^{31} \mathrm{P}\left\{{ }^{1} \mathrm{H}\right\} \mathrm{NMR}\left(121.5 \mathrm{MHz}, \mathrm{CDCl}_{3}, 25^{\circ} \mathrm{C}\right): \delta=40.8$ (s) ppm; elemental analysis (\%): calcd for $\mathrm{C}_{62} \mathrm{H}_{94} \mathrm{O}_{26} \mathrm{P}_{2} \mathrm{~S}_{2} \cdot 2\left(\mathrm{CH}_{2} \mathrm{Cl}_{2}\right)(1381.47+169.87): \mathrm{C} 49.55, \mathrm{H}$ 6.37; found: C 49.32, H 6.48; MS (ESI-TOF): $m / z(\%)$ : $1403.6(100)[M+\mathrm{H}]^{+}$. When the sulfuration reaction was carried out with one equivalent of sulfur, a mixture of starting material, monosulfide 4 and disulfide 3 (major compound) was obtained. Further treatment of the solution with additional sulfur led quantitatively to 3 . The phosphane sulfides $\mathbf{3}$ and $\mathbf{4}$ could not be separated. ${ }^{31} \mathrm{P}\left\{{ }^{1} \mathrm{H}\right\}$ NMR: $\left(121.5 \mathrm{MHz}, \mathrm{CDCl}_{3}, 25^{\circ} \mathrm{C}\right): \delta=42.2\left(\mathrm{~d}, \mathrm{P}(\mathrm{V}), J\left(\mathrm{PP}^{\prime}\right)\right.$ $=48.7 \mathrm{~Hz}),-19.5\left(\mathrm{~d}, \mathrm{P}(\mathrm{III}), J\left(\mathrm{PP}^{\prime}\right)=48.7 \mathrm{~Hz}\right) \mathrm{ppm}$.

Trans-P,P'-dichloro- $\left\{6^{\mathrm{A}}, 6^{\mathrm{B}}, 6^{\mathrm{D}}, 6^{\mathrm{E}}\right.$-tetradeoxy- $6^{\mathrm{A}}, 6^{\mathrm{B}}: 6^{\mathrm{D}}, 6^{\mathrm{E}}$-bis $[(R)$-phenylphosphinidene $]-$ $2^{\mathrm{A}}, 2^{\mathrm{B}}, 2^{\mathrm{C}}, 2^{\mathrm{D}}, 2^{\mathrm{E}}, 2^{\mathrm{F}}, 3^{\mathrm{A}}, 3^{\mathrm{B}}, 3^{\mathrm{C}}, 3^{\mathrm{D}}, 3^{\mathrm{E}}, 3^{\mathrm{F}}, 6^{\mathrm{C}}, 6^{\mathrm{F}}$-tetradeca- $O$-methyl- $\alpha$-cyclodextrin $\}$ platinum(II) (5): A solution of $\left[\mathrm{PtCl}_{2}(\mathrm{PhCN})_{2}\right](0.047 \mathrm{~g}, 0.10 \mathrm{mmol})$ and TRANSDIP $(0.130 \mathrm{~g}, 0.10$ mmol) in toluene $(25 \mathrm{~mL})$ was refluxed for $3 \mathrm{~d}$. The solution was concentrated to $c a .5 \mathrm{~mL}$ and pentane $(140 \mathrm{~mL})$ was added to precipitate small amounts of unreacted starting complex. The solution was filtered over Celite. Evaporation of pentane afforded analytically pure $\mathbf{5}$ as a pale yellow powder (yield $0.153 \mathrm{~g}, 98 \%) . R_{\mathrm{f}}\left(\mathrm{SiO}_{2}, \mathrm{CH}_{2} \mathrm{Cl}_{2} / \mathrm{MeOH}, 90: 10\right.$, v/v) $=0.46$; $\mathrm{Mp}$ $>250^{\circ} \mathrm{C} .{ }^{1} \mathrm{H}$ NMR $\left(300.1 \mathrm{MHz}, \mathrm{CDCl}_{3}, 25{ }^{\circ} \mathrm{C}\right): \delta$ (assignment by COSY $)=2.28(\mathrm{~m}, 2 \mathrm{H}, \mathrm{H}-$ $\left.6 \mathrm{a}^{\mathrm{A}, \mathrm{D} \text { or B,E}}\right), 2.63\left(\mathrm{ddd}, 2 \mathrm{H},{ }^{2} J_{\mathrm{H}-6 \mathrm{a}, \mathrm{H}-6 \mathrm{~b}}=5.5 \mathrm{~Hz},{ }^{3} J_{\mathrm{H}-6 \mathrm{a}, \mathrm{H}-5}=5.5 \mathrm{~Hz},{ }^{3} J_{\mathrm{H}-6 \mathrm{a}, \mathrm{P}}=14.6 \mathrm{~Hz}, \mathrm{H}-6 \mathrm{a}^{\mathrm{B}, \mathrm{E} \text { or }}\right.$ $\left.{ }^{\mathrm{A}, \mathrm{D}}\right), 3.07-3.22\left(10 \mathrm{H}, \mathrm{H}-2, \mathrm{H}-4^{\mathrm{A}, \mathrm{B}, \mathrm{D}, \mathrm{E}}\right), 3.31-3.39\left(4 \mathrm{H}, \mathrm{H}-6 \mathrm{~b}^{\mathrm{A}, \mathrm{B}, \mathrm{D}, \mathrm{E}}\right), 3.43\left(\mathrm{~m}, 2 \mathrm{H}, \mathrm{H}-3^{\mathrm{A}, \mathrm{D}}\right.$ or $\left.{ }^{\mathrm{B}, \mathrm{E}}\right), 3.44(\mathrm{~s}, 6 \mathrm{H}, \mathrm{OMe}), 3.47(\mathrm{~s}, 6 \mathrm{H}, \mathrm{OMe}), 3.52(\mathrm{~s}, 12 \mathrm{H}, \mathrm{OMe}), 3.52-3.65\left(4 \mathrm{H}, \mathrm{H}-3^{\mathrm{B}, \mathrm{E}}\right.$ or A,D,$\left.H-3^{\mathrm{C}, \mathrm{F}}\right), 3.64$ (s, $\left.6 \mathrm{H}, \mathrm{OMe}\right), 3.65$ (s, $\left.6 \mathrm{H}, \mathrm{OMe}\right), 3.74(\mathrm{~s}, 6 \mathrm{H}, \mathrm{OMe}), 3.81(\mathrm{~m}, 2 \mathrm{H}, \mathrm{H}-$ $\left.6 \mathrm{a}^{\mathrm{C}, \mathrm{F}}\right), 3.86\left(\mathrm{~m}, 2 \mathrm{H}, \mathrm{H}-4^{\mathrm{C}, \mathrm{F}}\right), 4.51-4.64\left(6 \mathrm{H}, \mathrm{H}-5^{\mathrm{A}, \mathrm{D} \text { or B,E }}, \mathrm{H}-5^{\mathrm{C}, \mathrm{F}}, \mathrm{H}-6 \mathrm{~b}^{\mathrm{C}, \mathrm{F}}\right), 4.93\left(\mathrm{~d}, 2 \mathrm{H},{ }^{3} J_{\mathrm{H}-}\right.$ 
1,H-2 $=4.2 \mathrm{~Hz}, \mathrm{H}-1^{\mathrm{A}, \mathrm{D} \text { or B,E}}$ ), 5.05 (two overlapping d, $4 \mathrm{H}, \mathrm{H}-1^{\mathrm{B}, \mathrm{E}}$ or A,D, $\left.\mathrm{H}-1^{\mathrm{C}, \mathrm{F}}\right), 5.23(\mathrm{~m}, 2 \mathrm{H}$, $\mathrm{H}-5^{\mathrm{B}, \mathrm{E}}$ or A,D $), 7.28-7.37(6 \mathrm{H}, m-\mathrm{H}, p-\mathrm{H}), 7.49(\mathrm{~m}, 4 \mathrm{H}, o-\mathrm{H}) \mathrm{ppm} ;{ }^{13} \mathrm{C}\left\{{ }^{1} \mathrm{H}\right\} \mathrm{NMR}(75.5 \mathrm{MHz}$, $\left.\mathrm{CDCl}_{3}, 25^{\circ} \mathrm{C}\right): \delta$ (assignment by HMQC) $=30.2\left(\mathrm{~m}, \mathrm{C}-6^{\mathrm{A}, \mathrm{D}}\right.$ or B,E $), 35.8$ (virtual t, $\left.\right|^{1} J_{\mathrm{C}, \mathrm{P}}+$ $\left.{ }^{3} J_{\mathrm{C}, \mathrm{P}^{\prime}} \mid=26.6 \mathrm{~Hz}, \mathrm{C}-6^{\mathrm{B}, \mathrm{E} \text { or A,D}}\right), 57.5,58.0,58.7\left(2-\mathrm{OCH}_{3}\right), 59.3\left(6-\mathrm{OCH}_{3}\right), 61.7,61.7,62.0$ (3$\left.\mathrm{OCH}_{3}\right), 66.1\left(\mathrm{C}-5^{\mathrm{A}, \mathrm{D} \text { or B,E }}\right), 67.9\left(\mathrm{C}-5^{\mathrm{B}, \mathrm{E} \text { or A,D }}\right), 70.6\left(\mathrm{C}-5^{\mathrm{C}, \mathrm{F}}\right), 71.8\left(\mathrm{C}-6^{\mathrm{C}, \mathrm{F}}\right), 80.6\left(\mathrm{C}-4^{\mathrm{C}, \mathrm{F}}\right), 81.1$ $\left(\mathrm{C}-3^{\mathrm{C}, \mathrm{F}}\right), 81.3\left(\mathrm{C}-3^{\mathrm{B}, \mathrm{E} \text { or A,D}}\right), 81.4[\times 2]\left(\mathrm{C}-2^{\mathrm{A}, \mathrm{B}, \mathrm{D}, \mathrm{E}}\right), 83.0\left(\mathrm{C}-3^{\mathrm{A}, \mathrm{D} \text { or B,E }}\right), 83.2\left(\mathrm{C}-2^{\mathrm{C}, \mathrm{F}}\right), 86.5$ (virtual t, $\left.\left.\right|^{3} J_{\mathrm{C}, \mathrm{P}}+{ }^{5} J_{\mathrm{C}, \mathrm{P}} \mid=9.5 \mathrm{~Hz}, \mathrm{C}-4^{\mathrm{A}, \mathrm{D} \text { or B,E}}\right), 89.9\left(\mathrm{C}-4^{\mathrm{B}, \mathrm{E} \text { or A,D}}\right), 97.3\left(\mathrm{C}-1^{\mathrm{B}, \mathrm{E}}\right.$ or A,D $), 97.5(\mathrm{C}-$ $\left.1^{\mathrm{A}, \mathrm{D} \text { or B,E }}\right), 100.9\left(\mathrm{C}-1^{\mathrm{C}, \mathrm{F}}\right), 127.8$ (virtual t, $\left.\left.\right|^{3} J_{\mathrm{C}, \mathrm{P}}+{ }^{5} J_{\mathrm{C}, \mathrm{P}}{ }^{\prime}=10.0 \mathrm{~Hz}, m-\mathrm{C}\right), 129.6(p-\mathrm{C}), 131.3$ (virtual t, $\left.\right|^{2} J_{\mathrm{C}, \mathrm{P}}+{ }^{4} J_{\mathrm{C}, \mathrm{P}} \mid=9.5 \mathrm{~Hz}, o-\mathrm{C}$ ), 133.4 (virtual t, $\left|{ }^{1} J_{\mathrm{C}, \mathrm{P}}+{ }^{3} J_{\mathrm{C}, \mathrm{P}}\right|=57.8 \mathrm{~Hz}$, ipso-C) ppm; ${ }^{31} \mathrm{P}\left\{{ }^{1} \mathrm{H}\right\}$ NMR $\left(121.5 \mathrm{MHz}, \mathrm{CDCl}_{3}, 25{ }^{\circ} \mathrm{C}\right): \delta=-6.5$ (s with Pt satellites, ${ }^{1} J_{\mathrm{P}, \mathrm{Pt}}=2463 \mathrm{~Hz}$ ) ppm; elemental analysis (\%): calcd for $\mathrm{C}_{62} \mathrm{H}_{94} \mathrm{O}_{26} \mathrm{P}_{2} \mathrm{PtCl}_{2}$ (1583.37): C 47.03, $\mathrm{H}$ 5.98; found: C 47.14, H 6.05; MS (FAB): $m / z(\%): 1547.2(100)[M-\mathrm{Cl}]^{+}$.

Trans-P,P'-dichloro- $\left\{6^{\mathrm{A}}, 6^{\mathrm{B}}, 6^{\mathrm{D}}, 6^{\mathrm{E}}\right.$-tetradeoxy-6 $6^{\mathrm{A}}, 6^{\mathrm{B}}: 6^{\mathrm{D}}, 6^{\mathrm{E}}$-bis $[(R)$-phenylphosphinidene $]-$ $2^{\mathrm{A}}, 2^{\mathrm{B}}, 2^{\mathrm{C}}, 2^{\mathrm{D}}, 2^{\mathrm{E}}, 2^{\mathrm{F}}, 3^{\mathrm{A}}, 3^{\mathrm{B}}, 3^{\mathrm{C}}, 3^{\mathrm{D}}, 3^{\mathrm{E}}, 3^{\mathrm{F}}, 6^{\mathrm{C}}, 6^{\mathrm{F}}$-tetradeca- $O$-methyl- $\alpha$-cyclodextrin $\}$

palladium(II) (6): A solution of $\left[\mathrm{PdCl}_{2}(\mathrm{PhCN})_{2}\right](0.047 \mathrm{~g}, 0.12 \mathrm{mmol})$ in $\mathrm{CH}_{2} \mathrm{Cl}_{2}(5 \mathrm{~mL})$ was added at room temperature to a solution of TRANSDIP $(0.160 \mathrm{~g}, 0.12 \mathrm{mmol})$ in $\mathrm{CH}_{2} \mathrm{Cl}_{2}(10$ $\mathrm{mL}$ ) under vigorous stirring. After $0.5 \mathrm{~h}$ the reaction mixture was concentrated to $5 \mathrm{~mL}$ and pentane $(100 \mathrm{~mL})$ was added. The suspension was then filtered over Celite. Evaporation of pentane afforded analytically pure 6 as a pale yellow powder. Washings of the Celite layer with hot heptane afforded further amounts of 6 (yield: $0.174 \mathrm{~g}, 97 \%) . R_{\mathrm{f}}\left(\mathrm{SiO}_{2}\right.$, $\left.\mathrm{CH}_{2} \mathrm{Cl}_{2} / \mathrm{MeOH}, 90: 10, \mathrm{v} / \mathrm{v}\right)=0.45 ; \mathrm{Mp} 219-223{ }^{\circ} \mathrm{C} .{ }^{1} \mathrm{H}$ NMR $\left(300.1 \mathrm{MHz}, \mathrm{CDCl}_{3}, 25{ }^{\circ} \mathrm{C}\right): \delta=$ $2.13\left(\mathrm{~m}, 2 \mathrm{H}, \mathrm{H}-6 \mathrm{a}^{\mathrm{A}, \mathrm{D}}\right.$ or B,E $), 2.63\left(\mathrm{ddd}, 2 \mathrm{H},{ }^{2} J_{\mathrm{H}-6 \mathrm{a}, \mathrm{H}-6 \mathrm{~b}}=4.7 \mathrm{~Hz},{ }^{3} J(\mathrm{H}-6 \mathrm{a}, \mathrm{H}-5)=4.7 \mathrm{~Hz},{ }^{3} J_{\mathrm{H}-6 \mathrm{a}, \mathrm{P}}\right.$ $=14.7 \mathrm{~Hz}, \mathrm{H}-6 \mathrm{a}^{\mathrm{B}, \mathrm{E}}$ or A,D $), 3.08-3.22\left(10 \mathrm{H}, \mathrm{H}-2, \mathrm{H}-4^{\mathrm{A}, \mathrm{B}, \mathrm{D}, \mathrm{E}}\right), 3.33-3.37\left(4 \mathrm{H}, \mathrm{H}-6 \mathrm{~b}^{\mathrm{A}, \mathrm{B}, \mathrm{D}, \mathrm{E}}\right), 3.41$ (m, 2 H, H-3 $\left.{ }^{\mathrm{A}, \mathrm{D} \text { or B,E}}\right), 3.45$ (s, $\left.6 \mathrm{H}, \mathrm{OMe}\right), 3.47$ (s, $\left.6 \mathrm{H}, \mathrm{OMe}\right), 3.52$ (s, $\left.12 \mathrm{H}, \mathrm{OMe}\right), 3.54-3.68$ $\left(4 \mathrm{H}, \mathrm{H}-3^{\mathrm{B}, \mathrm{E} \text { or A,D }}, \mathrm{H}^{\mathrm{C}}{ }^{\mathrm{C}, \mathrm{F}}\right), 3.64$ (s, $\left.6 \mathrm{H}, \mathrm{OMe}\right), 3.65$ (s, $\left.6 \mathrm{H}, \mathrm{OMe}\right), 3.73$ (s, $\left.6 \mathrm{H}, \mathrm{OMe}\right), 3.79$ $3.88\left(4 \mathrm{H}, \mathrm{H}-4^{\mathrm{C}, \mathrm{F}}, \mathrm{H}-6 \mathrm{a}^{\mathrm{C}, \mathrm{F}}\right), 4.48-4.62\left(6 \mathrm{H}, \mathrm{H}-5^{\mathrm{A}, \mathrm{D} \text { or B,E }}, \mathrm{H}-5^{\mathrm{C}, \mathrm{F}}, \mathrm{H}-6 \mathrm{~b}^{\mathrm{C}, \mathrm{F}}\right), 4.93\left(\mathrm{~d}, 2 \mathrm{H},{ }^{3} J_{\mathrm{H}-1, \mathrm{H}-}\right.$ $\left.{ }_{2}=4.2 \mathrm{~Hz}, \mathrm{H}-1^{\mathrm{A}, \mathrm{D} \text { or B,E}}\right), 5.05\left(\mathrm{~d}, 4 \mathrm{H},{ }^{3} J_{\mathrm{H}-1, \mathrm{H}-2}=3.4 \mathrm{~Hz}, \mathrm{H}-1^{\mathrm{B}, \mathrm{E} \text { or A,D }}, \mathrm{H}-1^{\mathrm{C}, \mathrm{F}}\right), 5.23(\mathrm{~m}, 2 \mathrm{H}, \mathrm{H}-$ $\left.5^{\mathrm{B}, \mathrm{E} \text { or A,D }}\right), 7.30-7.36(6 \mathrm{H}, m-\mathrm{H}, p-\mathrm{H}), 7.51(\mathrm{~m}, 4 \mathrm{H}, o-\mathrm{H}) \mathrm{ppm} ;{ }^{13} \mathrm{C}\left\{{ }^{1} \mathrm{H}\right\} \mathrm{NMR}(75.5 \mathrm{MHz}$, $\mathrm{CDCl}_{3}, 25{ }^{\circ} \mathrm{C}$ ): $\delta=30.2$ (virtual t, $\left.\left|{ }^{1} J_{\mathrm{C}, \mathrm{P}}+{ }^{3} J_{\mathrm{C}, \mathrm{P}}\right|=25.0 \mathrm{~Hz}, \mathrm{C}-6^{\mathrm{A}, \mathrm{D} \text { or B,E}}\right), 36.2$ (virtual t, $\mid{ }^{1} J_{\mathrm{C}, \mathrm{P}}$ $\left.+{ }^{3} J_{\mathrm{C}, \mathrm{P}}{ }^{\prime} \mid=20.0 \mathrm{~Hz}, \mathrm{C}-6^{\mathrm{B}, \mathrm{E} \text { or A,D }}\right), 57.5,58.0,58.6\left(2-\mathrm{OCH}_{3}\right), 59.4\left(6-\mathrm{OCH}_{3}\right), 61.7,61.7,62.0$ $\left(3-\mathrm{OCH}_{3}\right), 66.0$ (br signal with triplet shape, C-5 $\left.{ }^{\mathrm{A}, \mathrm{D} \text { or B,E}}\right), 68.3$ (br signal with triplet shape,C$\left.5^{\mathrm{B}, \mathrm{E} \text { or A,D }}\right), 70.8\left(\mathrm{C}-5^{\mathrm{C}, \mathrm{F}}\right), 72.0\left(\mathrm{C}-6^{\mathrm{C}, \mathrm{F}}\right), 80.9,81.0,81.1,81.3,81.4,82.9,83.1(\mathrm{C}-2, \mathrm{C}-3, \mathrm{C}-$ $4^{\mathrm{C}, \mathrm{F}}$ ), 86.6 (virtual t, $\left.\right|^{3} J_{\mathrm{C}, \mathrm{P}}+{ }^{5} J_{\mathrm{C}, \mathrm{P}} \mid=9.5 \mathrm{~Hz}, \mathrm{C}-4^{\mathrm{A}, \mathrm{D} \text { or B,E}}$ ), 89.9 (br signal with triplet shape, C- 
$\left.4^{\mathrm{B}, \mathrm{E} \text { or A,D }}\right), 97.5[\times 2]\left(\mathrm{C}-1^{\mathrm{A}, \mathrm{B}, \mathrm{D}, \mathrm{E}}\right), 101.0\left(\mathrm{C}-1^{\mathrm{C}, \mathrm{F}}\right), 127.9\left(\right.$ virtual t, $\left.\left.\right|^{3} J_{\mathrm{C}, \mathrm{P}}+{ }^{5} J_{\mathrm{C}, \mathrm{P}}{ }^{\prime} \mid=9.5 \mathrm{~Hz}, m-\mathrm{C}\right)$, 129.6 (p-C), 131.3 (virtual t, $\left.\right|^{2} J_{\mathrm{C}, \mathrm{P}}+{ }^{4} J_{\mathrm{C}, \mathrm{P}} \mid=9.5 \mathrm{~Hz}, o-\mathrm{C}$ ), 134.5 (virtual t, $\left|{ }^{1} J_{\mathrm{C}, \mathrm{P}}+{ }^{3} J_{\mathrm{C}, \mathrm{P}}{ }^{\prime}\right|=$ $50.0 \mathrm{~Hz}$, ipso-C) ppm; ${ }^{31} \mathrm{P}\left\{{ }^{1} \mathrm{H}\right\} \mathrm{NMR}\left(121.5 \mathrm{MHz}, \mathrm{CDCl}_{3}, 25{ }^{\circ} \mathrm{C}\right): \delta=-0.4$ (s) ppm; elemental analysis (\%): calcd for $\mathrm{C}_{62} \mathrm{H}_{94} \mathrm{O}_{26} \mathrm{P}_{2} \mathrm{PdCl}_{2} \bullet 0.5 \mathrm{CH}_{2} \mathrm{Cl}_{2}(1494.68+42.47)$ : $\mathrm{C} 48.84$, H 6.23; found: C 48.73, H, 6.30; MS (Maldi TOF): $m / z$ (\%): 1494.1 (19) [M] $]^{+} 1459.1$ (70) [M $-\mathrm{Cl}]^{+}, 1422.2(100)[M-2 \mathrm{Cl}]^{+}$.

Trans-P,P'-dichloro- $\left\{6^{\mathrm{A}}, 6^{\mathrm{B}}, 6^{\mathrm{D}}, 6^{\mathrm{E}}\right.$-tetradeoxy-6 $6^{\mathrm{A}}, 6^{\mathrm{B}}: 6^{\mathrm{D}}, 6^{\mathrm{E}}$-bis $[(R)$-phenylphosphinidene $]-$ $2^{\mathrm{A}}, 2^{\mathrm{B}}, 2^{\mathrm{C}}, 2^{\mathrm{D}}, 2^{\mathrm{E}}, 2^{\mathrm{F}}, 3^{\mathrm{A}}, 3^{\mathrm{B}}, 3^{\mathrm{C}}, 3^{\mathrm{D}}, 3^{\mathrm{E}}, 3^{\mathrm{F}}, 6^{\mathrm{C}}, 6^{\mathrm{F}}$-tetradeca- $O$-methyl- $\alpha$-cyclodextrin $\}$ nickel(II)

(7): A suspension of $\mathrm{NiCl}_{2}(0.018 \mathrm{~g}, 0.14 \mathrm{mmol})$ in ethanol $(2 \mathrm{~mL})$ was added to a solution of TRANSDIP $(0.180 \mathrm{~g}, 0.14 \mathrm{mmol})$ in $\mathrm{CH}_{2} \mathrm{Cl}_{2}(10 \mathrm{~mL})$, under vigorous stirring. After 4 hours at $25^{\circ} \mathrm{C}$ the solvent was evaporated, whereupon the product was dissolved in $\mathrm{CH}_{2} \mathrm{Cl}_{2}(5 \mathrm{~mL})$ and pentane $(150 \mathrm{~mL})$ was added to precipitate unreacted compounds, which were then filtered off over Celite. Evaporation of pentane afforded 7 as a violet powder (yield $0.183 \mathrm{~g}$, 93\%). $R_{\mathrm{f}}\left(\mathrm{SiO}_{2}, \mathrm{CH}_{2} \mathrm{Cl}_{2} / \mathrm{MeOH}, 90: 10, \mathrm{v} / \mathrm{v}\right)=0.41 ; \mathrm{Mp} 193{ }^{\circ} \mathrm{C}$ dec. ${ }^{1} \mathrm{H}$ NMR $(300.1 \mathrm{MHz}$, $\left.\mathrm{CDCl}_{3}, 25^{\circ} \mathrm{C}\right): \delta($ assignment by COSY $)=1.92\left(\mathrm{~m}, 2 \mathrm{H}, \mathrm{H}-6 \mathrm{a}^{\mathrm{A}, \mathrm{D}}\right.$ or B,E$), 2.49\left(\mathrm{~m}, 2 \mathrm{H}, \mathrm{H}-6 \mathrm{a}^{\mathrm{B}, \mathrm{E}}\right.$ or A,D $), 2.64\left(\mathrm{~m}, 2 \mathrm{H}, \mathrm{H}-6 \mathrm{~b}^{\mathrm{B}, \mathrm{E} \text { or A,D }}\right), 3.05-3.31\left(12 \mathrm{H}, \mathrm{H}-2, \mathrm{H}-4^{\mathrm{A}, \mathrm{B}, \mathrm{D}, \mathrm{E}}, \mathrm{H}-6 \mathrm{~b}^{\mathrm{A}, \mathrm{D} \text { or B,E }}\right), 3.40-3.79$ $\left(8 \mathrm{H}, \mathrm{H}-3, \mathrm{H}-6 \mathrm{a}^{\mathrm{C}, \mathrm{F}}\right), 3.43$ (s, $\left.6 \mathrm{H}, \mathrm{OMe}\right), 3.49$ (s, $\left.6 \mathrm{H}, \mathrm{OMe}\right), 3.52$ (s, $\left.6 \mathrm{H}, \mathrm{OMe}\right), 3.56$ (s, $6 \mathrm{H}$, OMe), 3.64 (s, $6 \mathrm{H}, \mathrm{OMe}$ ), 3.65 (s, $6 \mathrm{H}, \mathrm{OMe}$ ), 3.79 (s, $6 \mathrm{H}, \mathrm{OMe}), 3.92$ (virtual t, $2 \mathrm{H},{ }^{3} J_{\mathrm{H}-4, \mathrm{H}-}$ $\left.{ }_{3}={ }^{3} J_{\mathrm{H}-4, \mathrm{H}-5}=9.0 \mathrm{~Hz}, \mathrm{H}-4^{\mathrm{C}, \mathrm{F}}\right), 4.36\left(\mathrm{~m}, 2 \mathrm{H}, \mathrm{H}-5^{\mathrm{A}, \mathrm{D}}\right.$ or B,E $), 4.44\left(\mathrm{~m}, 2 \mathrm{H}, \mathrm{H}-6 \mathrm{~b}^{\mathrm{C}, \mathrm{F}}\right), 4.69(\mathrm{~m}, 2$ $\left.\mathrm{H}, \mathrm{H}-5^{\mathrm{C}, \mathrm{F}}\right), 4.98$ (two overlapping d, $\left.4 \mathrm{H}, \mathrm{H}-1^{\mathrm{A}, \mathrm{B}, \mathrm{D}, \mathrm{E}}\right), 5.08\left(\mathrm{~m}, 2 \mathrm{H}, \mathrm{H}-5^{\mathrm{B}, \mathrm{E} \text { or A,D }}\right), 5.11(\mathrm{~d}, 2 \mathrm{H}$, $\left.{ }^{3} J_{\mathrm{H}-1, \mathrm{H}-2}=3.6 \mathrm{~Hz}, \mathrm{H}-1^{\mathrm{C}, \mathrm{F}}\right), 5.35\left(\mathrm{~m}, 2 \mathrm{H}, \mathrm{H}-5^{\mathrm{B}, \mathrm{E}}\right.$ or A,D $), 7.37-7.39(6 \mathrm{H}, m-\mathrm{H}, p-\mathrm{H}), 8.02(\mathrm{~m}, 4$ $\mathrm{H}, o-\mathrm{H}) \mathrm{ppm} ;{ }^{13} \mathrm{C}\left\{{ }^{1} \mathrm{H}\right\} \mathrm{NMR}\left(75.5 \mathrm{MHz}, \mathrm{CDCl}_{3}, 25{ }^{\circ} \mathrm{C}\right): \delta$ (assignment by HMQC) $=27.0$ (virtual t, $\left.\left|{ }^{1} J_{\mathrm{C}, \mathrm{P}}+{ }^{3} J_{\mathrm{C}, \mathrm{P}}{ }^{\prime}\right|=18.1 \mathrm{~Hz}, \mathrm{C}-6^{\mathrm{A}, \mathrm{D} \text { or B,E}}\right), 34.8\left(\mathrm{~m}, \mathrm{C}-6^{\mathrm{B}, \mathrm{E}}\right.$ or A,D $), 56.9,57.8,58.8,58.8$, 61.1, 61.3, $61.4\left(2-\mathrm{OCH}_{3}, 3-\mathrm{OCH}_{3}, 6-\mathrm{OCH}_{3}\right), 64.8\left(\mathrm{C}-5^{\mathrm{A}, \mathrm{D} \text { or B,E}}\right), 68.2\left(\mathrm{C}-5^{\mathrm{B}, \mathrm{E} \text { or A,D}}\right), 70.7(\mathrm{C}-$ $\left.5^{\mathrm{C}, \mathrm{F}}\right), 71.9\left(\mathrm{C}-6^{\mathrm{C}, \mathrm{F}}\right), 79.9,80.8,81.0,81.1,81.2,82.9,83.0,85.0,89.5$ (C-2, C-3, C-4), 96.6 $\left(\mathrm{C}-1^{\mathrm{B}, \mathrm{E} \text { or A,D }}\right), 97.1\left(\mathrm{C}-1^{\mathrm{A}, \mathrm{D} \text { or B,E}}\right), 100.5\left(\mathrm{C}-1^{\mathrm{C}, \mathrm{F}}\right), 127.9(m-\mathrm{C}, p-\mathrm{C}), 129.5$ (o-C), 131.6 (ipsoC) $\mathrm{ppm} ;{ }^{31} \mathrm{P}\left\{{ }^{1} \mathrm{H}\right\} \mathrm{NMR}\left(121.5 \mathrm{MHz}, \mathrm{CDCl}_{3}, 25^{\circ} \mathrm{C}\right): \delta=-9.5$ (s) ppm; elemental analysis (\%): calcd for $\mathrm{C}_{62} \mathrm{H}_{94} \mathrm{Cl}_{2} \mathrm{NiO}_{26} \mathrm{P}_{2} \cdot \mathrm{CH}_{2} \mathrm{Cl}_{2}(1446.98+84.93)$ : C 49.40, H 6.32; found: $\mathrm{C} 49.59, \mathrm{H}$ 6.69; MS (ESI-TOF): $m / z(\%): 1481.4(100)[M+\mathrm{Cl}]^{-}$.

Trans- $P, P^{\prime}$-dibromo- $\left\{6^{\mathrm{A}}, 6^{\mathrm{B}}, 6^{\mathrm{D}}, 6^{\mathrm{E}}\right.$-tetradeoxy- $6^{\mathrm{A}}, 6^{\mathrm{B}}: 6^{\mathrm{D}}, 6^{\mathrm{E}}$-bis $[(R)$-phenylphosphinidene $]-$ $2^{\mathrm{A}}, 2^{\mathrm{B}}, 2^{\mathrm{C}}, 2^{\mathrm{D}}, 2^{\mathrm{E}}, 2^{\mathrm{F}}, 3^{\mathrm{A}}, 3^{\mathrm{B}}, 3^{\mathrm{C}}, 3^{\mathrm{D}}, 3^{\mathrm{E}}, 3^{\mathrm{F}}, 6^{\mathrm{C}}, 6^{\mathrm{F}}$-tetradeca- $O$-methyl- $\alpha$-cyclodextrin $\}$ nickel(II)

(8): A suspension of $\mathrm{NiBr}_{2}(0.030 \mathrm{~g}, 0.14 \mathrm{mmol})$ in ethanol $(2 \mathrm{~mL})$ was added to a solution of TRANSDIP $(0.180 \mathrm{~g}, 0.14 \mathrm{mmol})$ in $\mathrm{CH}_{2} \mathrm{Cl}_{2}(10 \mathrm{~mL})$, under vigorous stirring. After 4 hours 
at $25^{\circ} \mathrm{C}$ the solvent was evaporated, whereupon the product was dissolved in $\mathrm{CH}_{2} \mathrm{Cl}_{2}(5 \mathrm{~mL})$ and pentane $(150 \mathrm{~mL})$ was added to precipitate unreacted compounds, which were then filtered off over Celite. Evaporation of pentane afforded 8 as a green powder (yield $0.175 \mathrm{~g}$, 83\%). $R_{\mathrm{f}}\left(\mathrm{SiO}_{2}, \mathrm{CH}_{2} \mathrm{Cl}_{2} / \mathrm{MeOH}, 90: 10, \mathrm{v} / \mathrm{v}\right)=0.38 ; \mathrm{Mp} 186^{\circ} \mathrm{C}$ dec. ${ }^{1} \mathrm{H}$ NMR $(300.1 \mathrm{MHz}$, $\left.\mathrm{CDCl}_{3}, 25^{\circ} \mathrm{C}\right): \delta($ assignment by COSY $)=2.09\left(\mathrm{~m}, 2 \mathrm{H}, \mathrm{H}-6 \mathrm{a}^{\mathrm{A}, \mathrm{D}}\right.$ or B,E$), 2.54\left(\mathrm{~m}, 2 \mathrm{H}, \mathrm{H}-6 \mathrm{a}^{\mathrm{B}, \mathrm{E}}\right.$ or A,D), 2.84 (m, 2 H, H-6b ${ }^{\mathrm{B}, \mathrm{E}}$ or A,D $)$, 3.04-3.28 (10 H, H-2, H-4 $\left.4^{\mathrm{A}, \mathrm{B}, \mathrm{D}, \mathrm{E}}\right), 3.33$ (m, $2 \mathrm{H}, \mathrm{H}-6 \mathrm{~b}^{\mathrm{A}, \mathrm{D} \text { or }}$ B,E), 3.45-3.70 (6 H, H-3), 3.48 (s, $6 \mathrm{H}, \mathrm{OMe}), 3.53$ (s, $6 \mathrm{H}, \mathrm{OMe}), 3.56$ (s, $6 \mathrm{H}, \mathrm{OMe}), 3.58$ (s, $6 \mathrm{H}, \mathrm{OMe}), 3.66$ (s, $6 \mathrm{H}, \mathrm{OMe}), 3.68$ (s, $6 \mathrm{H}, \mathrm{OMe}), 3.81$ (s, $6 \mathrm{H}, \mathrm{OMe}), 3.90-4.01(4 \mathrm{H}, \mathrm{H}-$ $\left.4^{\mathrm{C}, \mathrm{F}}, \mathrm{H}-6 \mathrm{a}^{\mathrm{C}, \mathrm{F}}\right), 4.49$ (m, $\left.2 \mathrm{H}, \mathrm{H}-5^{\mathrm{A}, \mathrm{D} \text { or B,E }}\right), 4.74$ (m, $\left.2 \mathrm{H}, \mathrm{H}-6 \mathrm{~b}^{\mathrm{C}, \mathrm{F}}\right), 4.86$ (m, $\left.2 \mathrm{H}, \mathrm{H}-5^{\mathrm{C}, \mathrm{F}}\right), 4.97$ $\left(\mathrm{d}, 2 \mathrm{H},{ }^{3} J_{\mathrm{H}-1, \mathrm{H}-2}=4.1 \mathrm{~Hz}, \mathrm{H}-1^{\mathrm{A}, \mathrm{D} \text { or B,E}}\right), 5.10$ (two overlapping d, $\left.4 \mathrm{H}, \mathrm{H}-1^{\mathrm{B}, \mathrm{E} \text { or A,D }}, \mathrm{H}-1^{\mathrm{C}, \mathrm{F}}\right)$, $5.35\left(\mathrm{~m}, 2 \mathrm{H}, \mathrm{H}-5^{\mathrm{B}, \mathrm{E}}\right.$ or A,D $), 7.36-7.41(6 \mathrm{H}, m-\mathrm{H}, p-\mathrm{H}), 7.81(\mathrm{~m}, 4 \mathrm{H}, o-\mathrm{H}) \mathrm{ppm} ;{ }^{13} \mathrm{C}\left\{{ }^{1} \mathrm{H}\right\}$ $\operatorname{NMR}\left(75.5 \mathrm{MHz}, \mathrm{CDCl}_{3}, 25{ }^{\circ} \mathrm{C}\right): \delta$ (assignment by HMQC) $=28.4$ (virtual t, $\left|{ }^{1} J_{\mathrm{C}, \mathrm{P}}+{ }^{3} J_{\mathrm{C}, \mathrm{P}^{\prime}}\right|=$ $\left.17.6 \mathrm{~Hz}, \mathrm{C}-6^{\mathrm{A}, \mathrm{D} \text { or B,E}}\right), 35.1$ (C-6 $\left.\mathrm{B}^{\mathrm{B}, \mathrm{E} \text { or A,D}}\right), 56.2,57.2,58.2,58.3,60.5,60.7,61.0\left(2-\mathrm{OCH}_{3}, 3-\right.$ $\left.\mathrm{OCH}_{3}, 6-\mathrm{OCH}_{3}\right), 65.0\left(\mathrm{C}-5^{\mathrm{A}, \mathrm{D} \text { or B,E }}\right), 67.4\left(\mathrm{C}-5^{\mathrm{B}, \mathrm{E}}\right.$ or A,D $), 69.9\left(\mathrm{C}-5^{\mathrm{C}, \mathrm{F}}\right), 71.4\left(\mathrm{C}-6^{\mathrm{C}, \mathrm{F}}\right), 79.7$, 80.3, 80.4, 80.5, 80.5, 82.3, 82.4, 84.5, 88.8 (C-2, C-3, C-4), $96.1\left(\mathrm{C}-1^{\mathrm{B}, \mathrm{E}}\right.$ or A,D $), 96.4\left(\mathrm{C}-1^{\mathrm{A}, \mathrm{D}}\right.$ or $\mathrm{B}, \mathrm{E}), 99.8\left(\mathrm{C}-1^{\mathrm{C}, \mathrm{F}}\right), 127.0(m-\mathrm{C}), 128.6(p-\mathrm{C}), 130.6(o-\mathrm{C}), 136.4$ (ipso-C) ppm; ${ }^{31} \mathrm{P}\left\{{ }^{1} \mathrm{H}\right\}$ $\operatorname{NMR}\left(121.5 \mathrm{MHz}, \mathrm{CDCl}_{3}, 25^{\circ} \mathrm{C}\right): \delta=-6.9$ (s) ppm; elemental analysis (\%): calcd for $\mathrm{C}_{62} \mathrm{H}_{94} \mathrm{Br}_{2} \mathrm{NiO}_{26} \mathrm{P}_{2} \cdot 2\left(\mathrm{CH}_{2} \mathrm{Cl}_{2}\right)(1535.84+169.87)$ : $\mathrm{C}$ 45.07, $\mathrm{H}$ 5.79; found: $\mathrm{C} 44.81, \mathrm{H}$ 5.92; MS (ESI-TOF): $m / z(\%): 1525.3(16)[M-\mathrm{Br}+2 \mathrm{Cl}]^{-}, 1571.3(73)[M+\mathrm{Cl}]^{-}, 1615.2(100)$ $[M+\mathrm{Br}]^{-}$.

Trans-P,P'-chloro-methyl- $\left\{6^{\mathrm{A}}, 6^{\mathrm{B}}, 6^{\mathrm{D}}, 6^{\mathrm{E}}\right.$-tetradeoxy- $6^{\mathrm{A}}, 6^{\mathrm{B}}: 6^{\mathrm{D}}, 6^{\mathrm{E}}$-bis $[(R)$-phenylphosphini dene $]-2^{\mathrm{A}}, 2^{\mathrm{B}}, 2^{\mathrm{C}}, 2^{\mathrm{D}}, 2^{\mathrm{E}}, 2^{\mathrm{F}}, 3^{\mathrm{A}}, 3^{\mathrm{B}}, 3^{\mathrm{C}}, 3^{\mathrm{D}}, 3^{\mathrm{E}}, 3^{\mathrm{F}}, 6^{\mathrm{C}}, 6^{\mathrm{F}}$-tetradeca- $O$-methyl- $\alpha$-cyclodextrin $\}$ palla dium(II) (9): A solution of [PdClMe(1,5-cyclooctadiene)] (0.024 g, $0.08 \mathrm{mmol})$ in $\mathrm{CH}_{2} \mathrm{Cl}_{2}(3$ $\mathrm{mL})$ was added to a solution of TRANSDIP $(0.110 \mathrm{~g}, 0.08 \mathrm{mmol})$ in $\mathrm{CH}_{2} \mathrm{Cl}_{2}(20 \mathrm{~mL})$ under vigorous stirring. After stirring for $14 \mathrm{~h}$, the solution was concentrated to $5 \mathrm{~mL}$ and pentane $(120 \mathrm{~mL})$ was added. Filtration through Celite and subsequent precipitation afforded pure 9 as a pale yellow powder (yield $0.117 \mathrm{~g}, 95 \%$ ). $R_{\mathrm{f}}\left(\mathrm{SiO}_{2}, \mathrm{CH}_{2} \mathrm{Cl}_{2} / \mathrm{MeOH}, 90: 10\right.$, v/v) $=0.45 ; \mathrm{Mp}$ 198-201 ${ }^{\circ} \mathrm{C} .{ }^{1} \mathrm{H}$ NMR $\left(500.1 \mathrm{MHz}, \mathrm{CDCl}_{3}, 25^{\circ} \mathrm{C}\right): \delta$ (assignment by COSY and ROESY) $=-$ $0.68\left(\mathrm{t}, 3 \mathrm{H},{ }^{3} J_{\mathrm{H}, \mathrm{P}}=6.8 \mathrm{~Hz}, \mathrm{CH}_{3}\right), 2.07\left(\mathrm{~m}, 2 \mathrm{H}, \mathrm{H}-6 \mathrm{a}^{\mathrm{A}, \mathrm{D} \text { or B,E}}\right), 2.37\left(\mathrm{~m}, 2 \mathrm{H}, \mathrm{H}-6 \mathrm{a}^{\mathrm{B}, \mathrm{E} \text { or A,D}}\right)$, 3.06-3.20 (10 H, H-2, H-4 $\left.4^{\mathrm{A}, \mathrm{B}, \mathrm{D}, \mathrm{E}}\right), 3.23$ (m, H-6b $\left.\mathrm{b}^{\mathrm{A}, \mathrm{D} \text { or B,E }}\right), 3.32\left(\mathrm{~m}, 2 \mathrm{H}, \mathrm{H}-6 \mathrm{~b}^{\mathrm{B}, \mathrm{E} \text { or A,D}}\right), 3.39$ (s, $6 \mathrm{H}, \mathrm{OMe}), 3.46-3.71\left(8 \mathrm{H}, \mathrm{H}-3, \mathrm{H}-6 \mathrm{a}^{\mathrm{C}, \mathrm{F}}\right), 3.46$ (s, $\left.6 \mathrm{H}, \mathrm{OMe}\right), 3.49$ (s, $\left.6 \mathrm{H}, \mathrm{OMe}\right), 3.50$ (s, 6 $\mathrm{H}, \mathrm{OMe}$ ), 3.63 (s, 6 H, OMe), 3.64 (s, $6 \mathrm{H}, \mathrm{OMe}), 3.70$ (s, $6 \mathrm{H}, \mathrm{OMe}), 3.78$ (virtual triplet, 2 $\left.\mathrm{H},{ }^{3} J_{\mathrm{H}-4, \mathrm{H}-3}={ }^{3} J_{\mathrm{H}-4, \mathrm{H}-5}=9.0 \mathrm{~Hz}, \mathrm{H}-4{ }^{\mathrm{C}, \mathrm{F}}\right), 4.47\left(\mathrm{dd}, 2 \mathrm{H},{ }^{3} J_{\mathrm{H}-6 \mathrm{~b}, \mathrm{H}-5}=2.9 \mathrm{~Hz},{ }^{2} J_{\mathrm{H}-6 \mathrm{~b}, \mathrm{H}-6 \mathrm{a}}=10.8 \mathrm{~Hz}\right.$, 
H-6b $\left.{ }^{\mathrm{C}, \mathrm{F}}\right), 4.70-4.76\left(4 \mathrm{H}, \mathrm{H}-5^{\mathrm{A}, \mathrm{D} \text { or B,E}}, \mathrm{H}-5^{\mathrm{C}, \mathrm{F}}\right), 4.91\left(\mathrm{~d}, 2 \mathrm{H},{ }^{3} J_{\mathrm{H}-1, \mathrm{H}-2}=4.3 \mathrm{~Hz}, \mathrm{H}-1^{\mathrm{A}, \mathrm{D} \text { or B,E}}\right)$, $5.01\left(\mathrm{~d}, 2 \mathrm{H},{ }^{3} J_{\mathrm{H}-1, \mathrm{H}-2}=3.6 \mathrm{~Hz}, \mathrm{H}-1^{\mathrm{C}, \mathrm{F}}\right), 5.03\left(\mathrm{~d}, 2 \mathrm{H},{ }^{3} J_{\mathrm{H}-1, \mathrm{H}-2}=3.3 \mathrm{~Hz}, \mathrm{H}-1^{\mathrm{B}, \mathrm{E}}\right.$ or A,D $), 5.40(\mathrm{~m}$, $\left.2 \mathrm{H}, \mathrm{H}-5^{\mathrm{B}, \mathrm{E} \text { or A,D }}\right), 7.29(\mathrm{~m}, 2 \mathrm{H}, p-\mathrm{H}), 7.34(\mathrm{~m}, 4 \mathrm{H}, m-\mathrm{H}), 7.40(\mathrm{~m}, 4 \mathrm{H}, o-\mathrm{H}) \mathrm{ppm} ;{ }^{13} \mathrm{C}\left\{{ }^{1} \mathrm{H}\right\}$ NMR $\left(125.8 \mathrm{MHz}, \mathrm{CDCl}_{3}, 25{ }^{\circ} \mathrm{C}\right): \delta$ (assignment by $\left.\mathrm{HMQC}\right)=6.2$ (br signal with triplet shape, $\mathrm{CH}_{3}$ ), 29.4 (virtual t, $\left.\left|{ }^{1} J_{\mathrm{C}, \mathrm{P}}+{ }^{3} J_{\mathrm{C}, \mathrm{P}}\right|=22.0, \mathrm{C}-6^{\mathrm{A}, \mathrm{D} \text { or B,E}}\right), 35.8$ (virtual t, $\left|{ }^{1} J_{\mathrm{C}, \mathrm{P}}+{ }^{3} J_{\mathrm{C}, \mathrm{P}}{ }^{\prime}\right|=$ $\left.18.5 \mathrm{~Hz}, \mathrm{C}-6^{\mathrm{B}, \mathrm{E} \text { or A,D }}\right), 57.5,57.8,58.3\left(2-\mathrm{OCH}_{3}\right), 59.2\left(6-\mathrm{OCH}_{3}\right), 61.7,61.8,62.1\left(3-\mathrm{OCH}_{3}\right)$, 65.7 (br signal with triplet shape, C-5 $5^{\mathrm{A}, \mathrm{D} \text { or B,E }}$ ), 68.3 (virtual t, $\left.\right|^{2} J_{\mathrm{C}, \mathrm{P}}+{ }^{4} J_{\mathrm{C}, \mathrm{P}^{\prime}} \mid=9.0 \mathrm{~Hz}, \mathrm{C}-5^{\mathrm{B}, \mathrm{E} \text { or }}$ $\left.{ }^{\mathrm{A}, \mathrm{D}}\right), 70.3\left(\mathrm{C}-5^{\mathrm{C}, \mathrm{F}}\right), 72.0\left(\mathrm{C}-6^{\mathrm{C}, \mathrm{F}}\right), 81.0[\times 2]\left(\mathrm{C}-3^{\mathrm{B}, \mathrm{E} \text { or A,D }}, \mathrm{C}-3^{\mathrm{C}, \mathrm{F}}\right), 81.3\left(\mathrm{C}-4^{\mathrm{C}, \mathrm{F}}\right), 81.4\left(\mathrm{C}-2^{\mathrm{B}, \mathrm{E} \text { or }}\right.$ $\left.{ }^{\mathrm{A}, \mathrm{D}}\right), 81.7\left(\mathrm{C}-2^{\mathrm{C}, \mathrm{F}}\right), 82.8\left(\mathrm{C}-3^{\mathrm{A}, \mathrm{D} \text { or B,E}}\right), 83.2\left(\mathrm{C}-2^{\mathrm{A}, \mathrm{D} \text { or B,E}}\right), 87.4$ (virtual t, $\left.\right|^{3} J_{\mathrm{C}, \mathrm{P}}+{ }^{5} J_{\mathrm{C}, \mathrm{P}} \mid=9.0$ $\left.\mathrm{Hz}, \mathrm{C}-4^{\mathrm{A}, \mathrm{D} \text { or B,E}}\right), 89.9\left(\mathrm{C}-4^{\mathrm{B}, \mathrm{E}}\right.$ or A,D $), 97.6\left(\mathrm{C}-1^{\mathrm{A}, \mathrm{D} \text { or B,E}}\right), 98.0\left(\mathrm{C}-1^{\mathrm{B}, \mathrm{E} \text { or A,D }}\right), 101.0\left(\mathrm{C}-1^{\mathrm{C}, \mathrm{F}}\right)$, 128.3 (virtual t, $\left.\left|{ }^{3} J_{\mathrm{C}, \mathrm{P}}+{ }^{5} J_{\mathrm{C}, \mathrm{P}}\right|=9.0 \mathrm{~Hz}, m-\mathrm{C}\right), 129.2(p-\mathrm{C}), 130.6$ (virtual t, $\left.\right|^{2} J_{\mathrm{C}, \mathrm{P}}+{ }^{4} J_{\mathrm{C}, \mathrm{P}}{ }^{\prime} \mid=$ $10.0 \mathrm{~Hz}, o-\mathrm{C}), 135.4$ (virtual t, $\left|{ }^{1} J_{\mathrm{C}, \mathrm{P}}+{ }^{3} J_{\mathrm{C}, \mathrm{P}}\right|=42.5 \mathrm{~Hz}$, ipso-C) ppm; ${ }^{31} \mathrm{P}\left\{{ }^{1} \mathrm{H}\right\} \mathrm{NMR}(121.5$ $\mathrm{MHz}, \mathrm{CDCl}_{3}, 25^{\circ} \mathrm{C}$ ): $\delta=3.8$ (s) ppm; elemental analysis (\%): clacd for $\mathrm{C}_{63} \mathrm{H}_{97} \mathrm{ClO}_{26} \mathrm{P}_{2} \mathrm{Pd}$ (1474.26): C 51.33, H 6.63; found: C 51.50, H 6.69; MS (Maldi TOF): $m / z$ (\%): 1474.1 (6) $[M]^{+}, 1459.1(22)[M-\mathrm{Me}]^{+}, 1437.2(15)[M-\mathrm{Cl}]^{+}, 1422(66)[M-\mathrm{Me}-\mathrm{Cl}]^{+}$.

Trans-P,P'-methyl- $\left\{6^{\mathrm{A}}, 6^{\mathrm{B}}, 6^{\mathrm{D}}, 6^{\mathrm{E}}\right.$-tetradeoxy- $6^{\mathrm{A}}, 6^{\mathrm{B}}: 6^{\mathrm{D}}, 6^{\mathrm{E}}$-bis $[(R)$-phenylphosphinidene $]-$ $2^{\mathrm{A}}, 2^{\mathrm{B}}, 2^{\mathrm{C}}, 2^{\mathrm{D}}, 2^{\mathrm{E}}, 2^{\mathrm{F}}, 3^{\mathrm{A}}, 3^{\mathrm{B}}, 3^{\mathrm{C}}, 3^{\mathrm{D}}, 3^{\mathrm{E}}, 3^{\mathrm{F}}, 6^{\mathrm{C}}, 6^{\mathrm{F}}$-tetradeca- $O$-methyl- $\alpha$-cyclodextrin $\}$ (pyridine) palladium(II)tetrafluoroborate (10): A solution of $\mathrm{AgBF}_{4}(0.024 \mathrm{~g}, 0.12 \mathrm{mmol})$ in THF (1 $\mathrm{mL})$ was added to a solution of $[\mathrm{PdClMe}(\mathrm{COD})](0.032 \mathrm{~g}, 0.12 \mathrm{mmol})$ in $\mathrm{CH}_{2} \mathrm{Cl}_{2}(3 \mathrm{~mL})$. After stirring the suspension vigorously for $5 \mathrm{~min}$, the precipitate was collected on Celite and the filtrate directly added to a solution of TRANSDIP $(0.169 \mathrm{~g}, 0.12 \mathrm{mmol})$ in $\mathrm{CH}_{2} \mathrm{Cl}_{2} /$ pyridine $(83: 17, \mathrm{v} / \mathrm{v}, 12 \mathrm{~mL})$ under agitation at $0^{\circ} \mathrm{C}$. The reaction mixture was then stirred at room temperature for $30 \mathrm{~min}$. before being concentrated to $c a$. $5 \mathrm{~mL}$. Addition of pentane $(80 \mathrm{~mL})$ caused the product to precipitate and filtration through a Schlenk type fritté afforded pure 10 as a pale yellow solid (yield $0.170 \mathrm{~g}, 96 \%$ ). Complex 10 decomposes on silica $\left(\mathrm{SiO}_{2}\right)$; $\mathrm{Mp} 183{ }^{\circ} \mathrm{C}$ dec. ${ }^{1} \mathrm{H} \mathrm{NMR}\left(300.1 \mathrm{MHz},\left(\mathrm{CD}_{3}\right)_{2} \mathrm{CO}, 25^{\circ} \mathrm{C}\right): \delta$ (assignment by COSY and ROESY) $=1.12\left(\mathrm{t}, 3 \mathrm{H},{ }^{3} J_{\mathrm{H}, \mathrm{P}}=7.3 \mathrm{~Hz}, \mathrm{CH}_{3}\right), 2.21\left(\mathrm{~m}, 2 \mathrm{H}, \mathrm{H}-6 \mathrm{a}^{\mathrm{A}, \mathrm{D} \text { or B,E}}\right), 2.86(\mathrm{~m}$, $2 \mathrm{H}, \mathrm{H}-6 \mathrm{a}^{\mathrm{B}, \mathrm{E}}$ or A,D $), 3.14-3.87$ (22 H, H-2, H-3, H-4, H-6b $\left.{ }^{\mathrm{A}, \mathrm{B}, \mathrm{D}, \mathrm{E}}\right), 3.47$ (s, $\left.6 \mathrm{H}, 6-\mathrm{OMe}\right), 3.55$ (s, $6 \mathrm{H}, \mathrm{OMe}), 3.55(\mathrm{~s}, 6 \mathrm{H}, \mathrm{OMe}), 3.56(\mathrm{~s}, 6 \mathrm{H}, \mathrm{OMe}), 3.60(\mathrm{~s}, 6 \mathrm{H}, \mathrm{OMe}), 3.65(\mathrm{~s}, 6 \mathrm{H}$, $\mathrm{OMe}), 3.71$ (s, $6 \mathrm{H}, \mathrm{OMe}), 4.07$ (m, $\left.2 \mathrm{H}, \mathrm{H}-6 \mathrm{a}^{\mathrm{C}, \mathrm{F}}\right), 4.24-4.44\left(6 \mathrm{H}, \mathrm{H}-5^{\mathrm{A}, \mathrm{D} \text { or B,E }}, \mathrm{H}-5^{\mathrm{C}, \mathrm{F}}, \mathrm{H}-\right.$ $\left.6 \mathrm{~b}^{\mathrm{C}, \mathrm{F}}\right), 4.84\left(\mathrm{~m}, 2 \mathrm{H}, \mathrm{H}-5^{\mathrm{B}, \mathrm{E}}\right.$ or A,D $), 5.10\left(\mathrm{~d}, 2 \mathrm{H},{ }^{3} J_{\mathrm{H}-1, \mathrm{H}-2}=4.5 \mathrm{~Hz}, \mathrm{H}-1^{\mathrm{A}, \mathrm{D}}\right.$ or B,E $), 5.11(\mathrm{~d}, 2 \mathrm{H}$, $\left.{ }^{3} J_{\mathrm{H}-1, \mathrm{H}-2}=4.4 \mathrm{~Hz}, \mathrm{H}-1^{\mathrm{C}, \mathrm{F}}\right), 5.26\left(\mathrm{~d}, 2 \mathrm{H},{ }^{3} J_{\mathrm{H}-1, \mathrm{H}-2}=3.1 \mathrm{~Hz}, \mathrm{H}-1^{\mathrm{B}, \mathrm{E}}\right.$ or A,D $), 6.70(\mathrm{~m}, 2 \mathrm{H}, m-\mathrm{H}$ of M-pyridine), 7.04-7.69 (11 H, p-H of M-pyridine, aromatic H of P-phenyl), 7.74 (m, $2 \mathrm{H}, o-\mathrm{H}$ 
of M-pyridine) ppm, small amounts of free pyridine were also detected; ${ }^{13} \mathrm{C}\left\{{ }^{1} \mathrm{H}\right\}$ NMR $(125.8$ $\left.\mathrm{MHz},\left(\mathrm{CD}_{3}\right)_{2} \mathrm{CO}, 25^{\circ} \mathrm{C}\right): \delta$ (assignment by HMQC) $=29.7\left(\mathrm{~m}, \mathrm{C}-6^{\mathrm{A}, \mathrm{D} \text { or B,E}}\right), 34.7\left(\mathrm{~m}, \mathrm{C}-6^{\mathrm{B}, \mathrm{E}}\right.$ or $\left.{ }^{\mathrm{A}, \mathrm{D}}\right), 57.4,58.6,59.5,60.2,61.6,61.7,61.8\left(2-\mathrm{OCH}_{3}, 3-\mathrm{OCH}_{3}, 6-\mathrm{OCH}_{3}\right), 66.7\left(\mathrm{C}-5^{\mathrm{A}, \mathrm{D} \text { or B,E}}\right)$, $68.1\left(\mathrm{C}-5^{\mathrm{C}, \mathrm{F}}\right), 69.5\left(\mathrm{C}-5^{\mathrm{B}, \mathrm{E}}\right.$ or A,D $), 72.9\left(\mathrm{C}-6^{\mathrm{C}, \mathrm{F}}\right), 81.4,82.1,82.2,82.3,82.4,83.9,84.3,85.8$, $89.7(\mathrm{C}-2, \mathrm{C}-3, \mathrm{C}-4), 97.8\left(\mathrm{C}-1^{\mathrm{A}, \mathrm{D}}\right.$ or B,E$), 98.1\left(\mathrm{C}-1^{\mathrm{B}, \mathrm{E}}\right.$ or $\left.\mathrm{A}, \mathrm{D}\right), 101.3\left(\mathrm{C}-1^{\mathrm{C}, \mathrm{F}}\right), 126.2-132.6$ (aromatic C) ppm; ${ }^{31} \mathrm{P}\left\{{ }^{1} \mathrm{H}\right\} \mathrm{NMR}\left(121.5 \mathrm{MHz},\left(\mathrm{CD}_{3}\right)_{2} \mathrm{CO}, 25^{\circ} \mathrm{C}\right): \delta=-7.1$ (s) ppm; $\mathrm{C}_{63} \mathrm{H}_{97} \mathrm{ClO}_{26} \mathrm{P}_{2} \mathrm{Pd}$ (1474.26); MS (ESI-TOF): $m / z$ (\%): 1437.5 (100) $\left[M-\mathrm{BF}_{4}-\text { py] }\right]^{+}$. We do not provide microanalytical data for the cationic palladium(II) complexes reported in this study since this species was obtained only in the presence of excess pyridine.

Trans- $P, P^{\prime}$-chloro-carbonyl- $\left\{6^{\mathrm{A}}, 6^{\mathrm{B}}, 6^{\mathrm{D}}, 6^{\mathrm{E}}\right.$-tetradeoxy- $6^{\mathrm{A}}, 6^{\mathrm{B}}: 6^{\mathrm{D}}, 6^{\mathrm{E}}$-bis $[(R)$-phenylphosphini dene $]-2^{\mathrm{A}}, 2^{\mathrm{B}}, 2^{\mathrm{C}}, 2^{\mathrm{D}}, 2^{\mathrm{E}}, 2^{\mathrm{F}}, 3^{\mathrm{A}}, 3^{\mathrm{B}}, 3^{\mathrm{C}}, 3^{\mathrm{D}}, 3^{\mathrm{E}}, 3^{\mathrm{F}}, 6^{\mathrm{C}}, 6^{\mathrm{F}}$-tetradeca- $O$-methyl- $\alpha$-cyclodextrin $\}$ rho

$\operatorname{dium}(\mathrm{I})$ (11): A solution of $\left[\mathrm{RhCl}(\mathrm{CO})_{2}\right]_{2}(0.024 \mathrm{~g}, 0.06 \mathrm{mmol})$ in $\mathrm{CH}_{2} \mathrm{Cl}_{2}(5 \mathrm{~mL})$ was added to a solution of TRANSDIP $(0.160 \mathrm{~g}, 0.12 \mathrm{mmol})$ in $\mathrm{CH}_{2} \mathrm{Cl}_{2}(5 \mathrm{~mL})$ under vigorous stirring. After $30 \mathrm{~min}$. the mixture was concentrated to $2 \mathrm{~mL}$ and pentane $(80 \mathrm{~mL})$ was added to precipitate unreacted starting materials, which were filtered off over a bed of Celite. Evaporation of the solvent afforded 11 as a pale yellow powder (yield $0.172 \mathrm{~g}, 97 \%$ ). $R_{\mathrm{f}}$ $\left(\mathrm{SiO}_{2}, \mathrm{CH}_{2} \mathrm{Cl}_{2} / \mathrm{MeOH}, 90: 10, \mathrm{v} / \mathrm{v}\right)=0.41 ; \mathrm{Mp} 171^{\circ} \mathrm{C}$ dec. IR $(\mathrm{KBr}) v / \mathrm{cm}^{-1}: 1982.1(\mathrm{C} \equiv \mathrm{O}) .{ }^{1} \mathrm{H}$ $\operatorname{NMR}\left(300.1 \mathrm{MHz}, \mathrm{CDCl}_{3}, 25^{\circ} \mathrm{C}\right): \delta$ (assignment by COSY) $=2.37\left(\mathrm{~m}, 2 \mathrm{H}, \mathrm{H}-6 \mathrm{a}^{\mathrm{A}, \mathrm{D} \text { or B,E}}\right)$, $2.80\left(\mathrm{~m}, 2 \mathrm{H}, \mathrm{H}-6 \mathrm{a}^{\mathrm{B}, \mathrm{E}}\right.$ or A,D $), 3.19-3.31\left(10 \mathrm{H}, \mathrm{H}-2, \mathrm{H}-4^{\mathrm{A}, \mathrm{B}, \mathrm{D}, \mathrm{E}}\right), 3.33$ (s, $\left.6 \mathrm{H}, \mathrm{OMe}\right), 3.35$ (s, 6 $\mathrm{H}, \mathrm{OMe}), 3.37$ (s, $6 \mathrm{H}, \mathrm{OMe}), 3.47$ (s, $6 \mathrm{H}, \mathrm{OMe}), 3.57$ (s, $6 \mathrm{H}, \mathrm{OMe}), 3.61$ (m, $2 \mathrm{H}, \mathrm{H}-6 \mathrm{~b}^{\mathrm{B}, \mathrm{E} \text { or }}$ A,D), $3.74(\mathrm{~s}, 6 \mathrm{H}, \mathrm{OMe}), 3.79-3.93\left(8 \mathrm{H}, \mathrm{H}-3, \mathrm{H}-6 \mathrm{~b}^{\mathrm{A}, \mathrm{D}}\right.$ or B,E $), 3.85$ (s, $\left.6 \mathrm{H}, \mathrm{OMe}\right), 4.07$ (d, $2 \mathrm{H}$, $\left.{ }^{2} J_{\mathrm{H}-6 \mathrm{a}, \mathrm{H}-6 \mathrm{~b}}=11.1 \mathrm{~Hz}, \mathrm{H}-6 \mathrm{a}^{\mathrm{C}, \mathrm{F}}\right), 4.18\left(\mathrm{~m}, 2 \mathrm{H}, \mathrm{H}-4^{\mathrm{C}, \mathrm{F}}\right), 4.80\left(\mathrm{~d}, 2 \mathrm{H},{ }^{3} J_{\mathrm{H}-1, \mathrm{H}-2}=4.3 \mathrm{~Hz}, \mathrm{H}-1^{\mathrm{A}, \mathrm{D}}\right.$ or $\mathrm{H}-1^{\mathrm{B}, \mathrm{E}}$ ), 5.00 (broad d, $\left.2 \mathrm{H},{ }^{3} J_{\mathrm{H}-5, \mathrm{H}-4}=8.8 \mathrm{~Hz}, \mathrm{H}-5^{\mathrm{C}, \mathrm{F}}\right), 5.06-5.17\left(6 \mathrm{H}, \mathrm{H}-1^{\mathrm{C}, \mathrm{F}}, \mathrm{H}-5^{\mathrm{A}, \mathrm{D}}\right.$ or B,E, $\mathrm{H}-$ $\left.6 \mathrm{~b}^{\mathrm{C}, \mathrm{F}}\right), 5.40\left(\mathrm{~d}, 2 \mathrm{H},{ }^{3} J_{\mathrm{H}-1, \mathrm{H}-2}=3.0 \mathrm{~Hz}, \mathrm{H}-1^{\mathrm{B}, \mathrm{E}}\right.$ or H-1 $\left.{ }^{\mathrm{A}, \mathrm{D}}\right), 5.68\left(\mathrm{~m}, 2 \mathrm{H}, \mathrm{H}-5^{\mathrm{B}, \mathrm{E} \text { or A,D }}\right), 6.96-7.01$ $(2 \mathrm{H}, p-\mathrm{H}), 7.08(\mathrm{~m}, 4 \mathrm{H}, m-\mathrm{H}), 7.75(\mathrm{~m}, 4 \mathrm{H}, o-\mathrm{H}) \mathrm{ppm} ;{ }^{13} \mathrm{C}\left\{{ }^{1} \mathrm{H}\right\} \mathrm{NMR}\left(75.5 \mathrm{MHz}, \mathrm{C}_{6} \mathrm{D}_{6}, 25\right.$ $\left.{ }^{\circ} \mathrm{C}\right): \delta$ (assignment by HMQC) $=32.0$ (virtual t, $\left|{ }^{1} J_{\mathrm{C}, \mathrm{P}}+{ }^{3} J_{\mathrm{C}, \mathrm{P}}{ }^{\prime}\right|=22.3$, C-6 $6^{\mathrm{A}, \mathrm{D}}$ or B,E$), 38.0$ (virtual t, $\left.\left|{ }^{1} J_{\mathrm{C}, \mathrm{P}}+{ }^{3} J_{\mathrm{C}, \mathrm{P}}\right|=18.5 \mathrm{~Hz}, \mathrm{C}-6^{\mathrm{B}, \mathrm{E} \text { or A,D }}\right), 57.3[\times 2], 58.3,59.4\left(2-\mathrm{OCH}_{3}, 6-\mathrm{OCH}_{3}\right)$, $61.5,61.8,61.9\left(3-\mathrm{OCH}_{3}\right), 66.6$ (br signal with triplet shape, $\left.\mathrm{C}-5^{\mathrm{A}, \mathrm{B} \text { or D,E}}\right), 68.5$ (br signal with triplet shape, C-5 $5^{\mathrm{B}, \mathrm{E}}$ or A,D $), 71.1\left(\mathrm{C}-5^{\mathrm{C}, \mathrm{F}}\right), 73.0\left(\mathrm{C}-6^{\mathrm{C}, \mathrm{F}}\right), 81.3,81.4$ and $83.7(\mathrm{C}-3), 81.8(\mathrm{C}-$ $\left.4^{\mathrm{C}, \mathrm{F}}\right), 82.6,82.7$ and $84.0(\mathrm{C}-2), 88.0$ (virtual t, $\left.\right|^{3} J_{\mathrm{C}, \mathrm{P}}+{ }^{5} J_{\mathrm{C}, \mathrm{P}} \mid=9.5 \mathrm{~Hz}, \mathrm{C}-4^{\mathrm{A}, \mathrm{D} \text { or B,E }}$ or C-4 $4^{\mathrm{B}, \mathrm{E} \text { or }}$ $\left.{ }^{\mathrm{A}, \mathrm{D}}\right), 90.6\left(\mathrm{C}-4^{\mathrm{B}, \mathrm{E} \text { or } \mathrm{A}, \mathrm{D}}\right.$ or C-4 $\left.4^{\mathrm{A}, \mathrm{D} \text { or B,E}}\right), 98.0\left(\mathrm{C}-1^{\mathrm{A}, \mathrm{D} \text { or B,E }}\right.$ or $\left.\mathrm{C}-1^{\mathrm{B}, \mathrm{E} \text { or A,D }}\right), 98.1\left(\mathrm{C}-1^{\mathrm{B}, \mathrm{E}}\right.$ or A,D or $\left.\mathrm{C}-1^{\mathrm{A}, \mathrm{D} \text { or B,E}}\right), 101.6\left(\mathrm{C}-1^{\mathrm{C}, \mathrm{F}}\right), 128.7$ (virtual t, $\left.\left.\right|^{3} J_{\mathrm{C}, \mathrm{P}}+{ }^{5} J_{\mathrm{C}, \mathrm{P}} \mid=8.0 \mathrm{~Hz}, m-\mathrm{C}\right), 129.3(p-\mathrm{C}), 130.4$ (virtual t, $\left|{ }^{2} J_{\mathrm{C}, \mathrm{P}}+{ }^{4} J_{\mathrm{C}, \mathrm{P}^{\mathrm{P}}}\right|=10.0 \mathrm{~Hz}, o-\mathrm{C}$ ), 140.8 (virtual t, $\left|{ }^{1} J_{\mathrm{C}, \mathrm{P}}+{ }^{3} J_{\mathrm{C}, \mathrm{P}^{\prime}}\right|=43.5 \mathrm{~Hz}$, ipso-C) 
ppm; ${ }^{31} \mathrm{P}\left\{{ }^{1} \mathrm{H}\right\}$ NMR $\left(121.5 \mathrm{MHz}, \mathrm{CDCl}_{3}, 25^{\circ} \mathrm{C}\right): \delta=-0.16\left(\mathrm{~d}, J_{\mathrm{P}, \mathrm{Rh}}=120.3 \mathrm{~Hz}\right) \mathrm{ppm}$; elemental analysis (\%): calcd for $\mathrm{C}_{63} \mathrm{H}_{94} \mathrm{ClO}_{27} \mathrm{P}_{2} \mathrm{Rh}$ (1483.71): C 51.0, H 6.39; found: $\mathrm{C}$ 50.71, H 6.40; MS (ESI-TOF): $m / z(\%): 1447.1(100)[M-\mathrm{Cl}]^{+}$.

Trans- $P, P^{\prime}$-bromo-methyl- $\left\{6^{\mathrm{A}}, 6^{\mathrm{B}}, 6^{\mathrm{D}}, 6^{\mathrm{E}}\right.$-tetradeoxy- $6^{\mathrm{A}}, 6^{\mathrm{B}}: 6^{\mathrm{D}}, 6^{\mathrm{E}}$-bis $[(R)$-phenylphosphini dene $]-2^{\mathrm{A}}, 2^{\mathrm{B}}, 2^{\mathrm{C}}, 2^{\mathrm{D}}, 2^{\mathrm{E}}, 2^{\mathrm{F}}, 3^{\mathrm{A}}, 3^{\mathrm{B}}, 3^{\mathrm{C}}, 3^{\mathrm{D}}, 3^{\mathrm{E}}, 3^{\mathrm{F}}, 6^{\mathrm{C}}, 6^{\mathrm{F}}$-tetradeca- $O$-methyl- $\alpha$-cyclodextrin $\}$ nickel(II) (12): MeLi (0.0035 g, ca. $0.10 \mathrm{~mL} 1.6 \mathrm{M}, 0.15 \mathrm{mmol})$ were added to a solution of $8(0.110 \mathrm{~g}, 0.07 \mathrm{mmol})$ in $\mathrm{Et}_{2} \mathrm{O}(10 \mathrm{~mL})$ at $-78^{\circ} \mathrm{C}$. The reaction mixture was stirred for $1 \mathrm{~h}$, before being evaporated to dryness. Toluene was added and the product filtered over a bed of Celite. Evaporation of the solvent afforded 12 as a beige solid (yield 0.060 g, 86\%). Complex 12 decomposes on silica $\left(\mathrm{SiO}_{2}\right) ; \mathrm{Mp} 148^{\circ} \mathrm{C}$ dec. ${ }^{1} \mathrm{H} \mathrm{NMR}\left(500.1 \mathrm{MHz}, \mathrm{C}_{6} \mathrm{D}_{6}, 25^{\circ} \mathrm{C}\right): \delta$ (assignment by COSY and ROESY) $=-0.94\left(\mathrm{t}, 3 \mathrm{H},{ }^{2} J_{\mathrm{H}, \mathrm{P}}=10.2 \mathrm{~Hz}, \mathrm{CH}_{3}\right), 2.20(\mathrm{~m}, 2 \mathrm{H}, \mathrm{H}-$ $6 \mathrm{a}^{\mathrm{A}, \mathrm{D} \text { or B,E }}$ ), 2.59 (m, $2 \mathrm{H}, \mathrm{H}-6 \mathrm{a}^{\mathrm{B}, \mathrm{E}}$ or A,D $), 3.15$ (virtual t, $2 \mathrm{H},{ }^{3} J_{\mathrm{H}-4, \mathrm{H}-3}={ }^{3} J_{\mathrm{H}-4, \mathrm{H}-5}=8.9 \mathrm{~Hz}, \mathrm{H}-$ $\left.4^{\mathrm{B}, \mathrm{E} \text { or A,D }}\right), 3.24-3.48\left(10 \mathrm{H}, \mathrm{H}-2, \mathrm{H}-4^{\mathrm{A}, \mathrm{B} \text { or D,E }}, \mathrm{H}-6 \mathrm{~b}^{\mathrm{B}, \mathrm{E} \text { or A,D }}\right), 3.31(\mathrm{~s}, 6 \mathrm{H}, \mathrm{OMe}), 3.37(\mathrm{~s}, 6 \mathrm{H}$, OMe), 3.39 (s, $6 \mathrm{H}, \mathrm{OMe}), 3.40$ (s, $6 \mathrm{H}, \mathrm{OMe}), 3.57$ (m, $\left.2 \mathrm{H}, \mathrm{H}-6 \mathrm{~b}^{\mathrm{A}, \mathrm{D} \text { or B,E }}\right), 3.64-4.02(8 \mathrm{H}$, $\mathrm{H}-3, \mathrm{H}-6 \mathrm{a}^{\mathrm{C}, \mathrm{F}}$ ), 3.71 (s, $\left.6 \mathrm{H}, \mathrm{OMe}\right), 3.74(\mathrm{~s}, 6 \mathrm{H}, \mathrm{OMe}), 3.76$ (s, $\left.6 \mathrm{H}, \mathrm{OMe}\right), 3.78$ (virtual triplet, $\left.2 \mathrm{H},{ }^{3} J_{\mathrm{H}-4, \mathrm{H}-3}={ }^{3} J_{\mathrm{H}-4, \mathrm{H}-5}=9.0 \mathrm{~Hz}, \mathrm{H}-4{ }^{\mathrm{C}, \mathrm{F}}\right), 4.75\left(\mathrm{~d}, 2 \mathrm{H},{ }^{3} J_{\mathrm{H}-1, \mathrm{H}-2}=4.0 \mathrm{~Hz}, \mathrm{H}-1^{\mathrm{A}, \mathrm{D} \text { or B,E}}\right)$, $5.00\left(\mathrm{~m}, 2 \mathrm{H}, \mathrm{H}-6 \mathrm{~b}^{\mathrm{C}, \mathrm{F}}\right), 5.15\left(\mathrm{~m}, 2 \mathrm{H}, \mathrm{H}-5^{\mathrm{A}, \mathrm{D}}\right.$ or B,E$), 5,19\left(\mathrm{~d}, 2 \mathrm{H},{ }^{3} J_{\mathrm{H}-1, \mathrm{H}-2}=3.7 \mathrm{~Hz}, \mathrm{H}-1^{\mathrm{C}, \mathrm{F}}\right)$, $5.24\left(\mathrm{~m}, 2 \mathrm{H}, \mathrm{H}-5^{\mathrm{C}, \mathrm{F}}\right), 5.41\left(\mathrm{~d}, 2 \mathrm{H},{ }^{3} J_{\mathrm{H}-1, \mathrm{H}-2}=3.0 \mathrm{~Hz}, \mathrm{H}-1^{\mathrm{B}, \mathrm{E} \text { or A,D }}\right), 5.93\left(\mathrm{~m}, 2 \mathrm{H}, \mathrm{H}-5^{\mathrm{B}, \mathrm{E} \text { or A,D}}\right)$, 7.03 (broad t, $\left.2 \mathrm{H},{ }^{3} J_{p-\mathrm{H}, m-\mathrm{H}}=7.4 \mathrm{~Hz}, p-\mathrm{H}\right), 7.13\left(\right.$ broad t, $\left.4 \mathrm{H},{ }^{3} J_{m-\mathrm{H}, p-\mathrm{H}}=7.4 \mathrm{~Hz}, m-\mathrm{H}\right), 7.79$ (m, $4 \mathrm{H}, o-\mathrm{H}) \mathrm{ppm} ;{ }^{13} \mathrm{C}\left\{{ }^{1} \mathrm{H}\right\} \mathrm{NMR}\left(75.5 \mathrm{MHz}, \mathrm{C}_{6} \mathrm{D}_{6}, 25{ }^{\circ} \mathrm{C}\right): \delta$ (assignment by HMQC) $=-$ $2.1\left(\mathrm{~m}, \mathrm{CH}_{3}\right), 29.3\left(\mathrm{~m}, \mathrm{C}-6^{\mathrm{A}, \mathrm{D} \text { or B,E}}\right), 35.7\left(\mathrm{C}-6^{\mathrm{B}, \mathrm{E} \text { or A,D }}\right), 57.0,57.1,57.7,57.8,59.0,69.4,61.6$ $\left(2-\mathrm{OCH}_{3}, 3-\mathrm{OCH}_{3}, 6-\mathrm{OCH}_{3}\right), 66.4$ ( $\mathrm{m}$ with triplet shape, C-5 ${ }^{\mathrm{A}, \mathrm{D}}$ or B,E $), 68.7$ (m with triplet shape, C-5 ${ }^{\mathrm{B}, \mathrm{E}}$ or A,D $), 71.8\left(\mathrm{C}-5^{\mathrm{C}, \mathrm{F}}\right), 72.8\left(\mathrm{C}-6^{\mathrm{C}, \mathrm{F}}\right), 71.6,81.7,81.8,82.6,82.7,83.8,84.3,86.9$, $90.5(\mathrm{C}-2, \mathrm{C}-3, \mathrm{C}-4), 97.6\left(\mathrm{C}-1^{\mathrm{B}, \mathrm{E}}\right.$ or A,D $), 97.8\left(\mathrm{C}-1^{\mathrm{A}, \mathrm{D}}\right.$ or B,E $), 101.6\left(\mathrm{C}-1^{\mathrm{C}, \mathrm{F}}\right)$, aromatic $\mathrm{CH}$ signals overlap with $\mathrm{C}_{6} \mathrm{D}_{6}$ signal, 138.4 (ipso-C) ppm; ${ }^{31} \mathrm{P}\left\{{ }^{1} \mathrm{H}\right\}$ NMR (121.5 MHz, $\mathrm{C}_{6} \mathrm{D}_{6}$, $25^{\circ} \mathrm{C}$ ): $\delta=0.5$ (s) ppm; elemental analysis (\%): calcd for $\mathrm{C}_{63} \mathrm{H}_{97} \mathrm{BrO}_{26} \mathrm{P}_{2} \mathrm{Ni} \cdot 3\left(\mathrm{CH}_{2} \mathrm{Cl}_{2}\right)$ $(1470.97+254.79)$ : C 45.93, H 6.02; found: C 45.61, H 6.29. Attempts to detect complex 12 by mass spectrometry were unsucessful.

$P, P^{\prime}-\left\{6^{\mathrm{A}}, 6^{\mathrm{B}}, 6^{\mathrm{D}}, 6^{\mathrm{E}}-\right.$ Tetradeoxy- $6^{\mathrm{A}}, 6^{\mathrm{B}}: 6^{\mathrm{D}}, 6^{\mathrm{E}}-$ bis $[(R)$-phenylphosphinidene $]-2^{\mathrm{A}}, 2^{\mathrm{B}}, 2^{\mathrm{C}}, 2^{\mathrm{D}}, 2^{\mathrm{E}}$, $2^{\mathrm{F}}, 3^{\mathrm{A}}, 3^{\mathrm{B}}, 3^{\mathrm{C}}, 3^{\mathrm{D}}, 3^{\mathrm{E}}, 3^{\mathrm{F}}, 6^{\mathrm{C}}, 6^{\mathrm{F}}$-tetradeca- $O$-methyl- $\alpha$-cyclodextrin $\}$ gold(I) hexafluorophos phate (13): To a stirred solution of TRANSDIP $(0.160 \mathrm{~g}, 0.12 \mathrm{mmol})$ in $\mathrm{CH}_{2} \mathrm{Cl}_{2}(10 \mathrm{~mL})$ was added a solution of $[\mathrm{AuCl}(\mathrm{THT})](0.040 \mathrm{~g}, 0.12 \mathrm{mmol})$ in $\mathrm{CH}_{2} \mathrm{Cl}_{2}(10 \mathrm{~mL})$. After $0.5 \mathrm{~h}$ 
the solution was added to a suspension of thallium hexafluorophosphate $(0.044 \mathrm{~g}, 0.12 \mathrm{mmol})$ in acetonitrile $(2 \mathrm{~mL})$. After stirring for $5 \mathrm{~min}$., the white precipitate was filtered through a bed of Celite and the filtered solution was concentrated to $c a .5 \mathrm{~mL}$. Addition of pentane yielded complex 13 as a colourless precipitate (yield $0.180 \mathrm{~g}, 91 \%) . R_{\mathrm{f}}\left(\mathrm{SiO}_{2}, \mathrm{CH}_{2} \mathrm{Cl}_{2} / \mathrm{MeOH}\right.$, 90:10, v/v) $=0.31 ; \mathrm{Mp}>250^{\circ} \mathrm{C} .{ }^{1} \mathrm{H}$ NMR $\left(300.1 \mathrm{MHz}, \mathrm{CDCl}_{3}, 25^{\circ} \mathrm{C}\right): \delta$ (assignment by $\operatorname{COSY})=2.18\left(\mathrm{~m}, 2 \mathrm{H}, \mathrm{H}-6 \mathrm{a}^{\mathrm{A}, \mathrm{D} \text { or B,E }}\right), 2.62\left(\mathrm{~m}, 2 \mathrm{H}, \mathrm{H}-6 \mathrm{a}^{\mathrm{B}, \mathrm{E}}\right.$ or A,D $), 2.79$ (s, $\left.6 \mathrm{H}, \mathrm{OMe}\right), 3.07-$ 3.73 (24 H, H-2, H-3, H-4, H-6b ${ }^{\mathrm{A}, \mathrm{B}, \mathrm{D}, \mathrm{E}}, \mathrm{H}-6 \mathrm{a}^{\mathrm{C}, \mathrm{F}}$ ), 3.47 (s, $6 \mathrm{H}, \mathrm{OMe}$ ), 3.53 (s, $\left.6 \mathrm{H}, \mathrm{OMe}\right), 3.57$ (s, $6 \mathrm{H}, \mathrm{OMe}), 3.63$ (s, $6 \mathrm{H}, \mathrm{OMe}), 3.65$ (s, $6 \mathrm{H}, \mathrm{OMe}), 3.66$ (s, $6 \mathrm{H}, \mathrm{OMe}), 3.89$ (m, $2 \mathrm{H}, \mathrm{H}-$ $\left.5^{\mathrm{C}, \mathrm{F}}\right), 4.16\left(\mathrm{~m}, 2 \mathrm{H}, \mathrm{H}-6 \mathrm{~b}^{\mathrm{C}, \mathrm{F}}\right), 4.24\left(\mathrm{~m}, 2 \mathrm{H}, \mathrm{H}-5^{\mathrm{B}, \mathrm{E} \text { or A,D }}\right), 4.36\left(\mathrm{~m}, 2 \mathrm{H}, \mathrm{H}-5^{\mathrm{A}, \mathrm{D} \text { or B,E}}\right), 4.83(\mathrm{~d}, 2$ $\mathrm{H},{ }^{3} J_{\mathrm{H}-1, \mathrm{H}-2}=3.2 \mathrm{~Hz}, \mathrm{H}-1^{\mathrm{A}, \mathrm{D}}$ or B,E$), 5.05$ (two overlapping d, $4 \mathrm{H}, \mathrm{H}-1^{\mathrm{B}, \mathrm{E}}$ or A,D, $\mathrm{H}-1^{\mathrm{C}, \mathrm{F}}$ ), $7.41-$ $7.61\left(10 \mathrm{H}\right.$, aromatic H) ppm; ${ }^{13} \mathrm{C}\left\{{ }^{1} \mathrm{H}\right\}$ NMR $\left(75.5 \mathrm{MHz}, \mathrm{CDCl}_{3}, 25{ }^{\circ} \mathrm{C}\right): \delta$ (assignment by $\mathrm{HMQC})=27.9\left(\mathrm{~m}, \mathrm{C}-6^{\mathrm{B}, \mathrm{E}}\right.$ or A,D $), 37.2\left(\mathrm{~m}, \mathrm{C}-6^{\mathrm{A}, \mathrm{D} \text { or B,E}}\right), 57.8,58.0,58.2\left(2-\mathrm{OCH}_{3}\right), 59.8(6-$ $\left.\mathrm{OCH}_{3}\right), 61.5,61.6,62.0\left(3-\mathrm{OCH}_{3}\right), 64.2\left(\mathrm{C}-5^{\mathrm{B}, \mathrm{E}}\right.$ or A,D $), 71.7\left(\mathrm{~m}, \mathrm{C}-5^{\mathrm{A}, \mathrm{D} \text { or B,E}}\right), 72.9\left(\mathrm{C}-5^{\mathrm{C}, \mathrm{F}}\right)$, $73.5\left(\mathrm{C}-6^{\mathrm{C}, \mathrm{F}}\right), 80.6,80.9$ [×2], 81.1, 81.3, 82.6, $83.9\left(\mathrm{C}-2, \mathrm{C}-3, \mathrm{C}-4^{\mathrm{C}, \mathrm{F}}\right), 86.1\left(\mathrm{~m}, \mathrm{C}-4^{\mathrm{B}, \mathrm{E}}\right.$ or A,D $)$, $88.3\left(\mathrm{C}-4^{\mathrm{A}, \mathrm{D} \text { or B,E}}\right), 98.8\left(\mathrm{C}-1^{\mathrm{B}, \mathrm{E} \text { or A,D }}\right), 99.5\left(\mathrm{C}-1^{\mathrm{A}, \mathrm{D} \text { or B,E}}\right), 100.4\left(\mathrm{C}-1^{\mathrm{C}, \mathrm{F}}\right), 129.7$ (virtual t, $\left.\right|^{3} J_{\mathrm{C}, \mathrm{P}}$ $\left.+{ }^{5} J_{\mathrm{C}, \mathrm{P}}{ }^{\prime} \mid=11.2 \mathrm{~Hz}, m-\mathrm{C}\right), 132.2$ (virtual t, $\left|{ }^{2} J_{\mathrm{C}, \mathrm{P}}+{ }^{4} J_{\mathrm{C}, \mathrm{P}}\right|=13.0 \mathrm{~Hz}, o-\mathrm{C}$ ); 132.6 (p-C) ppm; ${ }^{19} \mathrm{~F}\left\{{ }^{1} \mathrm{H}\right\} \mathrm{NMR}\left(282.4 \mathrm{MHz}, \mathrm{CDCl}_{3}, 25^{\circ} \mathrm{C}\right): \delta=-72.8\left(\mathrm{~d},{ }^{1} J_{\mathrm{F}, \mathrm{P}}=716 \mathrm{~Hz}\right) \mathrm{ppm} ;{ }^{31} \mathrm{P}\left\{{ }^{1} \mathrm{H}\right\} \mathrm{NMR}$ $\left(121.5 \mathrm{MHz}, \mathrm{CDCl}_{3}, 25^{\circ} \mathrm{C}\right): \delta=38.6(\mathrm{~s}),-144.3\left(\mathrm{~h},{ }^{1} J_{\mathrm{P}, \mathrm{F}}=716 \mathrm{~Hz}\right) \mathrm{ppm}$; elemental analysis (\%): calcd for $\mathrm{C}_{62} \mathrm{H}_{94} \mathrm{AuF}_{6} \mathrm{O}_{26} \mathrm{P}_{3}$ (1659.27): C 44.88, H 5.71; found: C 44.71, H 5.83; MS (ESI-TOF): $m / z(\%): 1513.1(100)\left[M-\mathrm{PF}_{6}\right]^{+}$.

X-ray crystallographic data of 6: $2 \mathrm{PdP}_{2} \mathrm{C}_{62} \mathrm{H}_{94} \mathrm{Cl}_{2} \mathrm{O}_{26} \cdot 2 \mathrm{C}_{5} \mathrm{H}_{12}, M \mathrm{r}=3275.32$, triclinic, $P 1, a$ $=14.419(5), b=14.913(5), c=19.382(5) \AA, \alpha=79.985(7), \beta=79.750(8), \gamma=87.252(8)^{\circ}, V$ $=4038(1) \AA^{3}, Z=1, D_{\mathrm{X}}=1.347 \mathrm{Mg} \cdot \mathrm{m}^{-3}, \lambda(\mathrm{MoK} \alpha)=0.71073 \AA, \mu=4.82 \mathrm{~cm}^{-1}, F(000)=$ $1720, T=110(1) \mathrm{K}$. Single crystals were obtained by slow diffusion of pentane into a chloroform solution of 6. A sample was studied on an Oxford Diffraction Xcalibur Saphir 3 diffractometer with graphite monochromatised $\operatorname{MoK} \alpha$ radiation $(\lambda=0.71069 \AA)$. The data collection $^{[52]}\left(2 \theta_{\max }=54^{\circ}, \omega\right.$ scan frames via $0.7^{\circ} \omega$ rotation and $20 \mathrm{~s}$ per frame, range HKL: H -8-21; K -21-21; L -27-27) gave 28266 reflections. The data led to 20976 independent reflections from which 9809 had $I>2.0 \sigma(I)$. The structure was solved with SIR-97, ${ }^{[53]}$ which revealed the non-hydrogen atoms of the molecule. After anisotropic refinement, the hydrogen atoms were located by use of a Fourier Difference. The whole structure was refined with SHELXL-97 ${ }^{[54]}$ by the full-matrix least-square techniques (use of $F^{2}$ magnitude; x, y, z, $\beta_{\mathrm{ij}}$ for $\mathrm{C}, \mathrm{Cl}, \mathrm{O}, \mathrm{P}$ and $\mathrm{Pd}$ atoms, $\mathrm{x}, \mathrm{y}, \mathrm{z}$ in riding mode for $\mathrm{H}$ atoms; 1685 variables and 9809 
observations with $I>2.0 \sigma(I)$; calc. $w=1 /\left[\sigma^{2}\left(F_{\mathrm{o}}{ }^{2}\right)+(0.03 P)^{2}\right]$ where $P=\left(F_{\mathrm{o}}{ }^{2}+2 F_{\mathrm{c}}{ }^{2}\right) / 3$ with the resulting $R=0.125, R_{\mathrm{w}}=0.314$ and $S_{\mathrm{w}}=1.096, \Delta \rho<3.5 \mathrm{e}^{-3}$. Flack's parameter: $0.03(5)$. The unit cell contains two slightly different molecules and two molecules of pentane. Owing to crystals of medium quality (probably arising from the presence of the solvent molecules), and as frequently observed in cyclodextrin structures, the refinement did not fully converge.

X-ray crystallographic data of 13: $\mathrm{AuP}_{2} \mathrm{C}_{62} \mathrm{H}_{94} \mathrm{~F}_{6} \mathrm{O}_{26} \mathrm{P} \bullet 4 \mathrm{C}_{2} \mathrm{Cl}_{4} \mathrm{H}_{2}, M \mathrm{r}=2330.59$, triclinic, $P 1, a=13.8155(6), b=14.3165(6), c=15.1126(7) \AA, \alpha=112.842(4), \beta=110.568(4), \gamma=$ 100.381(3) $, V=2399.2(2) \AA^{3}, Z=1, D_{\mathrm{X}}=1.209 \mathrm{Mg} \cdot \mathrm{m}^{-3}, \lambda(\mathrm{MoK} \alpha)=0.71073 \AA, \mu=21.09$ $\mathrm{cm}^{-1}, \mathrm{~F}(000)=1180, \mathrm{~T}=100(1) \mathrm{K}$. Single crystals were obtained by cooling a solution of the complex in $\mathrm{C}_{2} \mathrm{Cl}_{4} \mathrm{H}_{2}$. A sample was studied on a Bruker AXS X8-APEX II with graphite monochromatized MoK $\alpha$ radiation. The data collection ${ }^{[55]}\left(2 \theta_{\max }=54^{\circ}\right.$, distance detector $=$ $60 \mathrm{~mm}, \phi$ scan frames via $0.7^{\circ} \phi$ rotation and $20 \mathrm{~s}$ per frame, range HKL : H -19,16 K -19,20 L -21,21) gave 23078 reflections. The data led to 16677 independent reflections from which 14250 with $I>2.0 \sigma(I)$. The structure was solved with SIR-97, ${ }^{[53]}$ which revealed the non hydrogen atoms of the molecule. After anisotropic refinement, many hydrogen atoms may be found with a Fourier Difference. The whole structure was refined with SHELXL97 ${ }^{[54]}$ by the full-matrix least-square techniques (use of F square magnitude; $x, y, z, \beta_{i j}$ for $\mathrm{Au}, \mathrm{P}, \mathrm{Cl}, \mathrm{C}$ and $\mathrm{O}$ atoms, $\mathrm{x}, \mathrm{y}, \mathrm{z}$ in riding mode for $\mathrm{H}$ atoms; 1100 variables and 14250 observations with $I>2.0 \sigma(I)$; calc $w=1 /\left[\sigma^{2}\left(F_{\mathrm{O}}^{2}\right)+(0.172 P)^{2}\right]$ where $P=\left(F_{\mathrm{O}}^{2}+2 F_{\mathrm{c}}^{2}\right) / 3$ with the resulting $R$ $=0.068, R_{\mathrm{W}}=0.179$ and $S_{\mathrm{W}}=0.882, \Delta \rho<6.1 \AA^{-3}$. Flack's parameter: 0.03 (5). The molecule cristallises with four solvent molecules, one of which lies inside the CD. CCDC reference numbers 648501 (6) and 631157 (13) contain the supplementary crystallographic data for this paper. These data can be obtained free of charge from The Cambridge Crystallographic Data Centre via www.ccdc.cam.ac.uk/data request/cif.

General procedures for olefin dimerisation: $\left[\mathrm{NiBr}_{2}\right]$ and $\left[\mathrm{NiBr}_{2}(\mathrm{DME})\right]$ were purchased from Aldrich and used without further purification. Methylaluminoxane (MAO) $10 \mathrm{wt} \%$ (Aldrich) was used as a white powder which was obtained after evaporation of the solvent $\left(60^{\circ} \mathrm{C}, 3 \mathrm{~h}\right)$. This treatment reduces the amount of residual trimethylaluminium to $c a .3 \%$. The resulting solid residue was dried during $3 \mathrm{~h}$ at $60^{\circ} \mathrm{C}$ under vacuum. All $\mathrm{Ni}$ complexes and MAO were weighed in a dry box (dry argon); the autoclave was charged under a slight flow of ethene or propene. Toluene and chlorobenzene were dried by conventional methods and distilled immediately prior to use. Gas chromatographic (GC) analysis were performed on a 
VARIAN 3900 gas chromatograph using a WCOT Fused Silica Column (25 m, 0.32 mm intern diameter, $0.25 \mathrm{~mm}$ film thickness).

Ethene dimerisation: A $100 \mathrm{~mL}$ steel autoclave was heated at $100^{\circ} \mathrm{C}$ under vacuum for $2 \mathrm{~h}$, cooled to room temperature and filled with ethene. The catalyst $(4.50 \mu \mathrm{mol})$ was dissolved in toluene $(12 \mathrm{~mL})$ before being introduced into the autoclave via a syringe under low ethene pressure. The solution was stirred for $15 \mathrm{~min}$. whereupon the reactor was vented before a solution of MAO [400 equiv. (0.090 g, ca. $1.80 \mathrm{mmol})$ to 2000 equiv. (0.450 g, ca. 9.00 $\mathrm{mmol})]$ in toluene $(10 \mathrm{~mL})$ was added. The reactor was pressurised at $25^{\circ} \mathrm{C}$ and stirred for the desired reaction time. At the end of the run, the autoclave was cooled down to $7^{\circ} \mathrm{C}$, then depressurised over $1 \mathrm{~h}$. The flask containing the reaction mixture was immediately after weighed in order to limit loss of butane products. The yield was determined by mass comparison of the reaction mixture with a control solution $(22 \mathrm{~mL}$ of toluene stirred for 30 min. at $25^{\circ} \mathrm{C}$ under ethene pressure; depressurisation was carried out as for the reaction mixture). ${ }^{[56]}$ The mass of MAO used for catalysis was taken into account in the final yield determination. The products were analysed by ${ }^{1} \mathrm{H}$ NMR spectroscopy and GC. ${ }^{[56]}$ But-1-ene was identified by ${ }^{1} \mathrm{H}$ NMR resonances at $\delta 2.00,4.95$ and $5.78 \mathrm{ppm}$. Resonances for the cis and trans isomers of but-2-ene appear at $\delta 1.54$ and $4.95 \mathrm{ppm}$, respectively $\delta 1.58$ and 5.55 ppm.

Propene dimerisation: A $200 \mathrm{~mL}$ Büchi glass autoclave was heated at $100^{\circ} \mathrm{C}$ under vacuum for $2 \mathrm{~h}$, then cooled to room temperature and filled with propene. A solution of $8(0.007 \mathrm{~g}$, $4.50 \mu \mathrm{mol})$ in chlorobenzene $(20 \mathrm{~mL})$ was introduced into the autoclave via a syringe under a low propene flow. The solution was stirred for $15 \mathrm{~min}$. whereupon the reactor was vented before a solution of MAO (2000 equiv., $0.450 \mathrm{~g}, c a .9 .00 \mathrm{mmol})$ in chlorobenzene $(10 \mathrm{~mL})$ was added. The reactor was pressurised at $25^{\circ} \mathrm{C}$ and stirred for $1 \mathrm{~h}$. At the end of the run, the autoclave was cooled down to $5^{\circ} \mathrm{C}$, then depressurised over $1 \mathrm{~h}$. The yield was determined as for the dimerisation of ethene. Finally, heptane $(1 \mathrm{~mL})$ was added as internal standard and a sample of the reaction mixture was taken for GC analysis.

\section{Acknowledgment}

This work was supported by the Agence Nationale de la Recherche. The French ministère de l'éducation nationale is gratefully acknowledged for a grant to L.P. 
[1] A. Werner, Z. Anorg. Chem. 1893, 3, 267-330.

[2] A. Werner, Ber. 1907, 40, 15-69.

[3] P. Pfeiffer, M. Haimann, Ber. 1903, 36, 1063-1069.

[4] L. Tschugaeff, Ber. 1906, 39, 3190-3201.

[5] N. Schlesinger, Ber. 1925, 58, 1877-1889.

[6] H. D. K. Drew, H. J. Tress, J. Chem. Soc. 1933, 1335-1341.

[7] P. Pfeiffer, E. Lübbe, J. Prakt. Chem. 1933, 136, 321-328.

[8] H. J. Tress, J. Soc. Chem. Ind., London 1938, 57, 1234-1235.

[9] S. Otsuka, J. Organomet. Chem. 1980, 200, 191-205.

[10] K. Issleib, G. Hohlfeld, Z. Anorg. Allg. Chem. 1961, 312, 169-179.

[11] D. M. A. Minahan, W. E. Hill, C. A. McAuliffe, Coord. Chem. Rev. 1984, 55, 31-54.

[12] I. Mochida, J. A. Mattern, J. C. Bailar Jr., J. Am. Chem. Soc. 1975, 97, 3021-3026.

[13] J. A. Mattern, Thesis 1946, University of Illinois.

[14] N. J. DeStefano, D. K. Jonhnson, L. M. Venanzi, Angew. Chem. Int. Ed. 1974, 13, 133-134.

[15] N. J. DeStefano, D. K. Johnson, R. M. Lane, L. M. Venanzi, Helv. Chim. Acta 1976, 59, 2674-2682.

[16] F. Bachechi, L. Zambonelli, L. M. Venanzi, Helv. Chim. Acta 1977, 60, 2815-2823.

[17] M. Sawamura, H. Hamashima, Y. Ito, Tetrahedron: Asymm. 1991, 2, 593-596.

[18] M. Sawamura, H. Hamashima, M. Sugawara, R. Kuwano, Y. Ito, Organometallics 1995, 14, 4549-4558.

[19] P. C. J. Kamer, M. Kranenburg, P. W. N. M. van Leeuwen, in Book of Abstracts, XVIth International Conference Organometallic Chemistry, The Royal Society of Chemistry - Dalton Divison, University of Sussex.

[20] S. Hillebrand, J. Bruckmann, C. Krüger, M. W. Haenel, Tetrahedron Lett. 1995, 36, $75-78$.

[21] J. Yin, S. L. Buchwald, J. Am. Chem. Soc. 2002, 124, 6043-6048.

[22] Z. Freixa, M. S. Beentjes, G. D. Batema, C. B. Dieleman, G. P. F. van Strijdonck, J. N. H. Reek, P. C. J. Kamer, J. Fraanje, K. Goubitz, P. W. N. M. van Leeuwen, Angew. Chem. Int. Ed. 2003, 42, 1284-1287.

[23] R. C. Smith, J. D. Protasiewicz, Organometallics 2004, 23, 4215-4222.

[24] O. Grossman, C. Azerraf, D. Gelman, Organometallics 2006, 25, 375-381.

[25] C. Azerraf, O. Grossman, D. Gelman, J. Organometal. Chem. 2007, 692, 761-767.

[26] L. A. van der Veen, P. H. Keeven, G. C. Schoemaker, J. N. H. Reek, P. C. J. Kamer, P. W. N. M. van Leeuwen, M. Lutz, A. L. Spek, Organometallics 2000, 19, 872-883.

[27] G. Petöcz, Z. Berente, T. Kégl, L. Kollár, J. Organomet. Chem. 2004, 689, 1188-1193.

[28] M. L. Parr, C. Perez-Acosta, J. W. Faller, New J. Chem. 2005, 29, 613-619.

[29] G. Bracher, D. M. Grove, L. M. Venanzi, F. Bachechi, P. Mura, L. Zambonelli, Helv. Chim. Acta 1980, 63, 2519-2530.

[30] C. Jiménez-Rodríguez, F. X. Roca, C. Bo, J. Benet-Buchholz, E. C. Escudero-Adán, Z. Freixa, P. W. N. M. van Leeuwen, Dalton Trans. 2006, 268-278.

[31] C. Wieser-Jeunesse, D. Matt, A. De Cian, Angew. Chem. Int. Ed. 1998, 37, 28612864.

[32] M. Lejeune, C. Jeunesse, D. Matt, N. Kyritsakas, R. Welter, J.-P. Kintzinger, J. Chem. Soc., Dalton Trans. 2002, 1642-1650.

[33] E. Engeldinger, D. Armspach, D. Matt, Angew. Chem. Int. Ed. 2001, 40, 2526-2529. 
[34] E. Engeldinger, D. Armspach, D. Matt, P. G. Jones, Chem. Eur. J. 2003, 9, 30913105.

[35] E. Engeldinger, L. Poorters, D. Armspach, D. Matt, L. Toupet, Chem. Comm. 2004, 634-635.

[36] P. S. Pregosin, R. W. Kunz, ${ }^{31} P$ and ${ }^{13} C$ NMR of Transition Metal Phosphine Complexes, Eds., P. Drehl, E. Fluck, R. Kosfeld, Springer, Berlin, 1979.

[37] C. A. Bessel, P. Aggarwal, A. C. Marschilok, K. J. Takeuchi, Chem. Rev. 2001, 101, 1031-1066.

[38] E. Engeldinger, D. Armspach, D. Matt, P. G. Jones, R. Welter, Angew. Chem. Int. Ed. 2002, 41, 2593-2596.

[39] H. F. Klein, H. H. Karsch, Chem. Ber. 1972, 105, 2628-2636.

[40] M. C. Blanco, E. J. Fernández, P. G. Jones, A. Laguna, J. M. López-de-Luzuriaga, M. E. Olmos, Angew. Chem., Int. Ed. 1998, 37, 3042-3043.

[41] A. Bauer, H. Schmidbaur, J. Am. Chem. Soc. 1996, 118, 5324-5325.

[42] J. A. Muir, M. M. Muir, L. B. Pulgar, P. G. Jones, G. M. Sheldrick, Acta Cryst. B41, 1174-1176 1985, 41, 1174-1176.

[43] L. Poorters, D. Armspach, D. Matt, L. Toupet, P. G. Jones, Angew. Chem. Int. Ed. 2007, 46, 2663-2665.

[44] M. Lejeune, D. Sémeril, C. Jeunesse, D. Matt, F. Peruch, P. J. Lutz, L. Ricard, Chem. Eur. J. 2004, 10, 5354-5360.

[45] M. Lejeune, D. Sémeril, C. Jeunesse, D. Matt, P. J. Lutz, L. Toupet, Adv. Synth. Catal. 2006, 348, 881-886.

[46] S. Muthukumaru Pillai, M. Ravindranathan, S. Sivaram, Chem. Rev. 1986, 86, 353399.

[47] A. Yamamoto, J. Chem. Soc., Dalton Trans. 1999, 1027-1037.

[48] A. M. Echavarren, D. J. Cárdenas, in Metal-Catalyzed Cross-Coupling Reactions Vol.1 (Eds: A. de Meijere, F. Diederich), Wiley-VCH, Weinheim, 2004, pp. 1-40.

[49] F. R. Hartley, The Chemistry of Platinum and Palladium, Wiley, New York, 1973.

[50] R. E. Rülke, J. M. Ernsting, A. L. Spek, C. J. Elsevier, P. W. N. M. van Leeuwen, K. Vrieze, Inorg. Chem. 1993, 32, 5769-5778.

[51] R. Uson, A. Laguna, M. Laguna, Inorg. Synthesis 1989, 26, 85-87.

[52] O. D. L. CrysAlis RED software, version 1.171.29.9.

[53] A. Altomare, M. C. Burla, M. Camalli, G. Cascarano, C. Giacovazzo, A. Guagliardi, A. G. G. Moliterni, G. Polidori, R. Spagna, J. Appl. Cryst. 1998, 31, 74-77.

[54] G. M. Sheldrick, SHELX-97. Program for the Refinement of Crystal Structures, University of Göttingen, Germany, 1997.

[55] SMART software (version 5.611) and SAINT+ (version 6.45). Bruker AXS inc., Madison, Wisconsin, USA.

[56] J. M. Malinoski, M. Brookhart, Organometallics 2003, 22, 5324-5335. 


\author{
Chem. Eur. J.
}

\title{
Supporting information
}

\section{Synthesis and properties of TRANSDIP, a rigid chelator built upon a cyclodextrin cavity. Is TRANSDIP an authentic trans-spanning ligand?}

Laurent Poorters, ${ }^{[a]}$ Dominique Armspach, ${ }^{*}[\mathrm{a}]$ Dominique Matt, ${ }^{*[a]}$ Loïc Toupet, ${ }^{[b]}$ Sylvie Choua, ${ }^{[\mathrm{cl}]}$ Philippe Turek ${ }^{[\mathrm{cl}]}$

[a] Dr. L. Poorters, Dr. D. Armspach, Dr. D. Matt, Laboratoire de Chimie Inorganique Moléculaire Université Louis Pasteur, Institut de Chimie UMR 7177 CNRS 1 rue Blaise Pascal, F-67008 Strasbourg Cedex France.

E-mail:dmatt@chimie.u-strasbg.fr

[b] Dr. L. Toupet Université de Rennes 1

Groupe matière condensée et matériaux UMR 6626

Campus de Beaulieu, F-35042, Rennes Cedex, France

[c] Dr. S. Choua, Prof. P. Turek Laboratoire de RPE

Université Louis Pasteur, Institut de Chimie UMR 7177 CNRS 1 rue Blaise Pascal, F-67008 Strasbourg Cedex France 


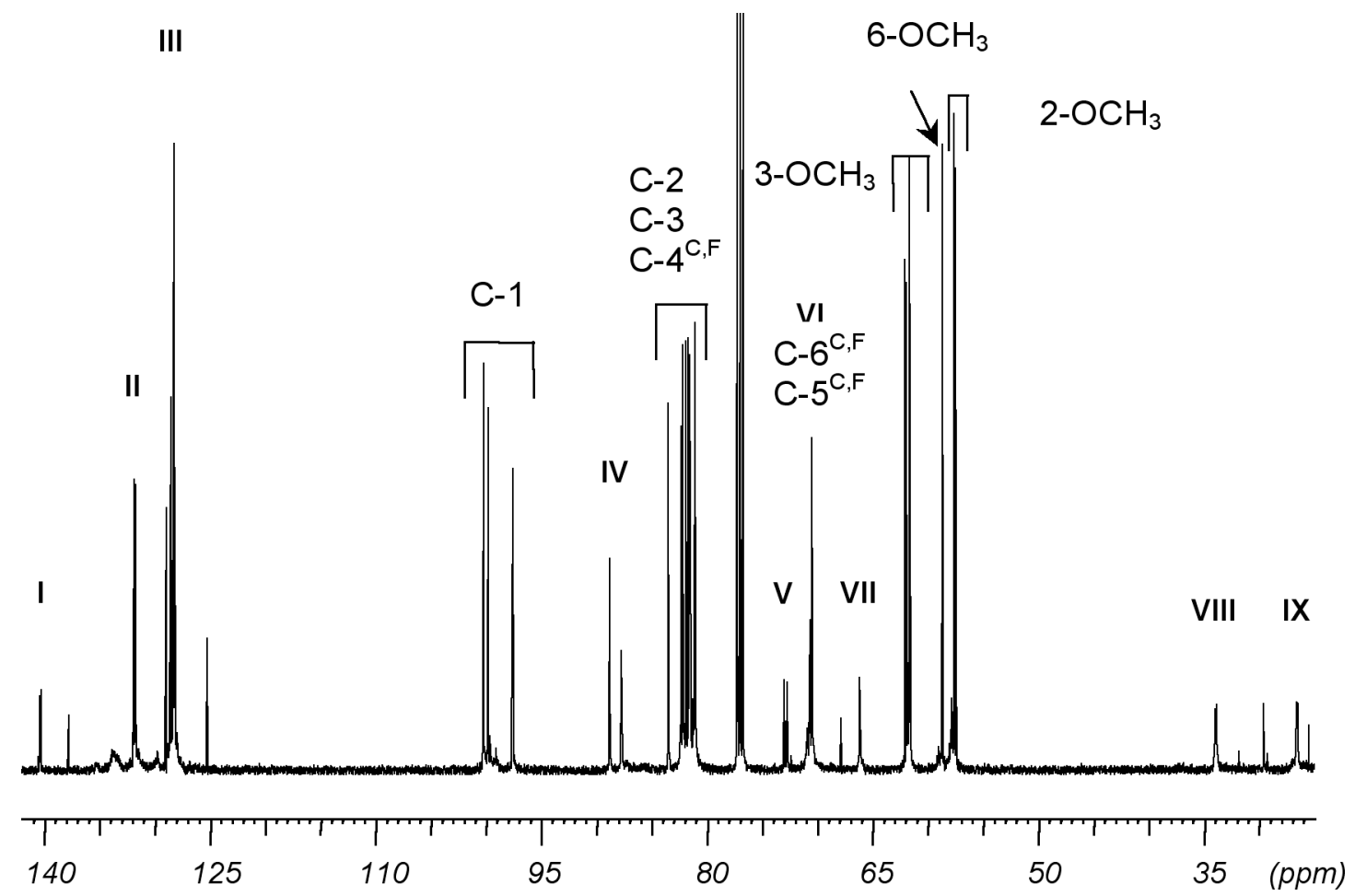

Figure SI1. ${ }^{13} \mathrm{C}\left\{{ }^{1} \mathrm{H}\right\}$ NMR spectrum of TRANSDIP recorded in $\mathrm{CDCl}_{3}$ at $125.8 \mathrm{MHz}$. Enlargements of the regions I-IX are found in Fig. SI2. 

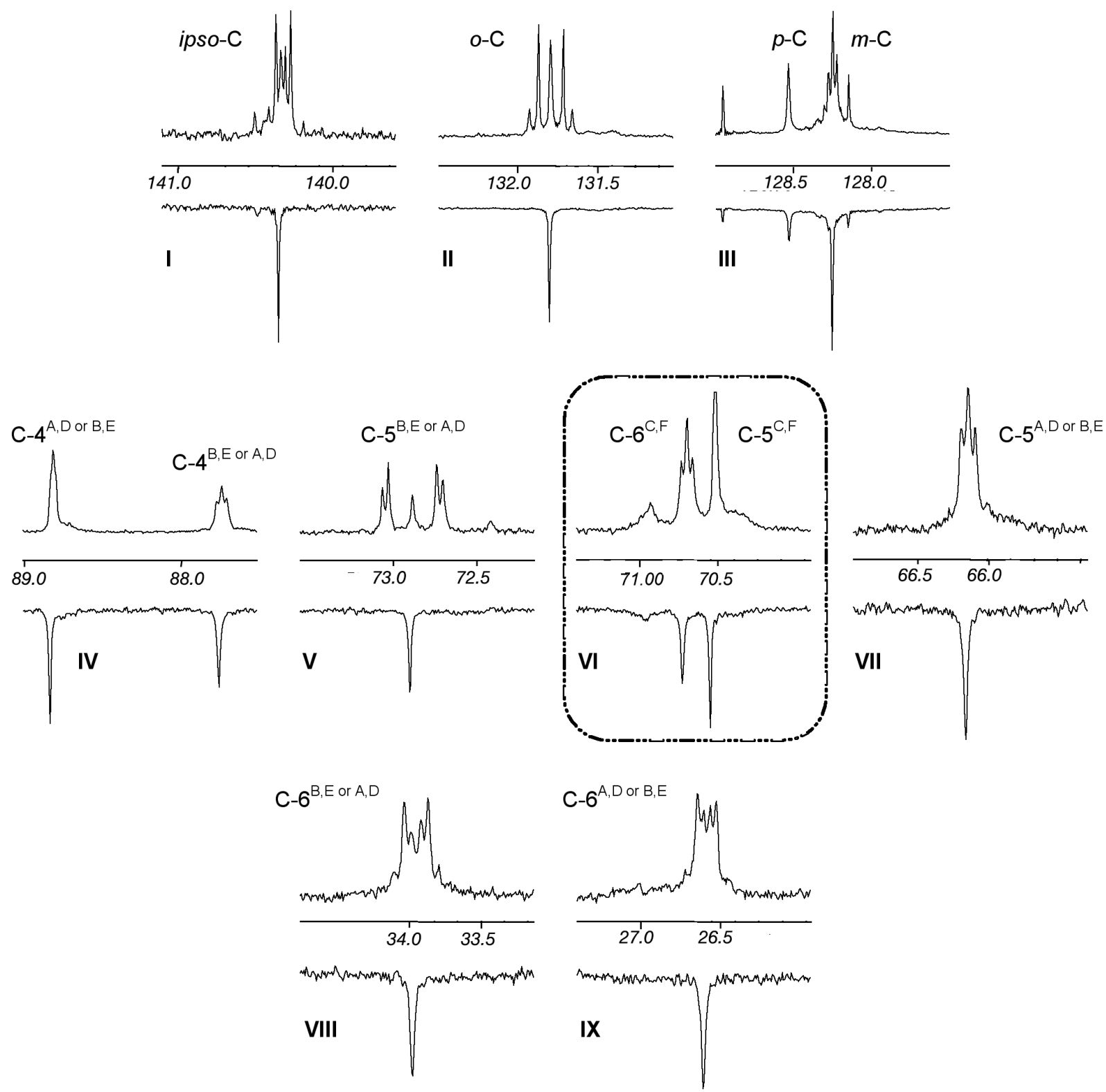

Figure SI2. Relevant signal enlargements of the ${ }^{13} \mathrm{C}\left\{{ }^{1} \mathrm{H}\right\}$ (upper parts) and ${ }^{13} \mathrm{C}\left\{{ }^{1} \mathrm{H},{ }^{31} \mathrm{P}\right\}$ (lower parts) NMR spectra of TRANSDIP recorded in $\mathrm{CDCl}_{3}$ at 125.8 $\mathrm{MHz}$. The $\mathrm{C}-6^{\mathrm{C}, \mathrm{F}}$ signal is singled out. 